\title{
Beyond the Iron Triangle: Implications for the Veterans Health Administration in an Uncertain Policy Environment
}

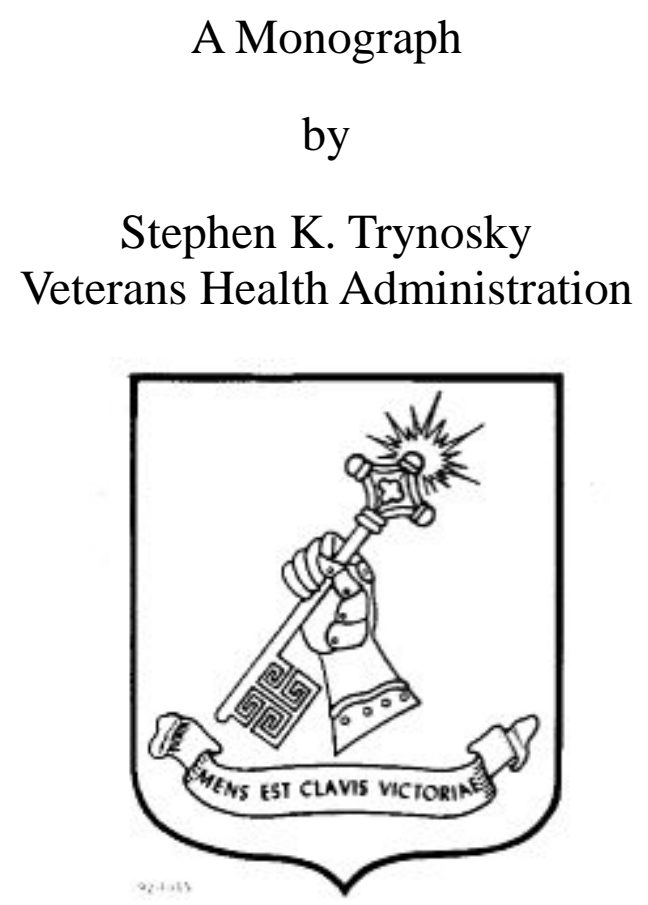

School of Advanced Military Studies

United States Army Command and General Staff College

Fort Leavenworth, Kansas

2014-02

Approved for public release; distribution is unlimited. 


\section{Monograph Approval Page}

Name of Candidate: Mr. Stephen K. Trynosky, GS-14

Monograph Title: Beyond the Iron Triangle: Implications for the Veterans Health

Administration in an Uncertain Policy Environment

Approved by:

, Monograph Director

Jeffrey Kubiak, PhD

, Seminar Leader

James MacGregor, COL

, Director, School of Advanced Military Studies

Henry A. Arnold III, COL

Accepted this $4^{\text {th }}$ day of December 2014 by:

Robert F. Baumann, PhD

, Director, Graduate Degree Programs

The opinions and conclusions expressed herein are those of the student author, and do not necessarily represent the views of the U.S. Army Command and General Staff College or any other governmental agency. (References to this study should include the foregoing statement.) 


\begin{abstract}
BEYOND THE IRON TRIANGLE: IMPLICATIONS FOR THE VETERANS HEALTH ADMINISTRATION IN AN UNCERTAIN POLICY ENVIRONMENT, by Stephen K. Trynosky, Veterans Health Administration, 90 pages.
\end{abstract}

The Department of Veterans Affairs is in the midst of a very serious crisis. The political and reputational fallout from the 2014 patient scheduling scandal exposed the further destabilization of the veterans' policy subgovernment consisting of VA, the congressional veterans' affairs committees, and large veterans' service organizations. This subgovernment, historically referred to as the "iron triangle," was among the most stable and insular domestic policy arenas in the six decades following World War II.

Since the 1990's a steady trend towards extreme partisan polarization has characterized both chambers of Congress. This dynamic gradually politicized an array of domestic policy realms. While veterans' policy was long immune to the worst of these trends, events during the 112th and 113th Congresses (2011-2015) illustrate the encroachment of partisan politicization into a once relatively nonpartisan issue area. This phenomenon was visible in both the Republican controlled House and the Democratic controlled Senate.

Simultaneous with the politicization of veterans' issues, the stature and influence of large veterans' service organizations such as the American Legion and VFW continue to decline. Although these groups were considered nearly invincible and achieved impressive legislative triumphs in the decades following World War II, events in the 113th Congress demonstrate their diminished power in a destabilized subgovernment. Inexorable demographic factors such as a declining veteran population and falling membership converge with the rise of narrowly focused veterans' advocacy groups that compete for public attention and finite philanthropy. The trends contributing to the decline of traditional VSOs were several decades in the making, but events throughout 2014 put these developments in stark relief.

The continued destabilization of the veterans' subgovernment has profound consequences for the Veterans Health Administration. Events throughout the 113th Congress suggest that VA failed to appreciate changes within the subgovernment and adapt accordingly. In the 114th Congress and beyond, VHA can anticipate the continuation of highly politicized congressional oversight while the influence of traditional VSOs continues to decline. Expanded calls for the further privatization of VHA services are expected and these efforts will be increasingly backed by corporate lobbying expenditures.

While VA itself cannot reverse trends affecting other elements of the veterans' subgovernment, it has options that can improve the effectiveness of its congressional outreach efforts and repair its severely damaged relationships with legislators and VSOs. It can also cultivate new surrogates to augment the traditional VSOs and reach expanded audiences from their unique perspectives.

Implementing the necessary institutional "shift in mind" to navigate this changed environment will not be easy for VHA, but the shared vision outlined by VA's new Secretary, Robert McDonald, shows much promise. As a leading health care organization, VHA is fundamentally a learning organization and can leverage many of the best cultural attributes that facilitated its medical care transformation in the 1990s to reevaluate its role within a destabilized and changing policy subgovernment. 


\section{Table of Contents}

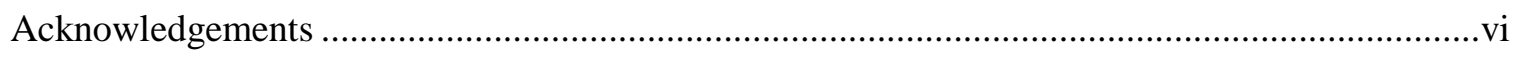

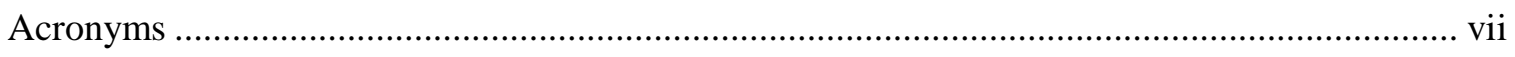

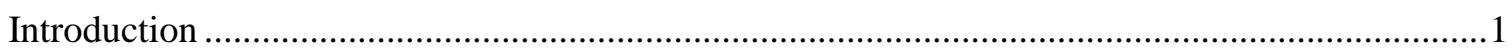

Part 1 The Veterans Policy Subgovernment...........................................................................6

Destabilizing Trends in the Congressional Landscape ..................................................... 9

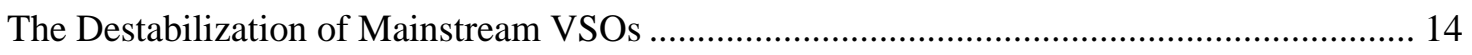

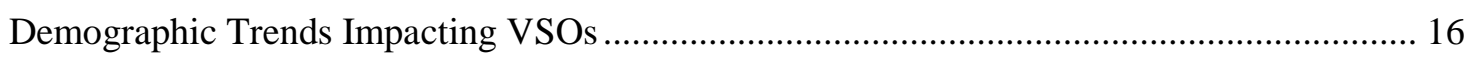

Consequences of Membership Trends on Traditional VSO Legislative Influence................... 18

The Rise of New Veterans Advocacy Groups and Their Impact on the Policy Debate............ 20

Part 2 The 113th Congress: The Accelerated Unravelling of the Veterans' Subgovernment ........24

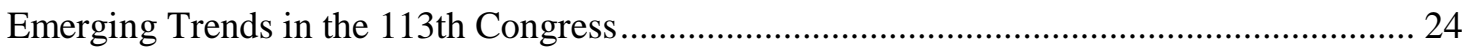

The House: Increased Oversight and Aggressiveness ...................................................... 26

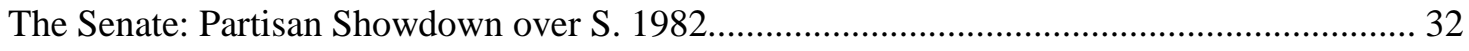

VHA’s 2014 Scheduling Scandal - Competing Priorities and Role Conflict.......................... 36

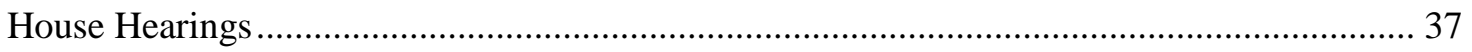

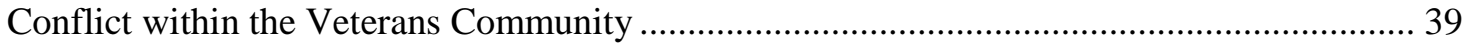

Veterans Reform Legislation - The Path to Public Law 113-146 ......................................... 41

Part 3 Strategic Implications of Veterans Subgovernment Destabilization for VHA ...................46

A Politically Charged Oversight Agenda Will Continue in the 114th Congress...................... 47

VSO Influence will Continue to Decline and Diminish Their Role as Third Party Surrogates 51 
The Increasing Geographic Disparity of America’s Veteran Population ............................... 52

Calls for Increased Privatization of VHA Services will Grow in Intensity ............................ 55

Part 4 Options for VHA in an Increasingly Unstable Policy Environment.................................59

Changing VA’s Traditionally Reactive Congressional Engagement Posture .......................... 62

Congressional Engagement Authority Can be Decentralized and Adaptability Fostered......... 67

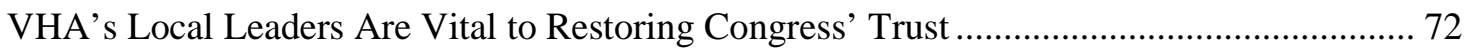

VHA Must Cultivate Other Third Party Surrogates to Supplement Declining VSOs .............. 77

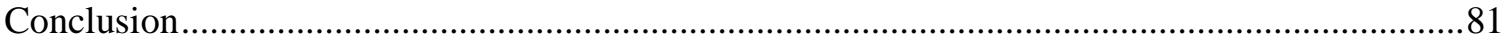

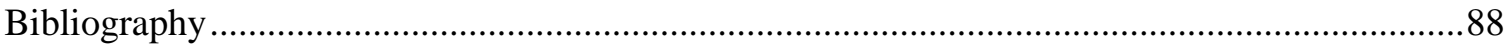




\section{Acknowledgements}

When I selected this monograph topic in February 2014, I could not have anticipated how dramatically the rest of the year would unfold for VA. I learned a tremendous amount about the veterans' policy subgovernment during the research and writing process and the experience was invaluable. I am especially grateful to VA for the unique opportunity to spend a year at Ft. Leavenworth reflecting on my previous experiences in VHA, DHS, and the Army while learning so much in the company of true professionals. This would not have been possible without the faith in my abilities that Crystal Ford, Ann Patterson, Dr. Lisa Thomas, and Dr. Robert Petzel, our former Under Secretary for Health, demonstrated in endorsing my application. I would further like to extend a special thanks to key individuals who took the time to help me develop this topic and refine my thoughts: David Ballenger, Phil Carter, Brandon Friedman, Mark Greenbaum, Glenn Johnson, Colonel John Kent, Dr. Larry Korb, Dr. Burdett Loomis, Dr. Thomas Mann, Mr. Rick Montgomery, Dan Moulton, Dr. Norman Ornstein, Dr. Bill Preston, Len Sistek, and Rick Weidman.

I am indebted to the men and women of the EPA Office of Inspector General Region VII field office in Lenexa, KS who made my wife feel so at home during our time at Fort Leavenworth.

Special thanks are in order to my monograph advisor, Dr. Jeff Kubiak and my two SAMS seminar leaders, Colonels John Paganini and James MacGregor, who showed great patience and support as I wrestled with this constantly evolving topic. Dr. William Gregor, the J. Lawton Collins Chair for Operational Art, was incredibly generous with his time and mentorship as this project neared completion.

Finally, I dedicate this modest effort to my wife Jill and my sons Stephen and Robert. Jill and Stephen took the leap of faith and followed me out to Kansas to participate in this unique opportunity. Despite the demanding workload at SAMS, we had many memorable experiences in the Kansas City area and beyond. The most incredible experience of all was the birth of Robert whose arrival coincided almost perfectly with the submission date for this project. 


\section{Acronyms}

AHA American Hospital Association

AMVETS American Veterans

AVF All-Volunteer Force

CBO Congressional Budget Office

CNN Cable News Network

CPC Congressional Progressive Caucus

CRS Congressional Research Service

CVA Concerned Veterans of America

DAV Disabled American Veterans

GAO Government Accountability Office

HAC House Committee on Appropriations

HCA Hospital Corporation of America

HELP Health, Education, Labor and Pensions

HVAC House Committee on Veterans’ Affairs

IAVA Iraq and Afghanistan Veterans of America

MILCON-VA Military Construction and Veterans’ Affairs

MOAA Military Officers Association of America

NCA National Cemetery Administration

OCLA Office of Congressional and Legislative Affairs

O\&I Oversight and Investigations 


\begin{tabular}{|c|c|}
\hline OEF & Operation Enduring Freedom \\
\hline OIF & Operation Iraqi Freedom \\
\hline OIG & Office of Inspector General \\
\hline OND & Operation New Dawn \\
\hline OSVA & Office of the Secretary of Veterans Affairs \\
\hline PAC & Political Action Committee \\
\hline PVAHCS & Phoenix VA Health Care System \\
\hline ROA & Reserve Officers Association \\
\hline SAC & Senate Committee on Appropriations \\
\hline SECVA & Secretary of Veterans Affairs \\
\hline SME & Subject Matter Expert \\
\hline SVAC & Senate Committee on Veterans’ Affairs \\
\hline USB & Under Secretary for Benefits \\
\hline USH & Under Secretary for Health \\
\hline VA & Department of Veterans Affairs \\
\hline VACO & VA Central Office \\
\hline VAMC & VA Medical Center \\
\hline VBA & Veterans Benefits Administration \\
\hline VFW & Veterans of Foreign War of the United States \\
\hline VHA & Veterans Health Administration \\
\hline VISN & Veterans Integrated Service Network \\
\hline
\end{tabular}


VHACO VHA Central Office

VSO Veterans Service Organization

WWII World War II

WWP Wounded Warrior Project 


\section{Introduction}

The Department of Veterans Affairs (VA) is in the midst of a very serious crisis. ${ }^{1}$ The political and reputational consequences from widespread patient scheduling improprieties puts VA in its most challenging situation in over a generation. ${ }^{2}$ Although the Veterans Health Administration (VHA) is the nation's largest integrated health care system and quietly developed a national reputation as a leader in health care innovation, quality, and cost containment, it seldom draws the focused attention of policy elites that other, more politically charged areas garner. ${ }^{3}$ Traditionally, veterans' issues are confined to a relatively closed network of policy experts, advocacy groups, and low profile congressional committees, collectively described as the “veterans’ subgovernment.”

The current environment for the veterans' subgovernment is quite different than it was even a few years ago. Beginning in 2011, Congress launched an uncharacteristically aggressive and coordinated oversight effort that accelerated in intensity throughout the 113th Congress (2013-2014). Media outlets largely sensationalized coverage of these oversight efforts, especially the 2014 patient scheduling scandal. ${ }^{4}$ In turn, many in Congress then amplified these troubling

\footnotetext{
${ }^{1}$ Letter from Secretary Robert McDonald and Acting Under Secretary for Health Carolyn Clancy to Acting Inspector General Richard Griffin, Department of Veterans Affairs, Office of Inspector General, Veterans Health Administration - Review of Alleged Patient Deaths, Patient Wait Times, and Scheduling Practices at the Phoenix VA Health Care System, August 26, 2014, accessed August 27, 2014, http://www.va.gov/oig/pubs/VAOIG-14-02603-267.pdf.

2 Sloan D. Gibson, "Remarks of Acting Secretary Sloan D. Gibson During VFW Annual Convention" (address at the $115^{\text {th }}$ VFW Annual Meeting, St. Louis, MO, July 22, 2014), accessed July 27, 2014, http://www.va.gov/opa/pressrel/pressrelease.cfm?id=2588.

${ }^{3}$ Kenneth W. Kizer and R. Adams Dudley, "Extreme Makeover: Transformation of the Veterans Health Care System,” Annual Review of Public Health 30 (2009): 18.1-18.27.

${ }^{4}$ Glenn Kessler, author of The Washington Post's Fact Checker series, examined allegations made by elected officials and media figures following the 2014 discovery of systemic and inappropriate scheduling practices at VA medical centers. Kessler found that a number of the widely reported allegations attributed veteran deaths to wait times without sufficient evidence to support those claims. Glenn Kessler, "Overblown Claims of Deaths and Waiting Times at the VA,” Washington Post, September 2, 2014, accessed September 7, 2014,
} 
reports and used them as a vehicle to tie issues of VA accountability and safety to broader policy arguments far beyond the crisis itself and into an ideological battle over the proper role of government. This dynamic generated enormous public interest and catalyzed the still-unfolding chain of events that led to the resignation of the longest serving Secretary of Veterans Affairs, ${ }^{5}$ renewed calls for the privatization of VA health care programs, ${ }^{6}$ and passage of legislation that, among other things, curtailed the due process rights of senior VA employees. ${ }^{7}$ The recent serious allegations against VA and heightened congressional scrutiny into VHA's day-to-day operations exposed further changes to the traditional veterans’ policy subgovernment that coalesced at the end of World War II and functioned with relative stability for over five decades. ${ }^{8}$

This monograph will explore the ongoing political and demographic trends destabilizing the traditional veterans’ policy subgovernment at the Federal level and the likely consequences for VHA. This destabilization has occurred on two primary axes of the veterans' subgovernment: in the congressional committees with jurisdiction over VA and the large veterans service organizations (VSOs) such as the American Legion and Veterans of Foreign War (VFW). In the first instance, congressional partisanship increasingly influences the arena of veterans' affairs, an issue that largely escaped the modern phenomenon of political polarization even during the last

http://www.washingtonpost.com/blogs/fact-checker/wp/2014/09/02/overblown-claims-of-deathsand-waiting-times-at-the-va/.

${ }^{5}$ Patricia Kime, “VA Secretary Shinseki Resigns,” Federal Times, May 30, 2014, accessed June 23, 2014, http://www.federaltimes.com/article/20140530/AGENCY02/305300008/VA-Secretary-Shinsekiresigns.

${ }^{6}$ Michael D. Shear, and Jonathan Weisman, "Veteran Scandal Aggravates Woes of White House,” New York Times, May 21, 2013, A1.

${ }^{7}$ Joe Davidson, "For VA to be Veteran-Centric, it Also Needs to be EmployeeAttentive,” Washington Post, September 9, 2014, accessed September 10, 2014, http://www.washingtonpost.com/politics/federal_government/for-va-to-be-veteran-centric-it-alsoneeds-to-be-employee-attentive/2014/09/09/f6fed452-3856-11e4-9c9f-ebb47272e40e_story.html.

${ }^{8}$ Paul C. Light, Forging Legislation (New York: W.W. Norton \& Company, 1992), 5. 
two decades of partisan strife as it buffeted other policy communities. ${ }^{9}$ Secondly, the traditional veterans’ advocacy and service organizations that played outsized roles in the legislative and policy victories for veterans since World War II face acute membership challenges and diminished political influence. Their waning power to shape congressional policy priorities was evident throughout the 113th Congress (2013-2014) and it shows every indication of continuing.

To be clear, these trends were well underway before the recent scheduling scandal captured the nation's attention in May 2014, but the contours of this destabilization were subtle and imperceptible to many. ${ }^{10}$ Until very recently, only a handful of scholarly studies had even examined the modern interplay of veterans' issues in the larger political universe. ${ }^{11}$ This left the comprehensive understanding of changes to this subgovernment badly neglected and confined to

${ }^{9}$ Tom Philpott a widely published writer on veterans' policy recently observed that, “in my 37 years covering veterans' issues, I have never seen veteran issues used more cynically or politicized more thoroughly than during the past several years." Tom Philpott, "Vets Should be Wary of CVA Pitchforks and Torches," Stars and Stripes, May 23, 2014, accessed September 11, 2014, http://www.stripes.com/opinion/vets-should-be-wary-of-cva-pitchforks-and-torches1.284769 .

${ }^{10}$ VA senior leaders were not alone in missing many of these trends. The media coverage surrounding the scheduling crisis presumed a dynamic within the veterans' subgovernment that no longer existed, namely the overwhelming political influence of veterans' service organizations on congressional and agency decision making. For examples of authors who likely overstate the influence of VSOs in 2014, see Yuval Levin, “The Veterans Affairs Scandal," National Review Online, May 30, 2014, accessed June 14, 2014, http://www.nationalreview.com/node/379141; Donald Devine, “The VA's Bureaucracy Always Wins - Until Now,” The American Conservative, June 4, 2014, accessed June 14, 2014, http://www.theamericanconservative.com/the-vas-bureaucracy-always-wins-until-now/.

${ }^{11}$ Suzanne Mettler, foreword to Veterans’ Policies, Veterans Politics: New Perspectives on Veterans in the Modern United States, ed. Stephen R. Ortiz (Gainesville, FL: University Press of Florida, 2012), xi. 
the small group actively engaged in veteran policy issues, as veterans’ affairs has long been an area seldom covered by mass media ${ }^{12}$ or even the focus of intense congressional attention. ${ }^{13}$

These developments within the veterans' subgovernment are relevant for VHA because their combined impact has fundamentally altered the relatively stable policy environment it occupied throughout the post-World War II era and that had nurtured VHA's emergence as an innovative leader in health care. As events during the current 113th Congress demonstrate, VA can no longer assume default support for its program priorities from its congressional committees of jurisdiction; nor can it assume that the large VSOs will uniformly be willing or able to serve as effective surrogates or legislative shepherds on its behalf to Congress or the larger public. ${ }^{14}$

12 Damian Paletta of The Wall Street Journal perhaps best described coverage of VA in mass media when he said, "[VA] is one of those agencies that doesn't get a lot of attention unless something bad happens.” Damian Paletta, Wall Street Journal, Economic Policy Reporter, interview by Pedro Echevarria, C-SPAN Washington Journal, June 7, 2014, accessed September 7, 2014, http://www.c-span.org/video/?319633-6/washington-journal-veterans-affairs-healthservices.

${ }^{13}$ In a conversation with the author, Dr. Burdett Loomis, a University of Kansas Professor of Political Science in Lawrence, KS on February 12, 2014, Dr. Burdett Loomis explained that within the political science community the study of veterans' issues is very specialized and actively followed by a relative handful of academics.

${ }^{14}$ The primary congressional authorizing committees for VA are the House Committee on Veterans' Affairs (HVAC) and the Senate Committee on Veterans' Affairs (SVAC). Members of the veterans' subgovernment colloquially refer to the majority and minority of these committees as "The Four Corners." The primary appropriations subcommittees for VA are the House Committee on Appropriations, Subcommittee on Military Construction, Veterans Affairs and Related Agencies (MILCON-VA); and the Senate Committee on Appropriations, Subcommittee on MILCON-VA. The majorities and minorities of VA's primary authorizing committees and appropriations subcommittees are collectively called "The Eight Corners." From time to time, other congressional committees have jurisdiction over VA programs and elect to exercise that jurisdiction. In recent years, the following committees have called VA witnesses to testify at their hearings: House Committee on Armed Services; House Committee on Oversight and Government Reform; House Committee on Science \& Technology; Senate Committee on Armed Services; Senate Committee on Health, Education, Labor and Pensions; Senate Committee on Homeland Security and Governmental Affairs; and the Senate Committee on Indian Affairs (note: this listing is not exhaustive). 
Collectively, these trends suggest that a fundamental reordering of one of the most stable and enduring domestic policy subgovernments is well underway. ${ }^{15}$

For better or for worse, the traditional bipartisan congressional approach to veterans’ issues and the formidable power of large VSOs insulated VA from political trends that severely impacted almost all other Executive branch agencies beginning with the Reagan administration; these impacts included competitive sourcing (privatization), reduced budgets, and cuts to the Federal workforce. ${ }^{16}$ This protective cocoon may have left VA leaders unprepared to appropriately alter their traditionally reactive approach to congressional affairs and media outreach once the prevailing culture of comity disappeared within the subgovernment and it assumed the traits of more politicized domestic policy issue areas.

To adapt to the ongoing destabilization of its policy subgovernment, VA must fundamentally alter its interaction with congressional stakeholders, VSOs, and the American public. Most importantly, to better navigate the new domestic policy environment that seems to have cemented itself in the 113th Congress, the Department must build relationships and develop champions and stakeholders beyond the narrow sliver of Congress it traditionally focused on. As the veteran population disproportionately declines in some regions and the political influence of VSOs unevenly wanes throughout the country, VA must build and sustain support for its mission among congressional stakeholders just as other Federal agencies have learned to operate in recent decades (e.g. the individual military services and the Department of Homeland Security). It cannot continue to assume that other organizations, no matter how venerable or well intended,

${ }^{15}$ In a telephone conversation with the author on September 3, 2014, Dr. Norman Ornstein, Resident Scholar with the American Enterprise Institute, explained that VA was long insulated from polarizing trends within Congress because of the nature of its mission, serving veterans. He added that once VA found itself in the crossfire of modern congressional politics following the patient scheduling crisis, almost no one was prepared to deal with it.

${ }^{16}$ Paul C. Light, Forging Legislation, 6. 
will have the desire or ability to "tell the VA story" in all 50 states and 435 congressional districts.

Against this contextual backdrop, this monograph will first explore the origins and structure of the traditional veterans' policy subgovernment, then expand its focus to broadly identify its destabilization trends through two lenses: Congress and the traditional VSO community. The acceleration of these trends throughout the 113th Congress will be closely examined with a special focus placed on the party-line filibuster of Senate Bill 1982 (S. 1982) in February 2014, the largest piece of proposed comprehensive veterans legislation in decades. A discussion of the veteran policy subgovernment's response to the unfolding patient scheduling crisis will follow. Finally, this research concludes with the identification and discussion of the long-term implications for VA as well as possible options to mitigate the effects of subgovernment destabilization.

\section{Part 1}

\section{The Veterans Policy Subgovernment}

A domestic policy subgovernment is traditionally comprised of a Federal agency in the executive branch, a committed group of congressional stakeholders, associations representing the agency's clientele, and a fairly homogenous constituency. ${ }^{17}$ Central to this structural organization is the idea that an agency seeks to develop a strong relationship with politically active members or groups that share the same general goals or interests. ${ }^{18}$ The components of the subgovernment leverage these constituent relationships to expand political influence and increase support for

${ }^{17}$ Stephen E. Frantzich and Claude Berube, Congress: Games and Strategies, $4^{\text {th }}$ ed. (Lanham, MD: Roman and Littlefield, 2010), 308.

${ }^{18}$ Max A. Bergmann, “The Impact of Veterans on the American Political System," in Serving America's Veterans: A Reference Handbook, ed. Lawrence J. Korb, Sean E. Duggan, Peter M. Juul, and Max A. Bergmann (Santa Barbara, CA: ABC-CLIO, LLC, 2009), 55. 
programs and policy preferences. For their part, outside interest groups serve as third party advocates to Congress for agency priorities and further provide political or electoral support in return for support on key issues. ${ }^{19}$

The long recognized veterans' subgovernment is composed of over forty veterans’ organizations, the Veterans' Affairs committees in the House and the Senate, and the Department of Veterans Affairs. ${ }^{20}$ Political scientists frequently used the veterans' subgovernment as a textbook example of an "iron triangle," the most closed type of subgovernment comprised of a Federal agency, Congress, and powerful interest groups; though that term is no longer fashionable in most political science literature. ${ }^{21}$ It continually proved its effectiveness in the decades following the end of the Second World War by winning billions in benefits for its constituents while continually achieving increased VA budgets with broad support. ${ }^{22}$ These legislative and policy victories were consistently achieved even during recent periods of divided government and heightened partisan conflict. ${ }^{23}$ Phillip Longman, a health policy expert with the New America Foundation, asserts that the strength and cohesiveness of the veterans' subgovernment is probably the only reason that VHA's unique health care system survived into the 21 st century. ${ }^{24}$

${ }^{19}$ Max A. Bergmann, “The Impact of Veterans on the American Political System,” 55.

${ }^{20}$ Lance deHaven-Smith, and Carl E. Van Horn, "Subgovernment Conflict in Public Policy,” Policy Studies Journal 12, no. 4 (June 1984): 631.

${ }^{21}$ James Q. Wilson Jr., John J. DiIulio, and Meena Bose, American Government: Brief Version, $11^{\text {th }}$ ed. (Boston: Cengage Learning, 2013), 305-306.

22 Stephen E. Frantzich and Claude Berube, Congress: Games and Strategies, 324-325.

${ }^{23}$ Events during the Clinton administration are illustrative of the phenomenon where veterans' issues were exempt from the polarizing trends in Congress that impacted other policy arenas. While Republicans who controlled the House and Senate often united to oppose most major Clinton initiatives, they supported and passed several pieces of comprehensive veterans' legislation championed by the President. See La Triece M. Washington, The Veteran's Millennium Health Care Act of 1999: A Case Study of Role Orientations of Legislators, the President, and Interest Groups, (Dallas: University Press of America, 2003), 2.

${ }^{24}$ Phillip Longman, Best Care Anywhere: Why VA Health Care Would Work Better for Everyone, $3^{\text {rd }}$ ed. (San Francisco: Berrett-Koehler Publishers, Inc., 2012), 21. 
The stability of the post-WWII veterans' subgovernment was built on a congressional culture of bipartisanship and weak party system that provided committee chairmen with relative autonomy from their party leadership and great latitude to collaborate across the aisle for compromise without fear of electoral or intra-caucus repercussions. The bedrock notion of weak parties and bipartisan approaches to policy problems was so foundational and enduring that materials prepared in 1992 for use in leadership training programs for Federal employees declaratively stated that "few votes on policy issues of either House of the Congress are along party lines.” ${ }^{25}$ Within a very short period of time, this notion would be completely upended in Congress by several factors, most notably the changes ushered into the House by Speaker Newt Gingrich following the 1994 elections; ${ }^{26}$ over time these trends gradually migrated to the Senate. ${ }^{27}$

It is difficult to overstate the tremendous influence the mainstream VSOs wielded during the six decades following World War II. Even during periods of shrinking government and privatization, VA grew to an agency of "almost unimaginable size and scope” because of the tremendous influence of the large VSOs. ${ }^{28}$ The symbiotic relationship between these organizations and VA led one observer to comment that by 1987 it was almost impossible to tell where the VA ended and VSOs began. ${ }^{29}$ Staff from VSOs routinely rotated through positions within VA and the congressional committees responsible for its oversight thus solidifying the

${ }^{25}$ Daniel M. Ogden Jr., How National Policy is Made, $4^{\text {th }}$ ed. (D.M. Ogden, Jr: 1992), 1.

${ }^{26}$ Richard Pildes, "Why the Center Does Not Hold: The Causes of Hyperpolarized Democracy in America, California Law Review 99, no. 2 (April 2011): 319-320.

${ }^{27}$ Sean Theriault, The Gingrich Senators (New York: Oxford University Press, 2013), $11-13$.

${ }^{28}$ Paul C. Light, Forging Legislation, 6.

${ }^{29}$ Janet Frantz, “The Battle Over America’s VA Hospitals,” Politics \& Policy 30, no. 3 (September 2002): 532. 
strength of the subgovernment. ${ }^{30}$ In the House of Representatives, VSO support for legislation was often a sufficient imprimatur to assure unanimous or near-unanimous passage. ${ }^{31}$

Destabilizing Trends in the Congressional Landscape

VA’s primary congressional committees of jurisdiction, the House Committee on Veterans’ Affairs (HVAC) and the Senate Committee on Veterans' Affairs (SVAC), are considered low-prestige assignments within the congressional committee hierarchy. ${ }^{32}$ Paradoxically, the low media and political profile of HVAC and SVAC historically gave their chairmen wide latitude to influence the discrete sets of policy issues concerning veterans. This insularity and autonomy helped foster the strong post-WWII veterans’ policy subgovernment. ${ }^{33}$ The HVAC (established in 1947) and the SVAC (1971) ${ }^{34}$ have differed throughout the modern congressional era despite sharing complementary jurisdiction over VA. ${ }^{35}$ Aided by forty years of unbroken Democratic control (1955-1995), HVAC was long helmed by a series of strong conservative Democrats, principally from the South. These long-serving chairmen, particularly Rep. Sonny Montgomery (D-MS), who headed the committee from 1981 through 1995, ruled with a firm hand and accrued a level of influence and power over policy matters that few other chairmen shared. ${ }^{36}$ The stability of HVAC’s membership and staff created a hospitable culture

${ }^{30}$ Bill Keller, “How a Unique Lobby Force Protects Over \$21 Billion In Vast Veterans' Programs,” Congressional Quarterly Weekly, June 14, 1980, 1630-1631.

${ }^{31}$ David W. Rohde, "Parties and Committees in the House: Member Motivations, Issues, and Institutional Arrangements,” Legislative Studies Quarterly 19, no. 3 (August 1994): 353.

${ }^{32}$ Ryan Grim, “Here’s the Simple Reason Congress Hasn’t Fixed the VA,” The Huffington Post, June 5, 2014, accessed June 14, 2014, http://www.huffingtonpost.com/2014/06/04/va-scandal_n_5446977.html.

33 Bill Keller, “How a Unique Lobby Force Protects Over \$21 Billion In Vast Veterans’ Programs,” 1627.

${ }^{34}$ Ibid.

${ }^{35}$ Max A. Bergmann, “The Impact of Veterans on the American Political System,” 73-74.

${ }^{36}$ Max A. Bergmann, “The Impact of Veterans on the American Political System,” 73-74. 
that the VSOs generally preferred to work with. ${ }^{37}$ For these and other reasons, the HVAC was traditionally seen as more responsive to VSOs and their constituent concerns than the Senate. ${ }^{38}$

In most instances, congressional committees are traditionally populated by “policy outliers," those members with the highest stake in a given policy area who become active leaders on those issues. ${ }^{39}$ However, this model is not necessarily applicable to HVAC, because few Members seek to serve on it and even fewer elect to remain on it as they accrue seniority and become eligible to serve on more choice committees. This is not a recent phenomenon and the paucity of senior members gives the committee little access to congressional leadership, media outlets, the White House, or the various other levers of power in Washington. ${ }^{40}$

For example, even during the heyday of the veterans’ subgovernment's “iron triangle” era during the 87th through 97th Congresses (1961-1983), only 24 Democratic freshmen even requested assignment to HVAC, yet three times that number were assigned to the committee most involuntarily. ${ }^{41}$ More recently, between the 104th and 112th Congresses (1995-2013), while 16 incumbent House Members requested reassignment to HVAC, 50 others requested to leave. ${ }^{42}$ This ratio of arrivals to departures is but one small metric for evaluating a committee's value in the eyes of Members, but is nonetheless deeply revealing. Generally, the fundraising potential for service on HVAC is extremely limited and this contributes to a high rate of turnover as Members

${ }^{37}$ Bill Keller, “House and Senate Veterans' Panels ...As Different as 'Night and Day,'” Congressional Quarterly Weekly, June 14, 1980, 1630-1631.

${ }^{38}$ Paul C. Light, Forging Legislation. 35.

${ }^{39}$ Gary W. Cox and Matthew D. McCubbins, Legislative Leviathan: Party Government in the House (Berkeley: University of California Press, 1993), 12.

${ }^{40}$ Ryan Grim, “Here’s the Simple Reason Congress Hasn’t Fixed The VA.”

${ }^{41}$ Gary W. Cox and Matthew D. McCubbins, Legislative Leviathan: Party Government in the House, 38-39.

${ }^{42}$ Lee Drutman, "Ways and Means, Financial Services, and Energy and Commerce are Top House Fundraising Committees,” Sunlight Foundation (blog), June 2, 2012, accessed September 5, 2014, http://sunlightfoundation.com/blog/2012/04/02/housecommittees/. 
seek more advantageous panels to raise money. The Sunlight Foundation estimates that service on HVAC actually penalizes Members in their fundraising ability, as opposed to representatives who sit on other committees. ${ }^{43}$

In contrast to HVAC, the SVAC chairmanship changed hands far more frequently throughout its shorter history, resulting in less direct influence in the development of VA policy. ${ }^{44}$ The nature of Senate committees differs from the House and the SVAC is no exception. For example, senators serve on more committees than House Members and have even more competing demands for their limited time. ${ }^{45}$ While the individual senators on SVAC have much higher profiles than most HVAC Members, they can devote considerably less time to committee and veterans' issues and their membership alone does not raise the panel's overall prestige. ${ }^{46}$ SVAC is one of the least active committees in Congress based on the number of hearings held. ${ }^{47}$ It has no subcommittees and held only 11 hearings with VA witnesses during 2013 and 7 in 2014 (through September 15, 2014). ${ }^{48}$ SVAC’s structural limitations and resource challenges are especially evident in 2014 because the VHA patient scheduling crisis pre-empted virtually all

${ }^{43}$ Lee Drutman, “Ways and Means, Financial Services, and Energy and Commerce are Top House Fundraising Committees.”

${ }^{44}$ Bill Keller, "House and Senate Veterans' Panels ... As Different as 'Night and Day.'”

${ }^{45}$ Within the Senate hierarchy, SVAC is classified as a minor committee. Senators generally serve on two major committees in addition to a handful of minor committees. James Q. Wilson Jr., John J. DiIulio, and Meena Bose, American Government: Brief Version, 228-230.

${ }^{46}$ In recent years, senators averaged 3.9 committee assignments and 8.1 subcommittee assignments. These demands in conjunction with fundraising obligations force them to operate under severe time pressures. Barbara Sinclair, Unorthodox Lawmaking: New Legislative Processes in the U.S. Congress, $4^{\text {th }}$ ed. (Washington, DC: CQ Press, 2012), 53.

${ }^{47}$ Senator Tom Coburn (R-OK), Oversight Report: Friendly Fire - Death, Delay \& Dismay at the VA, June 11, 2014, accessed August 31, 2014, http://www.coburn.senate.gov/public/index.cfm/2014/6/beyond-the-waiting-lists-new-senatereport-reveals-a-culture-of-crime-cover-up-and-coercion-within-the-va.

${ }^{48}$ SVAC regularly holds a series of hearings where VSO witnesses present their legislative priorities, but these do not include VA witnesses nor do they provide an opportunity for indirect oversight. See "Hearings," U.S. Senate Committee on Veterans' Affairs, accessed September 12, 2014, http://www.veterans.senate.gov/hearings?PageNum_rs=1\&. 
committee hearings on non-VHA topics. In turn, the committee holds little esteem within the chamber: the Congressional Research Service reported that SVAC had the second lowest staff budget in the Senate. It also lacks its own press office - one of the extremely few standing committees in all of Congress to operate without a press media staff - a limitation that significantly hampers its ability to influence media and craft an overall narrative for the committee’s activities. ${ }^{49}$

The political dynamics for veterans' issues and the powerful clout of VSOs began to change as the 21st Century approached. When Republicans gained control of the House of Representatives following the 1994 elections, the new majority instituted a sweeping series of changes in the rules governing the internal operation of the chamber. These measures significantly reversed the Watergate-era reforms designed to reinvigorate and re-empower committees to become more productive and responsive to both Members and outside interests. ${ }^{50}$ From 1995 onward, the House leadership increasingly consolidated power. Consequently, more legislative initiatives and priorities began circulating first in leadership offices before being forced down onto the committees, instead of allowing legislation to originate organically at the committee level. Initially, this impacted some committees more than others. The House Veterans' Affairs Committee, widely regarded as a legislative backwater, was not subject to this level of partisan meddling and remained an oasis of relatively genteel bipartisanship for nearly a decade after the Gingrich-era House rules were adopted. VSOs and committee members continued to comprise a largely closed, but effective subgovernment. Indeed, the tally of legislative wins throughout the Clinton administration on behalf of veterans is remarkable testament to the

\footnotetext{
${ }^{49}$ Ryan Grim, “Here’s the Simple Reason Congress Hasn’t Fixed The VA.”

50 "House Enacts Rule Changes ... Strengthens GOP Leadership’s Hand,” Congressional Quarterly Almanac, $104^{\text {th }}$ Congress $1^{\text {st }}$ Session ... 1995, Volume LI (Washington DC: Congressional Quarterly Inc., 1996), 1-12-13.
} 
efficacy of the working relationships between VSOs, congressional advocates of both parties, and VA that endured over this period. ${ }^{51}$

A string of Clinton-era legislative victories accrued expanded benefits for veterans and provided VA with increased flexibility and authority to implement its programs, particularly through expanded veteran eligibility to VHA health care. These moves, while credited for VA's emergence as a national health care leader, ${ }^{52}$ came with significant budgetary costs, earning the ire of many conservatives. Following the 2000 elections, the Bush White House and Republican congressional leadership began to demonstrate greater interest in the workings of the HVAC and the actions of its Chairman, Rep. Christopher Smith (R-NJ), because they bristled at the rising costs of legislation approved by the committee. Despite pressure from within his party to change course, Rep. Smith continued to work with VSOs and Democrats in an attempt to set VA funding as a mandatory (entitlement) program, thus removing it from yearly budget battles. ${ }^{53}$ This effort infuriated House leadership who stripped Smith of his chairmanship in 2005, replacing him with the more politically reliable, Rep. Steve Buyer (R-IN). This move by congressional leadership signaled a willingness to weaken the autonomy of congressional committees within the realm of veterans’ affairs. After Rep. Smith’s ouster, committee members were on notice: House leadership would not tolerate collaboration with VSOs on legislative priorities at variance with their preferences. ${ }^{54}$ of 1999.

${ }^{51}$ See Generally, La Triece M. Washington, The Veteran’s Millennium Health Care Act

${ }^{52}$ Said C. Ibrahim, David S. Macpherson, and Michael E. Moreland, "VA Healthcare System: A Potential Model for a National Plan,” in The Praeger Handbook of Veterans' Health: History, Challenges, Issues, and Developments, ed. Thomas W. Miller, vol. 4., Future Directions in Veterans' Healthcare (Santa Barbara, CA: Praeger, 2012), 167-168.

${ }^{53}$ Mark Greenbaum, “NJ Rep. Chris Smith’s Fight for VA Was Ahead of Its Time,” Newark Star Ledger, June 5, 2014, accessed June 9, 2014, http://www.nj.com/opinion/index.ssf/2014/06/nj_rep_chris_smiths_fight_for_va_was_ahead_of_i ts_time_opinion.html.

${ }^{54}$ Mark Greenbaum, “NJ Rep. Chris Smith’s Fight for VA Was Ahead of Its Time,” 
The removal of Chairman Smith's gavel on HVAC may have had a chilling effect on the development of some sweeping, aspirational legislation, but large scale and expensive veterans’ legislation continued to become law during the Bush administration, even during the 2007-2009 era of divided government. The high profile enactment of the Post-9/11 Veterans Assistance Act of 2008 is testament to this dynamic. Although the Bush Administration initially opposed expanded GI Bill benefits on grounds that their generosity might adversely impact retention of military personnel during a time of war, a bipartisan effort emerged in the Senate to push for its passage. The traditional VSOs expended tremendous political capital on this effort and they were joined by newer veterans’ organizations such as the Iraq and Afghanistan Veterans of America (IAVA). The IAVA employed a novel advocacy strategy for veterans’ benefits that partially bypassed the normal congressional committee structure by appealing directly to individual legislators and using media and surrogates to make a moral appeal to national thought leaders and the general public. ${ }^{55}$

The Destabilization of Mainstream VSOs

In the five decades following World War II, the large VSOs were a powerful component of the veterans' subgovernment. Through their growing membership, that ballooned with the large cohort of World War II veterans, and expanded influence at all levels of government in the form of vigorous advocacy, VSOs secured great gains for their constituents, VA programs, and veterans broadly. Students of the American political system generally consider the passage of the GI Bill of Rights in 1944 as the starting point for the VSOs’ ascendency as politically powerful actors. ${ }^{56}$ When Congress began considering the underlying bill, Members approached the

${ }^{55}$ Melinda R. Tarsi, "From Rights to Repayments: The Framing of the Post-9/11 GI Bill” (paper presented at the 2011 American Political Science Association Annual Conference, Seattle, WA, September 1-4, 2011), accessed June 11, 2014, http://papers.ssrn.com/sol3/papers.cfm?abstract_id=1900991.

56 Theda Skocpol, Diminished Democracy: From Membership to Management in 
American Legion and requested its help in formulating a legislative strategy for the measure’s passage. ${ }^{57}$ The Legion's organizational support was pivotal to crafting and passing the bill (it even supplied the name) and this success was critical too in establishing the American Legion as one of the "most politically consequential organizations of the twentieth century." 58 With the Legion, other VSOs would quickly join in exerting outsized political influence in the ensuing decades.

Throughout the postwar era, political observers characterized groups like the American Legion, VFW, and Disabled American Veterans (DAV) as “invincible” on Capitol Hill and the congressional veterans' committees readily acknowledged that they rarely did anything that VSOs were collectively opposed to. ${ }^{59}$ This tremendous political clout persisted throughout the 1990s even as VSO membership began its steady decline and Congress, particularly the House, was gripped by emerging bitter partisan divides. During the Clinton administration, an era of deeply divided government, VA was essentially immune to the budgetary and political pressures that reduced the programs and workforce in most Federal agencies. ${ }^{60}$ Media accounts at the time attributed much of VA's success in dodging these cuts to the enduring political power of VSOs that pushed through legislation to exempt VA from most of the government-wide staff cuts mandated under President Clinton’s initiative to “reinvent government.”61

American Civic Life (Norman, OK: University of Oklahoma Press, 2003), 71.

${ }^{57}$ Nancy Beck Young, "Do Something for the Soldier Boys: Congress, the G.I. Bill of Rights, and the Contours of Liberalism," in Veterans Policies, Veterans Politics: New Perspectives on Veterans in the United States, ed. Stephen R. Ortiz (Gainesville, FL: University Press of Florida, 2012), 207.

${ }^{58}$ Alec Campbell, “The Sociopolitical Origins of the American Legion,” Theory \& Society 39, no. 1 (2010): 1. Programs.”

${ }^{59}$ Bill Keller, “How a Unique Lobby Force Protects Over \$21 Billion In Vast Veterans’

${ }^{60}$ Bill McAllister, "VA Hospitals Impervious to Budget Knife; Treating Fewer Patients, VA Hospitals Defy Gravity of Budget Cuts,” Washington Post, May 21, 1995, A1.

${ }^{61}$ David Masci, “Cuts All Over - Except the VA,” Congressional Quarterly, July 15, 1995, 2067. 
Just as post-1994 trends broadly outlined in the previous section destabilized the congressional pillar of the veterans' subgovernment, a number of comparable trends have afflicted the VSO pillar as well. The most salient trends include: 1) dramatic veteran demographic trends impacting VSO membership levels; 2) a steady erosion of influence in congressional policy debates on VA missions and programs; and 3) the rise of newer, narrowly focused veteran advocacy groups that aggressively compete for public attention and threaten once reliable fundraising and revenue streams. A detailed discussion of each of these phenomena follows.

\section{Demographic Trends Impacting VSOs}

Today, traditional VSOs face significant membership challenges due primarily to the changing demographics of America's veteran population. More than forty years have passed since the U.S. transitioned from a hybrid volunteer-draftee force structure to its current recruiting model that is dependent on relatively lengthy enlistments from a smaller number of volunteers. With a smaller military and fewer Americans serving in uniform, the universe of potential VSO members has steadily declined as older veterans pass away. These demographic shifts, beyond the control of any organization's strategic planning, have impacted the political influence VSOs can exert. While they are certainly influential in the realm of veterans’ policy, events during the 113th Congress have exposed the very real limits they face in swaying Congress on priority issues.

The membership trends of the VFW, the nation's second largest veterans organization, usefully illustrate the current plight of the mainline VSOs. ${ }^{62}$ At the end of 2013, the VFW

62 The American Legion faces comparable membership challenges as the VFW, although these may be mitigated somewhat by its less stringent membership criteria. The Legion claimed less than 2.4 million members in 2012, an 11 percent decline from 2000. During the same period, it shuttered nearly 1,000 of its posts. Despite these trends, the organization set an ambitious goal of reaching 3 million members in 2019 in time for its $100^{\text {th }}$ anniversary. Most of America's living veterans are eligible for American Legion membership. See Karen Ann Cullotta, “An Aging American Legion Fights for Relevancy,” The New York Times, March 17, 2013, A17. 
claimed approximately 1.3 million members ${ }^{63}$ down from 2.1 million in 1992 (the postwar peak of VFW membership). ${ }^{64}$ Tellingly, of the current membership, only $17 \%$ are veterans of postVietnam conflicts. ${ }^{65}$ As a result, unless VFW can reverse current member trends, its projected headcount will fall to 1.2 million by 2018. ${ }^{66}$ In 2013, VFW Adjutant General Allen Kent conceded that he does not see any way the organization can stay above 1 million members unless the United States becomes involved in another large-scale conflict. ${ }^{67}$ To its credit, VFW made substantial efforts to attract younger veterans and approximately 15\% of eligible Iraq and Afghanistan Veterans have joined. ${ }^{68}$ Still, this historically high market penetration among a smaller cohort of young veterans simply cannot counteract the demographic reality as much larger groups of older veterans pass away ${ }^{69}$ The existential threat these trends pose to VFW's continued political and policy influence cannot be overstated. In 2014, only 7\% of VFW membership was 41 or younger while $19 \%$ were 87 or older. ${ }^{70}$

${ }^{63}$ Rick Montgomery, “VFW Battles Declining Membership,” Kansas City Star, August 24, 2014, A1.

${ }^{64}$ Mark Hrywna, “New Veterans' Charities Race Past Broader Sector,” The NonProfit Times, December 1, 2013, 4.

${ }^{65}$ Paul Feely, "VFW Posts Looking to Grow Younger," The New Hampshire Union Leader, June 23, 2013, accessed April 29, 2014, http://search.proquest.com/docview/1370488463?accountid=28992.

${ }^{66}$ Tim Dyhouse, “Where Will VFW Be in Five Years?,” VFW Magazine, February 2013, 50-51, accessed April 29, 2014, http://search.proquest.com/docview/1412848879?accountid=28992.

67 Tim Dyhouse, “Where Will VFW Be in Five Years?”

${ }^{68}$ Alex Breitler, "Veterans Groups Seek to Boost Membership,” The Record (Stockton, CA), May 26, 2013, accessed April 29, 2014, http://search.proquest.com/docview/1355397299?accountid=28992.

${ }^{69}$ There are also questions about the retention rates and commitment of these younger members. Many were recruited through VFW's Military Initiative Program, established in 2000, which extended free, one year memberships to servicemembers of both the active and reserve components.

${ }^{70}$ Rick Montgomery, “VFW Battles Declining Membership.” 
Between the passage of the landmark GI Bill of Rights in 1944 and the late 1980s, VSOs gradually transitioned from a primary reliance on moral persuasion for legislative success to a strategy based on ever-increasing membership as a means of conveying clout to legislators. ${ }^{71}$ Size became the most important measure of VSO influence and as they became grassroots power players, the organizations repeatedly used their membership numbers to shape congressional support for policy preferences. ${ }^{72}$ Even though the VFW did not hit its peak membership level until 1992, prescient observers of the veterans' subgovernment noted as early as 1987 that looming demographic trends and societal changes would eventually diminish VSO power that relied too heavily on membership size and continued growth. ${ }^{73}$ Now, the VSOs find themselves in a situation where they desperately search for ways to stabilize their member rolls to preserve influence. In a recent column, the American Legion's national commander exhorted the rank-andfile by saying, "Without our membership numbers, our message would carry far less weight ... Personally recruit every eligible veteran you can. Our impact today and ability to serve in the future all depend on membership.”74

Consequences of Membership Trends on Traditional VSO Legislative Influence

These membership challenges have real consequences for VFW and similar organizations. By early 2013, VFW had already reduced its professional staff by about 40 and cut

${ }^{71}$ Paul C. Light, Forging Legislation, 21.

72 In his book documenting the legislative history of the Department of Veterans Affairs Act during the $100^{\text {th }}$ Congress (1987-1989), Paul Light provides several examples of how VSOs explicitly used their membership strength to pressure Congress. Light's reprinting of a March 15, 1988 letter from the VFW Executive Director to former Senator John Glenn (D-OH) is illustrative. Ibid., 100-101.

${ }^{73}$ Paul C. Light, Forging Legislation, 21-22. In a September 3, 2014 conversation with the author, Dr. Norman Ornstein shared his observation that VSOs do not have power built on moral authority the way they did in the past. July 2014, 8.

${ }^{74}$ Daniel M. Dellinger, “The Measure of American Legion Impact,” American Legion, 
its expenses in nearly every area. It may further implement an additional round of staff reductions in the near future. ${ }^{75}$ Ironically, these reductions come at the same time that VFW service officers are providing VA benefit claim assistance to a growing number of veterans. ${ }^{76}$ The organization recently increased its membership dues to wean itself from a historic dependence on solicitation revenue $^{77}$ and faces increased fundraising competition from newer veterans’ organizations and charities. ${ }^{78}$ The VFW's acquisition of new donors declined by 37\% between 2010 and 2013. This further impacted a once dependable source of revenue. ${ }^{79}$ With reduced revenues, declining numbers of professional staff, and a shrinking presence within local communities (and congressional districts), VSOs like the VFW and American Legion are no longer the nearly invincible advocacy organizations they were as recently as the 1990s.

Out of necessity, then, VSOs have joined issue coalitions with organizations whose membership demographics and member priorities differ from their own. ${ }^{80}$ Issue coalitions offer VSOs a number of advantages, but they principally offer a means of expanding increasingly scarce resources. ${ }^{81}$ Interest groups within an issue coalition are better able to leverage their combined lobbying efforts for legislative priorities and enter these arrangements expecting to

75 Tim Dyhouse, “Where Will the VFW be in Five Years?”

${ }^{76}$ Mark Hrywna, “New Veterans’ Charities Race Past Broader Sector.”

${ }^{77}$ Ibid.

${ }^{78}$ The increased crowding of new organizations within the veterans' fundraising sector means that established organizations must spend ever increasing amounts to sustain their donor list. For example, the VFW now spends approximately $\$ 40$ in solicitation costs for every $\$ 100$ it raises through direct mail or telephone solicitation. Rick Montgomery, "VFW Battles Declining Membership.”

${ }^{79}$ Mark Hrywna, “New Veterans’ Charities Race Past Broader Sector.”

${ }^{80}$ In a telephone conversation with the author on March 2, 2014, Dr. Lawrence Korb, Senior Fellow with the Center for American Progress, outlined the growing trend of VSOs aligning with issue coalitions whose members may have competing legislative priorities. Dr. Korb contends that the VSOs have entered these coalitions in an attempt to maintain their influence with Congress.

${ }^{81}$ See Jeffrey M. Berry and Clyde Wilcox, The Interest Group Society, $5^{\text {th }}$ ed. (New York: Pearson Longman, 2009), 157. 
devote some resources to achieving the goals of their partners. In recent years, VFW and the American Legion joined ad hoc issue coalitions with organizations such as the Military Officers Association of America (MOAA) and the Reserve Officers’ Association (ROA) among others. These organizations, while tangentially involved in veterans’ policy, have different membership demographics and policy priorities than the mainline VSOs. For example, VSO involvement in this coalition required their extensive participation in recent efforts to reverse congressionallydirected cuts to cost of living increases for working age military retirees. This issue did not have salience with the majority of VSO members as those organizations have proportionally few working age military retirees as members. Nonetheless, VSOs expended tremendous political capital assisting coalition members like MOAA and ROA to achieve a key legislative victory for them. These extraordinary lobbying efforts, which balanced policy risk with political risk, ultimately weakened the VSOs' ability to advance their own chief legislative priorities shortly thereafter (e.g. the Senate defeat of S. 1982). ${ }^{82}$

The Rise of New Veterans Advocacy Groups and Their Impact on the Policy Debate

Several new veteran advocacy groups have emerged in recent years, most notably IAVA, Concerned Veterans for America (CVA), and the Wounded Warrior Project (WWP). While increasingly influential in the political and media realms, these organizations do not broadly advocate for the interests of veterans from all eras, nor are they built on the democratic governance model rooted in grassroots civic engagement common among the traditional VSOs. Instead, they are managed in a more top-down manner by professional advocates with minimal opportunities for policy influence from the rank-and-file membership. ${ }^{83}$ Some fear that in an era

${ }^{82}$ Dr. Lawrence Korb, telephone conversation with the author, March 2, 2014; Leo Shane III, “Senate Blocks Huge Vets Benefits Bill,” Army Times, March 10, 2014, 24.

${ }^{83}$ Leo Shane III, “IAVA Attracts the Spotlight - and Detractors,” Stars and Stripes, September 5, 2012, accessed July 23, 2014, http://www.stripes.com/iava-attracts-the-spotlightand-detractors-1.188171. 
of finite fundraising opportunities and public attention, these narrowly focused but media savvy organizations will further siphon money, influence, and community from the already weakened traditional VSOs. ${ }^{84}$

The organizational model employed by IAVA, CVA, and WWP follows a four-decade trend among advocacy organizations of all types away from democratic governance and towards professional management with relatively detached membership..$^{85}$ This model has five general characteristics: 1) essentially “memberless” structures without local chapters; 2) a highly visible leadership cadre; 3) a narrower focus than the organizations they supplant; 4) less cross-cutting across social and economic class; and 5) a focus on direct appeals to deep pocket donors. ${ }^{86}$ IAVA claims almost 300,000 “members and supporters" ${ }^{87}$ but does not clarify how many of these individuals are veterans themselves. IAVA members do not pay membership dues nor is it clear how many actively participate in the organization beyond passively receiving information via email and social media. A small, professional staff comprised primarily of non-veterans ${ }^{88}$ develops and disseminates messaging to the membership but these interactions are among individuals

\footnotetext{
${ }^{84}$ Ryan Berg, “The Community Some Have Forgotten,” Iowa State Daily, November 2, 2010, accessed July 27, 2014, http://issuu.com/iowastatedaily/docs/11.02.10-daily; Rick Montgomery, "VFW Battles Declining Membership."

85 Theda Skocpol, "Unravelling From Above,” The American Prospect no. 25 (MarchApril 1996): 20-25, accessed February 6, 2014, http://xroads.virginia.edu/'HYPER/DETOC/assoc/25-cnt2.html.

${ }^{86}$ Morris P. Fiorina with Samuel J. Abrams, Disconnect: The Breakdown of Representation in American Politics (Norman, OK: University of Oklahoma Press, 2009), 132133.

${ }^{87}$ Adam Tiffen, “America’s Veterans Are Losing Their Collective Voice,” Task and Purpose (blog), June 10, 2014, accessed July 23, 2014, http://taskandpurpose.com/Americasveterans-losing-collective-voice.

${ }^{88}$ The anonymous reviews from current and former IAVA staff that appear on the employment site Glassdoor are illuminating. These employees report that IAVA's headquarters experiences constant personnel turnover and that most of the staff are nonveterans. "IAVA Reviews,” Glassdoor.com, accessed July 23, 2014, http://www.glassdoor.com/Reviews/IAVAReviews-E505674.htm.
} 
anonymous to one another and only build what collective action theorists categorize as "weak ties." ${ }^{89}$ Impersonal groups with anonymous memberships traditionally afford their members few opportunities for entrepreneurship or grass roots action ${ }^{90}$ as key decision making and strategy is clustered around a small, oligarchic leadership. ${ }^{91}$

Despite these organizational differences compared to traditional VSOs, IAVA quickly grew into an advocacy powerhouse and its founder, Paul Reickhoff, was highly visible during the 113th Congress and especially during the height of the scheduling scandal. Using a more aggressive style to get attention for its priorities, IAVA directly competes with the mainstream VSOs for earned media and public attention and has at times openly questioned the relevancy of their traditional face-to-face meetings. ${ }^{92}$ Its more confrontational approach makes many others within the VSO community uneasy ${ }^{93}$ and may ultimately push them towards similar tactics in an attempt to appear relevant. ${ }^{94}$

One of the preferred ways for new interest groups to overcome the barriers to formation and survival is the cultivation of wealthy patrons, institutional or individual benefactors who

${ }^{89}$ Bruce Bimber, Andrew J. Flanagin and Cynthia J. Stohl, Collective Action in Organizations: Interaction and Engagement in an Era of Technological Change (Cambridge: Cambridge University Press, 2012), 90.

${ }^{90}$ Ibid., 99.

91 Theda Skocpol, Diminished Democracy, 222-223.

${ }^{92}$ IAVA spokeswoman, Chrissy Stevens, boldly asserted that "Facebook is the VFW hall of the future.” John Ryan, “Traditional Vets Groups Turn to Social Media,” Army Times, November 19, 2010, accessed July 23, 2014, http://www.armytimes.com/article/20101119/NEWS/11190315/Traditional-vets-groups-turnsocial-media.

${ }^{93}$ Leo Shane III, “IAVA Attracts the Spotlight - and Detractors.”

94 Theda Skocpol notes that in a crowded universe of similar organizations, media pressures usually push organizations to "raise their voices" and pursue a strategy of "drama and controversy." The relentless professionalization of advocacy organizations makes them even more dependent on capturing a greater share of finite media coverage and philanthropy dollars. This is ultimately a zero sum game. Theda Skocpol, Diminished Democracy, 236. 
contribute substantial resources to the group. ${ }^{95}$ The successful new veterans' organizations have assiduously embraced a fundraising and revenue model focused heavily on corporate underwriting, in-kind donations, and philanthropy rather than traditional direct mail, small dollar donors, and membership revenue. Their results have been nothing short of impressive. By 2011, IAVA received almost \$20 million annually in the form of donated services, to include the office space for its New York City headquarters. ${ }^{96}$ The group’s 2012 annual report lists a constellation of corporate donors and wealthy patrons, some of whom appear to have an interest in the increased privatization of VHA services ${ }^{97} \mathrm{CVA}$, a strident critic of VA that focuses almost exclusively on political activism and advocacy for radical changes to VHA rather than the provision of direct services to veterans, recently received \$2 million through the extensive conservative political network established by Charles and David Koch. ${ }^{98}$

Of all the new organizations however, WWP is the fundraising leviathan and few charities of any type ever experience the incredible rate of growth it saw between 2009 and 2012 where revenue nearly doubled each year. ${ }^{99}$ WWP's growing political influence is noteworthy. In the 111th Congress, it was a vocal advocate for the Caregivers and Veterans Omnibus Health

${ }^{95}$ Anthony J. Nownes, Interest Groups in American Politics: Pressure and Power, 2d ed. (New York: Routledge, 2013), 49.

${ }^{96}$ Leo Shane III, "IAVA Attracts the Spotlight - and Detractors.”

${ }^{97}$ In 2012, IAVA reported receiving over $\$ 500,000$ from the TriWest Healthcare Alliance and between \$100,000 and \$249,000 from United Healthcare Military \& Veterans Services. In 2013, VA awarded TriWest a 5 year contract to manage the Patient-Centered Community Care Program for 8 of its 21 VISNs. Both TriWest and United potentially stand to benefit from any expansion of VHA's contract care initiatives. Leading at Home: IAVA 2012 Annual Report (New York: Iraq and Afghanistan Veterans of America, 2013), 20-21, accessed September 12, 2014, http://issuu.com/iava/docs/iava-2012_annual_report.

${ }^{98}$ Eric Alterman and Reed Richardson, "How the Media's VA 'Scandal' Coverage is Making the Same Old Mistakes,” The Nation, May 20, 2014, accessed May 29, 2014, http://www.thenation.com/blog/179937/how-medias-va-scandal-coverage-making-same-oldmistakes.

${ }^{99}$ Mark Hrywna, “New Veterans’ Charities Race Past Broader Sector,” 4. 
Services Act of 2010 (P.L. 111-163) ${ }^{100}$ which entitles severely injured veterans that served on or after September 11, 2001, whether or not they were injured in service or afterwards, with a generous family caregiver allowance. This advocacy campaign elicited some controversy within the larger VSO community because it represented the first time in recent memory that one category of veterans were conferred a benefit "to the exclusion of other, equally disabled veterans” under identical circumstances. ${ }^{101}$ For example, P.L. 111-163 authorizes family caregiver benefits to post-9/11 veterans with disabling Post-Traumatic Stress Disorder (PTSD) but excludes veterans from earlier conflicts that also have severe PTSD. In contrast, the traditional, post-World War II VSO model focused collective efforts towards securing benefits for veterans of all eras. WWP and IAVA's narrower policy and legislative focus have achieved some notable successes for narrow categories of veterans and this may be a harbinger of increasingly diffuse veterans’ advocacy at the same time that overall membership declines.

\section{Part 2}

The 113th Congress: The Accelerated Unravelling of the Veterans' Subgovernment Emerging Trends in the 113th Congress

A congressional champion of the Veterans Health Administration recently observed that “hyper-partisanship has infected the United States Congress and the broader public discourse.”102 This atmosphere within the 113th Congress and the congressional response to widespread scheduling improprieties at VA medical centers illustrate the trend of increased partisanship

${ }^{100}$ Caregivers and Veterans Omnibus Health Services Act of 2010, Public Law 163, 111th Cong., 2d sess. (May 5, 2010), accessed September 8, 2014, http://www.gpo.gov/fdsys/pkg/PLAW-111publ163/content-detail.html.

${ }^{101}$ Alex Graham, “Wounded Warrior Project - Saving Sargent (sic.) Ryan,” Veterans Today, February 16, 2014, accessed March 1, 2014, http://www.veteranstoday.com/2014/02/16/wwp-saving-sargent-ryan/.

102 Rep. John P. Sarbanes and Raymond O’Mara III, “Foreword: Elections in America,” Harvard Law \& Policy Review 8, no. 1 (Winter 2014): 1-20. 
within Congress on veterans’ policy, as well as the reduced influence of traditional veterans’ advocacy and service organizations. In the Senate, a comprehensive Veterans omnibus bill (S. 1982) introduced by Senator Bernard Sanders (I-VT), the Chairman of the Senate Committee on Veterans' Affairs, suffered a resounding procedural defeat in February 2014 when all but two Republican senators voted to block its advancement to a floor vote. ${ }^{103}$ Notably, this legislative package enjoyed near unanimous support from VSOs and advocacy groups. ${ }^{104}$ Despite the influence of S. 1982's supporters across the ideological spectrum, the political affiliation of senators superseded the traditional bipartisan support for large-scale veterans' legislative initiatives endorsed by major VSOs. ${ }^{105}$ The implementation of partisan obstructionism as a governing philosophy finally reached congressional veterans’ policy.

More broadly, throughout the 113th Congress, veterans' issues progressively became a proxy for larger partisan policy disagreements, such as U.S. policy towards Iran in the case of S. 1982 when Republican senators sought to offer nongermane amendments to an omnibus veterans’ bill. ${ }^{106}$ In the House, VA issues became part of a comprehensive political narrative for the 2014 midterm elections cycle as evidenced by House Speaker John Boehner's suggestion that recent problems related to VA health care were emblematic of Obama administration failures alongside U.S.-Mexico border issues, the stagnant economy, and concerns over Internal Revenue Service

${ }^{103}$ Leo Shane III, “Senate Blocks Huge Vets Benefits Bill.”

${ }^{104}$ Gregg Zaroya, "Senate Rejects Bill on Veterans Benefits: The Biggest Spending Bill in Decades Goes Down to Defeat in a Divided Senate,” USA Today, February 27, 2014, accessed March 1, 2014, http://www.usatoday.com/story/news/nation/2014/02/27/veterans-legislationbernie-sanders-senate/5859217.

105 Kimberley Railey, “Congress Lacks Veterans, Empathy, Critics Say,” Boston Globe, March 14, 2014.

106 In a September 3, 2014 telephone conversation with the author, Dr. Norman Ornstein explained that the procedural tactics employed in the Senate to block S. 1982 were unprecedented for a stand-alone veterans bill. 
activities towards certain political advocacy groups. ${ }^{107}$ Outlined below are the broad contours of these developments in the House and Senate.

The House: Increased Oversight and Aggressiveness

The HVAC, chaired by Rep. Jeff Miller (R-FL), continues to wage an increasingly acrimonious and visible oversight and investigative campaign into various VA programs. Miller assumed the HVAC chairmanship in 2011 after Republicans regained control of the House in the 2010 elections. Very early in his tenure, the Chairman replaced several key committee staff members with staff from his personal office. The committee’s tone towards VA changed markedly and Chairman Miller intentionally sought a more confrontational approach. ${ }^{108}$ The chairman’s attitude was evident among his staff responsible for VA oversight. In September 2011, the new HVAC Oversight \& Investigations (O\&I) Subcommittee Staff Director, Eric Hannel, confidently stated in a media interview that his top priority was "to hold the [VA] accountable, to combat its corporate culture and to ensure the voice of truth is heard.” 109

The Chairman and other members of the committee's majority became stridently critical of VA leaders and used its documented problems to amplify broader policy criticisms of the Obama administration. ${ }^{110}$ Miller is credited by some as being the first chairman to "upend the usual dynamic," the interdependent relationship between HVAC and VA. ${ }^{111}$ Through his

${ }^{107}$ Ed O’Keefe, “Problems at VA Still in Focus on Capitol Hill,” Washington Post, June 23, 2014, accessed June 23, 2014, http://www.washingtonpost.com/politics/problems-at-va-stillin-focus-on-capitol-hill/2014/06/23/4508757c-f62b-11e3-8aa9-dad2ec039789_story.html.

${ }^{108}$ David M. Drucker, “The Florida Republican who is Veterans Affairs' Worst Nightmare,” Washington Examiner, June 6, 2014, accessed June 14, 2014, http://washingtonexaminer.com/article/2549362.

${ }^{109}$ Kris Kitto, “Inside the Office of ... The House Veterans’ Affairs Committee Majority Staff,” The Hill, September 13, 2011, 23.

110 James Dao, “Criticism of Veterans Affairs Secretary Mounts Over Backlog in Claims,” New York Times, (May 19, 2013): A17.

${ }^{111}$ David M. Drucker, “The Florida Republican who is Veterans Affairs’ Worst 
committee hearings and public commentary, Chairman Miller did not hesitate to put VA officials on the defensive. Early in the 113th Congress, he publically called for the resignation of Allison A. Hickey, VA's current Under Secretary for Benefits ${ }^{112}$ and championed legislative efforts to allow the termination of career VA senior executives without regard to existing government-wide due process protections afforded to members of the Senior Executive Service (SES). ${ }^{113}$ In a Veterans Day 2013 editorial that appeared in The Washington Times, Chairman Miller launched a sharp rebuke to the Obama administration's oversight of VA and contrasted it with efforts taken to implement the Affordable Care Act. ${ }^{114}$

HVAC’s oversight agenda for the 113th Congress, released in January 2013, was a harbinger of increased destabilization within the veterans’ subgovernment. The committee’s ambitious agenda examined 25 issues specific to VHA as well as $27 \mathrm{VA}$-wide items related to access and transparency concerns. ${ }^{115}$ A transparency concern that would come to the fore in 2014 alleged that VA's Office of Congressional and Legislative Affairs (OCLA) provided "frequently inconsistent, incomplete, and untimely responses to requests for information from the committee” that impeded its performance of effective oversight. ${ }^{116}$ This focus by committee leadership helped cement a narrative of VA obstruction that the media picked up. The narrative took root within the

Nightmare.”

112 Ibid.

113 Joe Davidson, “Move Against Civil Service Protections Would Hurt VA,” Washington Post, February 21, 2014, A15.

${ }^{114}$ Rep. Jeff Miller, "Profiles in Problem Solving: Obamacare vs. the Department of Veterans Affairs,” Washington Times, November 11, 2013, 4, accessed September 11, 2014, https://veterans.house.gov/editorials/profiles-in-problem-solving-obamacare-vs-the-departmentof-veterans-affairs.

${ }^{115}$ House Committee on Veterans’ Affairs 113th Congress - Oversight Agenda, January 2013, accessed September 2, 2014, https://veterans.house.gov/sites/republicans.veterans.house.gov/files/documents/FINAL\%20113th \%20Congress\%20Oversight\%20Agenda\%2001152013.pdf.

${ }^{116}$ Ibid. 
committee and would dog VA throughout the 113th Congress and in a series of high profile and dramatic oversight hearings. By the time the patient scheduling scandal hit Congress with full force in May 2014, a bipartisan consensus already existed that VA’s OCLA, an entity VHA had minimal influence over, routinely withheld information requested by Congress. This perception put VHA in an incredibly disadvantageous position and impeded its ability to influence congressional and even some VSO stakeholders at a critical time. ${ }^{117}$

HVAC and its chairman further accelerated the committee’s aggressive oversight of VHA that punctuated, but did not define, its experience with the 112th Congress. Investigations launched in the 112th and 113th Congresses that culminated in contentious, high profile hearings explored VA’s internal response to a Legionnaires’ disease outbreak at its VA Pittsburgh Healthcare System, allegations of preventable patient deaths, and consult delays at a number of VHA facilities. These efforts consumed much of the committee's focus through 2013 and resulted in a stream of negative coverage for VHA that marked a partisan sea change. While HVAC historically conducted oversight of VA programs and policies under both parties, it did so episodically as the need arose rather than in a coordinated manner designed to impugn the ethics and motives of VHA senior leaders and generate sustained media attention. During the course of their wide-ranging investigations in the 113th Congress, HVAC Members and staff lodged a series of accusations against VA leadership that took on an unusually confrontational tone and seemed designed to generate maximum media attention. VA later identified some of the committee’s more incendiary accusations about quality lapses at VHA facilities as factually

${ }^{117}$ VSOs shared Congress' frustrations with VA’s growing lack of transparency in responding to congressional inquiries and FOIA requests. Rick Weidman, the Legislative Director for the Vietnam Veterans of America, said that "the past five years [2009-2014] have been the "least transparent the VA has ever been."” Leigh Ann Caldwell, "Congress Had Chances Over the Years, But Action on VA Not Enough,” CNN Politics (blog), June 23, 2014, accessed August 31, 2014, http://www.cnn.com/2014/06/23/politics/congress-va-scandal-role/. 
inaccurate or physiologically implausible. ${ }^{118}$ However, several committee accusations

investigated by VHA substantiated unfortunate events of negligence, misfeasance, and poor leadership. ${ }^{119}$ These adverse findings were then used by the committee's majority to draw continuous attention to the existence of VA employee performance bonuses even in situations where they were not an issue. ${ }^{120}$ The continued drumbeat of HVAC oversight activities, both substantiated and unsubstantiated, coalesced into a national media narrative of inadequate care at many VHA facilities and an unaccountable leadership bureaucracy. A November 2013 media analysis performed for VA by an outside contractor articulated the cumulative impact of this coverage on VHA. ${ }^{121}$ The analysis specifically noted that Chairman Miller's steady criticism on quality of care and malpractice issues contributed to negative narratives of inadequate care and fiscal irresponsibility. ${ }^{122}$

${ }^{118}$ An illustrative example of these incendiary accusations is a request that VHA received on September 16, 2013 from the staff director of HVAC's Oversight \& Investigations Subcommittee (via OCLA). The inquiry alleged that a "freezer burned" liver was transplanted into a veteran at the VA Pittsburgh Healthcare System and that VA needed to "come clean" about this procedure. Experts in organ transplantation quickly confirmed that the accusations were implausible given the way harvested organs for transplant are processed and stored. VHA offered the committee an information briefing on several occasions to clarify this matter, but it was never scheduled.

${ }^{119}$ Charles S. Clark, “Controversial VA Procurement Officer Should Be Fired, Lawmaker Says,” Government Executive, October 2, 2014, accessed October 2, 2014, http://www.govexec.com/contracting/2014/10/controversial-va-procurement-officer-should-befired-lawmaker-says/95702/?oref=river.

${ }^{120}$ Daniel Malloy, "VA Medical Center: Gingrey Calls for Firings at Atlanta VA: Audits Blame Facility for 3 Deaths of Patients Under Its Care,” Atlanta Journal Constitution, May 24, 2013, accessed May 1, 2014, http://search.proquest.com/docview/1354601040?accountid=28992.

${ }^{121}$ VA retained Barbaricum, a contractor that specializes in communications analysis, to evaluate media trends impacting its programs. Barbaricum was quite prescient in its analysis by detecting the disproportionate influence of HVAC Chairman Miller in the media and HVAC's role in amplifying an emerging narrative from the committee's oversight efforts. See Department of Veterans Affairs, VA Weekly Media Analysis Brief - 7-13 November 2013, Benjamin Krause, "VA Pays Millions for Spin-and-Stonewall Machine,” Disabled Veterans (blog), July 3, 2013, accessed July 6, 2013, http://www.disabledveterans.org/2014/07/03/va-pays-millions-spinstonewall-machine/.

122 Ibid. 
The evolution of HVAC's combative tone in the 112th and 113th Congresses fits within the growing desire among congressional leadership to make almost any issue a partisan one, even in policy areas where bipartisan comity persisted until quite recently. ${ }^{123}$ These trends reach far beyond HVAC and are also visible in the current House Science Committee, another traditionally collegial and low prestige committee, which began pursuing a more aggressive and party driven agenda in the 113th Congress against the Environmental Protection Agency, which partially falls under its jurisdiction. ${ }^{124}$

Evidence suggests that at least some of HVAC's adversarial posture against VA in the 113th Congress was actively encouraged by House leadership to develop a broader narrative of government mismanagement and inefficiency against the Obama administration. First, House Speaker John Boehner prominently lent his voice to one of Chairman Miller's most provocative and divisive policy proposals prior to the emergence of the patient scheduling scandal, the campaign to eliminate most due process safeguards for VA senior executives. ${ }^{125}$ Second, in an era of austerity on Capitol Hill, House leaders provided HVAC with a substantial funding increase for $2014^{126}$ that allowed the planned hiring of five committee investigators - more than doubling

${ }^{123}$ Dr. Norman Ornstein, telephone conversation with the author, September 3, 2014.

${ }^{124}$ Brad Johnson, “How One GOP-Controlled Committee Is Waging A War on Science,” Huffington Post, June 24, 2014, accessed June 24, 2014, http://www.huffingtonpost.com/2014/06/24/house-science-committee_n_5525609.html.

${ }^{125}$ Chairman Miller's early efforts to eliminate many due process safeguards for VA senior executives were considered divisive and partisan. Although a modified version of these proposals became law under P.L. 113-146, their eventual acceptance by Democrats stemmed from political pressures prompted by the patient scheduling scandal. Joe Davidson, "Move Against Civil Service Protections Would Hurt VA.”; Eric Katz, "Boehner: Make It Easier to Fire VA Execs,” Government Executive, April 3, 2014, accessed April 3, 2014, http://www.govexec.com/pay-benefits/2014/04/boehner-make-it-easier-fire-va-execs/81877/.

${ }^{126}$ HVAC spent approximately \$2.5 million in 2013 and received a \$3 million budget for 2014. Paul Singer, “House Benghazi Panel May Cost \$3 Million This Year,” USA Today, July 7, 2014, accessed July 8, 2014, http://www.usatoday.com/story/news/politics/2014/07/07/benghazicommittee-33-million-republicans/12301935/. 
its normal investigative staff. ${ }^{127}$ As the scheduling scandal grew in importance, Speaker Boehner further promised HVAC with additional staff and funding as needed to sustain and expand investigative efforts of high public interest. ${ }^{128}$ Third, as the normally low-visibility HVAC’s narrative spread in Congress and the media, leadership employed several means to amplify further its partisan utility in using the issue. The most prominent example of this was the selection of Rep. Jackie Walorski (R-IN) and Chairman Miller himself to deliver weekly Republican addressees where they used their platforms to advance several controversial policy proposals such as continued privatization of VA health care and the elimination of many employment protections for VA executives. ${ }^{129}$

In the current 113th Congress, Chairman Miller cultivated a constant and influential media presence as a critic of VA. This was observed in a VA analysis of media between September and November 2013 that stated that he provided the highest volume and most consistent commentary on VA of any political figure - virtually all of it negative. ${ }^{130}$ The chairman's consolidation of influence within the veterans' policy agenda was in some ways reminiscent of the earlier "iron triangle” era of powerful HVAC leaders, but differed starkly in its hostility to VA rather than in its deference. ${ }^{131}$

${ }^{127}$ Ed O’Keefe, "Problems at VA Still in Focus on Capitol Hill.”

${ }^{128}$ Ibid.

${ }^{129}$ Rep. Jackie Walorski (R-IN), Weekly Republican Address, March 29, 2014, accessed September 10, 2014, http://www.c-span.org/video/?318598-2/weekly-republican-address; Rep. Jeff Miller (R-FL), Weekly Republican Address, June 7, 2014, accessed September 7, 2014, http://www.c-span.org/search/?searchtype=All\&query=Jeff+Miller+Weekly.

${ }^{130}$ Department of Veterans Affairs, VA Media Targeted Report 15 - 23 September - 1 November 2013, Benjamin Krause, "VA Pays Millions for Spin-and-Stonewall Machine."

131 This statement deserves further context. Chairman Miller is not the first HVAC Chairman to exhibit a general hostility towards VA leadership, rather he is the first to combine this posture with an effective media presence aligned with the achievement of clear, political goals beyond the narrow confines of expanded veterans' benefits. Miller's Democratic predecessor, Rep. Bob Filner (D-CA), was incredibly hostile towards many individuals within VA, but generally seen as more uncivil and unfocused. For an illustrative example of Chairman Filner's histrionics towards VA witnesses, see Hearing before the House Committee on Veterans' 
Chairman Miller may have built up this unique influence in the 113th Congress because there was unusually little interest to serve on the 25-member HVAC, a committee notorious for having difficulty attracting and keeping members. For example, the Democrats were initially unable to fill their 11 allocated slots and had to ask Rep. Tim Walz (D-MN) to take on a third panel assignment - an unusual arrangement. ${ }^{132}$ Among the 11 HVAC Democrats in 2014, only four served in Congress before 2013. The Democratic ranking member on the committee, Rep. Michael Michaud (D-ME), spent most of the 113th Congress as a gubernatorial candidate in Maine; which necessarily limited his time and attention available for VA issues. On the Republican side, five Members on the panel were freshman and the Chairman himself was the only one with more than four terms in Congress. In recent Congresses, HVAC's paucity of senior members chronically deprived it of access to congressional leadership, media outlets, or the other levers of power within Washington because new members are generally less adept at these things. ${ }^{133}$ While the HVAC membership remains quite junior in the current environment, Chairman Miller built a formidable staff and media operation. Their ability to fill the vacuum and drive the narrative on VA in both houses of Congress is a testament to their efforts.

The Senate: Partisan Showdown over S. 1982

The Democratic-controlled Senate was not immune to the increasingly partisan approach to veterans' issues in the 113th Congress. The most illustrative example of this trend was the February 2014 defeat of S. 1982, the Comprehensive Veterans Health and Benefits and Military Retirement Pay Restoration Act of 2014, sponsored by Senator Bernard Sanders (I-VT), the

Affairs, Health Effects of the Vietnam War - The Aftermath, $111^{\text {th }}$ Cong., 2d sess., May 5, 2010, accessed December 2, 2014, http://archives.veterans.house.gov/hearings/hearing.aspx?NewsID=2237.

${ }^{132}$ Ryan Grim, “Here’s the Simple Reason Congress Hasn’t Fixed The VA.” 133 Ibid. 
SVAC Chairman. Sanders’ signature bill was the largest piece of proposed veterans’ legislation to emerge from committee in several decades and would have widely expanded the array of health care, education, and other benefits offered by VA. ${ }^{134}$ By design, it incorporated policy priorities from all major VSOs ${ }^{135}$ to ensure maximum support from the veterans’ community. ${ }^{136}$ Some Senate Republicans offered S. 1982’s estimated \$21 billion price tag as a post hoc justification for their opposition following the Majority Leader's decision to disallow amendments ${ }^{137}$ even though the final bill contained 26 provisions developed by Republican committee members in an attempt to secure bipartisan support and eventual passage. ${ }^{138}$

A cloture vote to end debate and allow the bill to move to a Senate floor vote garnered only 56 of the 60 votes needed. The vote was highly partisan, with only two Senate Republicans crossing party lines to support it, an almost unprecedented development for omnibus legislation concerning veterans’ issues. ${ }^{139}$ Senators voting against cloture attributed its defeat to Senate Majority Leader Harry Reid’s (D-NV) refusal to allow votes on Republican amendments that

${ }^{134}$ Gregg Zaroya, “Senate Rejects Bill on Veterans Benefits.”

135 The "wish list” nature of S. 1982 and Senator Sanders' “all or nothing” legislative strategy" may have contributed to its vulnerability in a polarized Senate. While individual VSOs were very committed to their signature issues contained in the bill, almost no one was strongly committed to the entire bill because of its vast scope.

${ }^{136}$ Senator Bernard Sanders (I-VT), interview by Greta Wodele Brawner, C-SPAN Newsmakers, May 22, 2014, accessed August 7, 2014, http://www.c-span.org/video/?3195221/newsmakers-sen-bernie-sanders-ivt.

${ }^{137}$ Zoe Carpenter, "Senate Republicans Turn Their Backs on Veterans,” The Nation, February 27, 2014, accessed March 1, 2014, http://www.thenation.com/blog/178574/senaterepublicans-turn-their-backs-veterans.

${ }^{138}$ Charles P. Pierce, “Senate Republicans Kill a Bill to Expand Veterans’ Benefits,” Esquire Politics Blog, February 27, 2014, accessed March 1, 2014, http://www.esquire.com/blogs/politics/senate-blocks-bill-expanding-veterans-benefits-022714.

${ }^{139}$ In a September 3, 2014 telephone conversation with the author, congressional scholar Norman Ornstein described the filibuster of an omnibus veterans' bill like S.1982 as “unprecedented.” See Alan Fram, “Democrats’ Bill Axed,” Kansas City Star, February 28, 2014, A2. 
would have trimmed the bill's size and added penalties against Iran for its nuclear program. ${ }^{140}$ The imposition of new penalties on Iran were intended to serve as a "poison pill” for S. 1982's ultimate passage by dividing Democrats and politically embarrassing the Obama administration which opposed such efforts. ${ }^{141}$

The Senate vote on S. 1982 was remarkable to observers of the veterans' subgovernment for two reasons: 1) it revealed the willingness of the Senate minority to inject divisive issues of great partisan salience (e.g. Iranian penalties) into veteran legislation in an attempt to derail its passage; and 2) 41 senators openly voted to stop a bill that enjoyed almost unanimous support among VSOs, calculating that there would be no political consequences for doing so. ${ }^{142}$ These developments clearly illustrate the ongoing destabilization of the subgovernment by further subverting the bipartisan reputation of veterans' issues and demonstrating the very limits of VSO influence in the current political environment. ${ }^{143}$

As evidenced by the process used to craft S. 1982, SVAC Chairman Sanders spent much of the 113th Congress reaching out in a bipartisan manner to all fourteen senators on his committee. The institutional nature of the Senate demands this approach and restricts a

${ }^{140}$ Alan Fram, “Democrats’ Bill Axed.”

${ }^{141}$ Sean Theriault, a Professor of Political Science at the University of Texas, terms this process as "death by amendment" and he contends the Senate minority employed it with increasing effectiveness since 2007. The explicit strategy of filibustering would appear unseemly if too frequently used, so the use of amendments is considered a less impolitic strategy. Because each amendment requires debate, and if the Senate decides, a roll-call vote, it has the same effect as a filibuster. A shrewdly written amendment can divide the majority party, and force electorally vulnerable senators to cast a vote. Sean Theriault, The Gingrich Senators, 94.

${ }^{142}$ Alan Fram, “Senate Blocks Dems’ Bill Boosting Vets’ Benefits,” The Associated Press Big Story, February 27, 2014, accessed June 22, 2014, http://bigstory.ap.org/article/senateheads-toward-showdown-vote-veterans-bill.

${ }^{143}$ Dr. Norman Ornstein advances a theory of waning VSO influence in the modern Congressional environment. Politicians can now advocate for "veterans" generally and avoid any negative consequence, but they do not have to deal directly with VSOs as they once did. As the perception grows that there are no adverse political consequences for opposing VSO policy preferences, their relative influence in the legislative process dissipates. Dr. Norman Ornstein, telephone conversation with the author, September 3, 2014. 
chairman's ability to drive the oversight agenda or only use coercive tools to advance his preferred policy positions. Nonetheless, as the patient scheduling scandal grew in visibility, some Republican senators, such as Tom Coburn (R-OK), openly criticized Sanders’ stewardship of SVAC and alleged the committee was too idle and conducted insufficient oversight hearings in comparison with HVAC. ${ }^{144}$ These critiques failed to account for inherent structural constraints within the Senate itself. First, the SVAC is a small, minor committee without subcommittees with among the smallest budgets in the Senate. Second, its members serve on 3-to-5 other committees in the Senate and have less time than the House to devote to VA issues. ${ }^{145}$ Finally, a Senate committee chairman's power to steer oversight investigations is not unilateral because, unlike the House, it generally needs minority party support; furthermore, it is difficult to suppress an investigation that minority committee members demand because individual senators retain great procedural powers. ${ }^{146}$ Thus, opening a formal oversight investigation in a partisan Senate environment can have both positive and negative political consequences for the majority. Given its traditionally limited resources and time, the SVAC typically conducts a much more restrained form of oversight than the HVAC known as "incidental oversight” which is conducted as part of its regular committee hearings. ${ }^{147}$ While SVAC may schedule infrequent explicit oversight hearings, oversight items comprised a large part of its regular hearings during recent years. ${ }^{148}$

\footnotetext{
${ }^{144}$ Senator Tom Coburn (R-OK), Oversight Report: Friendly Fire - Death, Delay \& Dismay at the VA.

${ }^{145}$ In recent years, senators averaged 3.9 committee assignments and 8.1 subcommittee assignments. These demands in conjunction with fundraising obligations force them to operate under severe time pressures. Barbara Sinclair, Unorthodox Lawmaking: New Legislative Processes in the U.S. Congress, $4^{\text {th }}$ ed., 53.

${ }^{146}$ David C.W. Parker, and Matthew Dull, "Divided We Quarrel: The Politics of Congressional Investigations, 1947-2004,” Legislative Studies Quarterly 34, no. 3 (August 2009): 319-345, 328.

${ }^{147}$ Matthew D. McCubbins and Thomas Schwartz, "Congressional Oversight Overlooked: Police Patrols Versus Fire Alarms,” American Journal of Political Science 28, no. 1 (February 1984): 165-179, 166.

${ }^{148}$ Examples of SVAC “indirect oversight” efforts that the author personally participated
} 
VHA’s 2014 Scheduling Scandal - Competing Priorities and Role Conflict

On April 23, 2014, the cable news network CNN reported that several dozen veterans enrolled at the Phoenix VA Health Care System (PVAHCS) may have died as a result of excessively long wait times for certain clinic appointments. ${ }^{149}$ The story further alleged that PVAHCS staff placed thousands of patients on unauthorized waiting lists in an attempt by facility leadership to conceal the fact that many patients were waiting longer than the fourteen-day access to care stipulated in VA directives. While this was not the first investigative piece that CNN recently ran that alleged improprieties at VA medical centers, it was the first to gain widespread traction among the larger media and political universe. ${ }^{150}$ The initial reporting helped catalyze a chain of events that are still unfolding and illustrate the changed dynamics within the veterans' policy subgovernment.

The Phoenix scheduling crisis quickly spurred a flood of critical reporting by a variety of media outlets. Much of this early reporting was superficial and sensationalized as few journalists regularly cover VA issues. ${ }^{151}$ This intense coverage quickly captured national attention and drew

in include Hearing before the Senate Committee on Veterans' Affairs, VA Mental Health Care: Closing the Gaps, $112^{\text {th }}$ Cong., $1^{\text {st }}$ sess., July 14, 2011; and Hearing before the Senate Committee on Veterans' Affairs, VA Mental Health Care: Addressing Wait Times and Access to Care, $112^{\text {th }}$ Cong., $1^{\text {st }}$ sess., November 30, 2011.

${ }^{149}$ Scott Bronstein and Drew Griffin, “A Fatal Wait: Veterans Languish and Die on VA Hospital’s Secret List,” CNN Health April 23, 2014, accessed July 27, 2014, http://www.cnn.com/2014/04/23/health/veterans-dying-health-care-delays/.

${ }^{150}$ CNN Investigations aired at least two major reports since December 2012 that documented problems at VA medical centers, specifically, the 2012 Legionnaires' Disease outbreak at the VA Pittsburgh Healthcare System and patient deaths resulting from lengthy consult days at the William Jennings Bryan Dorn VAMC in Columbia, South Carolina. See Nelli Black, and Drew Griffin, "VA Under Scrutiny After Legionnaires' Cases in Pittsburgh,” CNN Health, December 14, 2012, accessed July 27, 2014, http://www.cnn.com/2012/12/13/health/legionnaires-hospital-water/index.html?iref=allsearch; and Scott Bronstein, Nelli Black, and Drew Griffin, "Hospital Delays Are Killing America's War Veterans,” CNN Health, November 20, 2013, accessed July 27, 2014, http://www.cnn.com/2013/11/19/health/veterans-dying-health-care-delays/.

${ }^{151}$ In May 2014, Brandon Friedman, a former special advisor in VA’s Office of Public and Intergovernmental Affairs, commented on the relatively poor quality of initial reporting on 
additional media and congressional scrutiny of VHA. By early May, VA acknowledged that an informal review revealed that the issues documented at Phoenix were not isolated but part of a systemic pattern of improper patient scheduling at dozens of VA facilities throughout the country.

The release of an interim VA Office of Inspector General (OIG) report on May 28, 2014 substantiated the allegations of patient wait time manipulations at PVAHCS, further exacerbated emotions within Congress. That day, HVAC Chairman Miller called for the immediate resignation of VA Secretary Shinseki and joined the growing ranks of Members to do so. ${ }^{152}$ Vulnerable Senate Democrats seeking reelection in 2014 most acutely felt the rapidly growing political implications of the VA scheduling scandal. ${ }^{153}$ Many had refrained from calling for Shinseki's ouster pending the outcome of formal investigations, but as political attacks on this front escalated, many broke ranks and called for him to step down. Facing a building crescendo of demands for his resignation, Secretary Shinseki announced his departure from VA on May 30, 2014.

\section{House Hearings}

The revelation of scheduling improprieties at the Phoenix VAMC began as an HVAC investigation when Chairman Miller wrote VA on April 9, 2014 and requested the preservation of all records related to delayed medical appointments. ${ }^{154}$ As the incident gained attention following

the VA scheduling issue. Brandon Friedman, Twitter post, May 19, 2014 (6:23 p.m.), accessed August 7, 2014, https://twitter.com/BFriedmanDC.

152 Josh Hicks, “Inspector General’s Report Confirms Allegations at Phoenix VA Hospital,” Washington Post, May 28, 2014, accessed May 29, 2014, http://www.washingtonpost.com/blogs/federal-eye/wp/2014/05/28/ig-report-confirms-allegationsat-phoenix-va-hospital/.

153 Jacqueline Klimas, "VA Scandal Creeps into Congressional Races, but Little Impact Expected,” Washington Times, September 3, 2014, accessed September 5, 2014, http://www.washingtontimes.com/news/2014/sep/3/va-scandal-creeps-into-congressional-racesbut-lit/?page=all.

${ }^{154}$ Ken Olsen, “VA’s Series of Unfortunate Events,” American Legion, July 2014, 22. 
subsequent extensive CNN coverage, the HVAC maximized opportunities to increase national exposure for its oversight activities. A series of high visibility oversight hearings generated the most exposure for HVAC’s efforts. Since the veterans' committees receive minimal attention within the larger congressional community, Chairman Miller took the unorthodox step of starting HVAC hearings after 7 p.m. and letting them run late into the night. The timing for these hearings ensured maximum committee member attendance and focus while drawing broad media attention and C-SPAN coverage - visibility that HVAC normally does not enjoy during its business hour activities. ${ }^{155}$ These hearings amplified the confrontational relationship between the committee and VA while showcasing the deep, bipartisan mistrust the panel had developed towards VA. The steady pace of high profile committee activity persisted in keeping VHA health care in the public’s eye.

HVAC conducted its series of marathon oversight hearings in a manner entirely consistent with partisan trends observed in the House during recent periods of divided government, but traditionally outside the bipartisan policy realm of veterans’ affairs. ${ }^{156}$ These high profile investigations allow for position taking and reputation building by committee and party leadership. By pointing to alleged government mismanagement and malfeasance, they influence their target audiences and erode public support for the existing policies and political leadership under scrutiny. ${ }^{157}$ The primary target audience of committee oversight hearings is the legislature itself and they alert the larger Congress to issues that received little attention within

${ }^{155}$ Leo Shane III, “Evening Meetings Boost Attendance at House VA Panel,” Army Times, July 8, 2014, accessed July 25, 2013, http://www.armytimes.com/article/20140708/NEWS05/307080078/Evening-meetings-boostattendance-House-VA-panel.

${ }^{156}$ David C.W. Parker, and Matthew Dull, "Divided We Quarrel: The Politics of Congressional Investigations, 1947-2004,” 325.

${ }^{157}$ David C.W. Parker, and Matthew Dull, "Divided We Quarrel: The Politics of Congressional Investigations, 1947-2004,” 325. 
the legislature as a whole. ${ }^{158}$ When VA, an agency with a low profile in Congress, became the target of high visibility oversight activities, the investigating committee’s narrative, forged in an inherently political context, took root and framed the larger congressional debate in both chambers. HVAC’s framing was especially influential because its Senate counterpart lacked a dedicated press office and VA launched an ineffectual response to the committee's initial allegations. Members of Chairman Miller's staff were the only ones in Congress running a coordinated messaging effort as fallout from the scheduling scandal VA mounted. By default, HVAC became a source of information for legislators and their staff seeking answers on an issue of great constituent concern.

Conflict within the Veterans Community

As the VA scheduling crisis grew in significance, the mainstream VSOs did not demonstrate the characteristic unity shown during previous VA scandals. The American Legion, widely regarded as the most important of the VSOs, ${ }^{159}$ broke ranks with the larger VSO community less than two weeks after CNN first reported wait time irregularities in Phoenix. On May 5, 2014 Daniel Dellinger, the Legion's National Commander, publicly called for the resignations of VA Secretary Eric Shinseki, Under Secretary for Health Robert Petzel, and Under Secretary for Benefits Allison Hickey. ${ }^{160}$ This action surprised many and had wide reverberations throughout the veterans' policy subgovernment. The American Legion had not called for the

${ }^{158}$ Brian D. Feinstein, "Supplement to: Congressional Control of Administrative Agencies,” Social Science Research Network Working Paper Series, July 31, 2013, 4-5, accessed August 17, 2014, http://ssrn.com/abstract=2073774.

${ }^{159}$ Nicole Schiller, “Examining Veterans’ Interest Groups: Understanding Success Through Interest Group Ratings,” Res Publica - Journal of Undergraduate Research 13, no. 1 (2008):64-76, 66.

${ }^{160}$ Ken Olsen, "VA’s Series of Unfortunate Events." 
resignation of a cabinet level official since 1941 and this action greatly altered the political discourse within Congress and how subsequent events would unfold for VHA. ${ }^{161}$

Despite the Legion's announcement, almost all VSOs initially stood by the embattled Secretary, focusing their efforts instead on demanding an improvement in patient access and accountability for those who reported misleading access metrics. Tellingly, this measured position frustrated those congressional leaders maximizing the political impact of the scandal by campaigning for Shinseki's removal and using the crisis to advance institutional changes for VHA that were long considered radical. In an attempt to exploit deepening divisions within the VSO community, Senator Richard Burr (R-NC), the SVAC ranking member, penned an open letter to national VSO leadership. In the letter he explicitly praised the American Legion and alleged that other VSOs were "more interested in defending the status quo within VA" and that their professional staff ignored the needs of rank-and-file membership. ${ }^{162}$ Senator Burr's letter drew an uncharacteristically firm response from VSO leadership who promised a more confrontational relationship with Congress going forward. ${ }^{163}$ Senator Burr’s open letter had a deep symbolic effect as it appeared to upend the very concept of the "iron triangle” that governed the veterans' subgovernment for so many years. Now, instead of using their positional power to pressure Congress to support VA programs, the VSOs themselves were pressured by increasingly powerful congressional actors to become more confrontational towards VA.

${ }^{161}$ Josh Hicks, “American Legion Calls for the Resignation of VA Secretary Eric Shinseki,” Washington Post, May 5, 2014, accessed July 27, 2014, http:/www.washingtonpost.com/blogs/federal-eye/wp/2014/05/05/american-legion-calls-forresignation-of-va-secretary-eric-shinseki/.

${ }^{162}$ Steven Dennis, "VFW Torches Burr in Spat Over VA Scandal, Shinseki,” Roll Call, May 24, 2014, accessed July 27, 2014, http://blogs.rollcall.com/wgdb/vfw-torches-burr-in-spatover-va-leadership/?dcz=.

163 Steven Dennis, “VFW Torches Burr in Spat Over VA Scandal, Shinseki.” 
Importantly, by expressing no confidence in three senior VA officials and publicly breaking ranks with other VSOs, the Legion provided the political cover for congressional leaders to call for Secretary Shinseki’s resignation. Relying on the Legion's pronouncement, critics of VA and the administration could now simply appear to echo the preferences of the nation's largest veterans organization and thereby inoculate themselves against plausible charges of partisan politics. ${ }^{164}$ Rep. Jackie Walorski (R-IN), an HVAC member who called for Shinseki’s resignation following the Legion’s announcement, explained that “it was absolutely pivotal because of their credibility, it for sure opened the door. I was just responding to that call." 165 It appears that a number of Members followed a similar political calculus as the calls in Congress for Secretary Shinseki’s resignation grew. At the 2014 American Legion national meeting, Senator Richard Burr (R-NC) used a keynote address to thank the Legion and he directly attributed their support to the ultimate resignation of Secretary Shinseki. ${ }^{166}$ This would not be the last time in 2014 that the Legion broke with the larger VSO community by advocating policy positions favored by congressional Republicans critical of VA.

Veterans Reform Legislation - The Path to Public Law 113-146

On August 7, 2014, President Barack Obama signed the Veterans Access, Choice, and Accountability Act of 2014 (P.L. 113-146) into law at a ceremony attended by Republican and Democratic Members of Congress. Congress passed the act in direct response to issues uncovered

164 Tony Cook, “American Legion Played a Key Role in VA Resignation,” Indianapolis Star, May 30, 2014, accessed July 27, 2014, http://www.indystar.com/story/news/politics/2014/05/30/va-secretary-shinseki-resigns/9766737/.

165 Ibid.

${ }^{166}$ Senator Richard Burr (R-NC), Opening Remarks to the American Legion 96 ${ }^{\text {th }}$ National Convention, Charlotte, NC, August 26, 2014, accessed August 27, 2014, http://www.legion.org/legiontv?pid=latest\&v=2ltzDYWyrqg. 
during the patient scheduling scandal. In a raft of superficial media coverage, observers hailed the bill as "a rare bipartisan agreement." 167

A deeper exploration of the legislative history, however, shows that a partisan political interest intensely motivated incumbent members of the House and Senate to pass it as quickly as possible in order to mitigate potential damage from an issue of high public interest. ${ }^{168}$ Furthermore, despite the broad consensus to move reform legislation quickly, a number of high profile, partisan road blocks slowed the Republican House and Democratic Senate's eventual compromise and agreement. Congressional leaders initially predicted the mid-June passage of the legislation that President Obama signed in August. In the interim, Congress missed at least two subsequent deadlines set by committee leadership. ${ }^{169}$

In retrospect, it appears the Democrats collectively stood the most to lose politically from a failure to respond quickly to the VHA scheduling scandal. Republicans quickly deployed partisan arguments to tie the issue to other failures within the Federal government. The scandal was further injected into the races of vulnerable Democratic Senate incumbents to associate them with the Obama administration. ${ }^{170}$ Still, Republicans were also compelled to act quickly. After

${ }^{167}$ Michael C. Bender, “Congress Sends Obama Bipartisan Deal for Veterans’ Health,” Bloomberg News, July 31, 2014, accessed September 13, 2014, http://www.bloomberg.com/news/2014-08-01/congress-sends-obama-bipartisan-deal-forveterans-health.html.

${ }^{168}$ Damian Paletta of The Wall Street Journal elaborated on this dynamic during a CSPAN interview. The political potency of the VA scheduling crisis was immediate to both parties and they mobilized quickly to find a solution. Paletta described incumbents of both parties as "politically scared to death of the consequences" of not being seen as ameliorating the situation at VA. Damian Paletta, Wall Street Journal, Economic Policy Reporter, interview by Pedro Echevarria, C-SPAN Washington Journal, June 7, 2014, accessed September 7, 2014, http://www.c-span.org/video/?319633-6/washington-journal-veterans-affairs-health-services.

${ }^{169}$ Leo Shane III, "VA Reform Bills Stalled by Partisan Bickering,” Military Times, July 24, 2013, accessed July 25, 2014, http://www.militarytimes.com/article/20140724/BENEFITS04/307240080/VA-reform-billsstalled-by-partisan-bickering.

${ }^{170}$ Kyle Trygstad, “Democrats Work to Mitigate VA Scandal as Political Issue,” Roll Call, July 1, 2014, accessed July 7, 2014, http://atr.rollcall.com/veterans-affairs-scandal- 
deploying the rhetoric of scandal and politicizing a high visibility issue, they had to take meaningful steps to solve the problem. ${ }^{171}$ This dynamic created a will among both parties to "do something” quickly, preferably before to the start of August recess.

A bipartisan sense of urgency led to the development of legislation categorized as "crisis policy" ${ }^{172}$ which would not have satisfied the policy preferences of most stakeholders in a more deliberative environment. ${ }^{173}$ In June, the House and Senate hastily passed versions of VA reform legislation ${ }^{174}$ and the leadership of both chambers formed a rare conference committee to reach a compromise between the two competing proposals. This was the first conference committee assembled to reconcile legislation between HVAC and SVAC since 1999 and underscored the bipartisan sense of urgency. ${ }^{175}$ Securing a final agreement between the House and Senate was a wrenching process marked by partisan drama. As the August recess loomed, it seemed that conference negotiations had completely broken down when HVAC Chairman Miller balked at both the new funding requested by VA and the spending levels championed in the Senate by

vulnerable-democrats/.

${ }^{171}$ Brian Beutler, “The GOP’s Veterans Health Care Trap,” New Republic, June 1, 2014, accessed June 14, 2014, http://www.newrepublic.com/article/117966/gops-veterans-affairsscandal-politics-could-backfire.

${ }^{172}$ Crisis policies are responses to immediate problems that are perceived to be serious, that have burst on the policy makers with little or no warning, and that demand immediate action. Stephen E. Frantzich and Claude Berube, Congress: Games and Strategies, 333.

${ }^{173}$ In a June 5, 2014 press release SVAC Chairman Senator Bernard Sanders (I-VT) readily acknowledged that the bipartisan VA reform bill in the Senate that he authored with Senator John McCain (R-AZ), had language quite different than what he would have otherwise proposed. Senator Bernard Sanders, "Press Release: Sanders, McCain Reach Agreement on Veterans Bill,” June 5, 2014, accessed September 13, 2014, http://www.sanders.senate.gov/newsroom/press-releases/sanders-mccain-reach-agreement-onveterans-bill.

${ }^{174}$ Leo Shane III, "VA Reform Bills Stalled by Partisan Bickering.”

${ }^{175}$ Bridget Bowman, "VA Conference Committee Hopes for Quick Deal Despite High Price Tag,” Roll Call, June 24, 2014, accessed June 25, 2014, http://blogs.rollcall.com/wgdb/house-and-senate-meet-in-veterans-affairs-conferencecommittee/?dcz=. 
Chairman Sanders. Once again inserting himself into the VA debate, Speaker Boehner upped the partisan ante by nationalizing the dispute between the House and Senate, declaring that, "if President Obama cares about America's veterans, he needs to pick up the phone out in California and tell Senate Democrats to get to work.”176

The political standoff continued and created an anxious situation for many incumbents in both parties afraid of the political reverberations of the crisis on their campaigns. The tensions grew so high in the House that an unusual, bipartisan coalition of Members nearly preempted the policy preferences of the HVAC and its chairman by attempting a procedural end run around the House conference committee negotiators. The House narrowly defeated (205-to-207) a Democratic motion joined by 13 Republicans that instructed the House conferees for the VA reform legislation to adopt the more generous Senate-passed bill rather than wait to reach a compromise with the upper chamber. This insurgent effort nearly passed despite the HVAC Chairman's opposition. ${ }^{177}$

After a series of tense negotiations, the House and Senate ultimately reached a compromise agreement to support an eleventhhour reform bill that provided VA with \$16.3 billion. ${ }^{178}$ This legislation passed both houses with overwhelming majorities but provided a significantly lower spending level than either VA requested or that the Senate had supported. It also included language that greatly reduced the due process protections of VA SES employees against removal, long a highly partisan issue. While the near unanimous final vote tallies for P.L.

${ }^{176}$ Humberto Sanchez and Niels Lesniewski, "VA Talks Collapse,” Roll Call, July 24, 2014, accessed July 24, 2014, http://blogs.rollcall.com/wgdb/va-conference-on-verge-ofcollapse/.

177 Cristina Marcos, "House Narrowly Defeats Motion Agreeing to Senate VA Bill,” The Hill, July 24, 2014, accessed July 25, 2014, http://hehill.com/blogs/floor-action/house/213295house-narrowly-defeats-motion-agreeing-to-senate-va-bill.

${ }^{178}$ Leo Shane III, “\$16.3B VA Reform Bill Passes Senate 91-3; Obama Expected to Sign,” Military Times, July 31, 2014, accessed August 3, 2014, http://www.militarytimes.com/article/20140731/NEWS05/307310088/. 
113-146 look deceptively similar to previous major veterans bills, the open partisan warfare that engulfed its development and colored its final negotiations were yet further signs of the growing politicization of Federal veterans’ policy.

The road to P.L. 113-146 continued to expose growing policy differences within the VSO community. These were most evident in July 2014 when VA’s Acting Secretary requested \$17.6 billion in additional funds over three years for infrastructure improvements and the hiring of VHA clinicians. ${ }^{179}$ On July 23, sixteen VSOs and military advocacy groups penned a joint letter to the HVAC and SVAC supporting this request and asserting the "sacred obligation” of Congress to provide all necessary funding for VA. While the VFW, DAV, and IAVA were all signatories to this letter, the American Legion was conspicuously absent. ${ }^{180}$ The next day, Chairman Miller forcefully rebuked VA's request at an HVAC hearing where he asserted that "VA can no longer be considered a sacred cow." 181 On July 25, the Legion issued a joint statement with AMVETS and CVA declining to support VA's additional funding request. ${ }^{182}$ AMVETS and CVA were also the only VSOs to openly oppose S. 1982 earlier in the year. This statement was the Legion's second high profile policy break from the larger VSO community in two months and its second alliance with CVA, a conservative advocacy group heavily funded through the Koch Brothers’ political network.

${ }^{179}$ Rebecca Bratek, “Acting Chief of VA Says Agency Needs \$17.6 Billion to Fix Problems,” Los Angeles Times, July 16, 2014, accessed July 23, 2014, http://www.latimes.com/nation/nationnow/la-nn-na-va-bailout-hearing-20140716-story.html.

${ }^{180}$ Joint Letter from Major Veterans Organizations to Congressional Veterans Committee Leadership, July 23, 2014, accessed August 14, 2014, http://www.sanders.senate.gov/newsroom/press-releases/veterans-organizations-back-va-funding.

${ }^{181}$ Martin Matishak, “House Chairman Shreds VA’s 17.6B Request,” The Hill, July 24, 2014, accessed July 25, 2014, http://thehill.com/policy/defense/213220-house-chairman-shredsvas-176b-request.

${ }^{182}$ American Legion, “American Legion, AMVETS and CVA Joint Statement on \$17.6 Billion VA Spending Request,” The American Legion (website), July 25, 2014, accessed July 25, 2014, http://www.legion.org/veteranshealthcare/223535/american-legion-amvets-and-cva-jointstatement-176-billion-va-spending. 


\section{Part 3}

\section{Strategic Implications of Veterans Subgovernment Destabilization for VHA}

Although a deeply fractured Congress passed compromise legislation in the midst of the ongoing VA crisis, this action was not a continuation of the long-standing legislative deference to VA policy and budgetary priorities that had been the norm in Congress for decades. Indeed, while the traditional VSOs were highly visible and vocal during the debate surrounding P.L. 113-146, their efforts were not instrumental in securing its final passage. ${ }^{183}$ Election year political calculations within both parties were the primary catalyst for the process that led to a compromise bill that represented the actual policy preferences of few in Congress. ${ }^{184}$

Before the passage of P.L. 113-146, a veterans’ policy expert at a leading think tank suggested that current VA funding levels may represent the "high water mark” for national support of VA programs in an era of fiscal austerity and that fiscal constraints may force VA to do more with less or narrow the scope of its programs and services. ${ }^{185}$ This underscores the two competing visions for VA in the current political environment-an expansive VA directly providing a growing menu of comprehensive services or a narrower VA focused on smaller scope of programs. ${ }^{186}$ The first vision of an expanding VA is the traditional policy preference of the

${ }^{183}$ In a telephone conversation with the author on September 3, 2014, Dr. Norman Ornstein, explained that the passage of P.L. 113-146 was not VSO-driven and the process had little do with the VSOs or what they wanted. Congress was compelled to respond because of the broader political environment and a collective fear that a "do nothing Congress" narrative might take root in a midterm election year on an issue that received relentless media coverage for several months.

${ }^{184}$ Damian Paletta, Wall Street Journal, Economic Policy Reporter, interview by Pedro Echevarria, C-SPAN Washington Journal, June 7, 2014, accessed September 7, 2014, http://www.c-span.org/video/?319633-6/washington-journal-veterans-affairs-health-services.

185 Phillip Carter, Director of the Military, Veterans, and Society Program at the Center for a New American Security, Twitter post, July 24, 2014 (7:49 a.m.), accessed August 7, 2014, https://twitter.com/inteldump.

${ }^{186}$ Phillip Carter, interview by Leo Shane III, Defense One Forum, The New Battleground: Veterans, July 30, 2013, accessed August 7, 2014, http://www.defenseone.com/ideas/2014/07/live-stream-new-battleground-veterans/89963/. 
large VSOs while the more limited vision draws growing support from conservative legislators in Congress. Dr. Norman Ornstein of the American Enterprise Institute echoes this observation and notes that the tremendous budgetary pressures at the Federal level have created a "zero sum game” where, in the absence of a crisis, VA will be a recurring target for potential cuts or cost containment measures. ${ }^{187}$

As the 114th Congress dawns, VHA should expect most of the political and policy trends that characterized the 113th Congress to continue. As Senate control shifts to the Republicans, some features may be exacerbated, but the general contours will remain. The following four characteristics have the biggest implications for VHA as it prepares for the unstable policy environment of the 114th Congress and beyond: 1) a politically charged congressional oversight agenda will continue; 2) the political influence of mainstream VSOs will continue its decline, 3) long term shifts in veteran demographics will continue to change the policy environment, and 4) the calls for increased privatization of VA services will intensify. These trends and their implications for VHA appear below.

\section{A Politically Charged Oversight Agenda Will Continue in the 114th Congress.}

Events in the 113th Congress clearly demonstrate that VA no longer enjoys its traditional favored position in the eyes of Congress. Veterans' issues have joined other policy arenas as tools for playing out political conflict and pursuing partisan advantage. Furthermore, the tremendous budgetary pressures on Federal discretionary spending will bring added Congressional scrutiny of VA programs and the positions within Congress on this subject are sharply divided along party lines. ${ }^{188}$ There are few signs that these trends will change in the upcoming 114th Congress even with Republican control of the House and Senate.

\footnotetext{
${ }^{187}$ Dr. Norman Ornstein, telephone conversation with the author, September 3, 2014.

${ }^{188}$ Dr. Norman Ornstein, telephone conversation with the author, September 3, 2014.
} 
Virtually all electoral observers believe the House will remain in Republican hands for the remainder of the Obama administration and likely for some time afterwards. ${ }^{189}$ This makes divided government a given reality through at least 2017. Furthermore, the aggressive congressional oversight of VA led by HVAC will continue and may take on an even sharper tone in the 114th Congress. Under Republican House rules, Chairman Miller has two years remaining in his authorized six-year term as HVAC Chairman and the committee's staff and strategic approach should remain essentially unchanged. In a recent interview, the Chairman described HVAC’s continuing oversight when he cautioned that VA would have "no leash” going forward and he would ensure that "many eyes” would continue conducting oversight. ${ }^{190}$ A possible lesson drawn from the House's handling of veterans' issues in the 113th Congress is that new, aggressive tactics work in a once relatively nonpartisan policy arena and HVAC may “double down” on them as a result. The House leadership seem prepared to fully exploit this development by pledging far greater budgetary and staff support to HVAC than it normally enjoys. ${ }^{191}$ From a political standpoint, there are few, if any, incentives for the HVAC majority to work with the Obama administration on large-scale, collaborative VA legislation. ${ }^{192}$ There are, however, great political advantages for the committee to continue its expanded oversight activities and use its hearings and press operation to focus public attention on its drumbeat of VHA investigations.

${ }^{189}$ Nate Cohn, "Why Democrats Can’t Win: Thanks to Demographics, the Republicans Have a Virtual Stranglehold on the House,” New York Times, September 7, 2014, SR1.

${ }^{190}$ Rep. Jeff Miller, interview by Leo Shane III, Defense One Forum, The New Battleground: Veterans, July 30, 2013, accessed August 7, 2014, http://www.defenseone.com/ideas/2014/07/live-stream-new-battleground-veterans/89963/.

${ }^{191}$ Ed O’Keefe, "Problems at VA Still in Focus on Capitol Hill.”

192 Dr. Norman Ornstein explained this dynamic and noted his pessimism for the 114th Congress. He further observed that a primary political goal remains to deny the President bipartisan signing ceremonies to highlight the political divide. Dr. Norman Ornstein, telephone conversation with the author, September 3, 2014. 
The Senate's switch to Republican control will change the tone and policy agenda of SVAC, but the legislative impact for VA should not be as dramatic as the change of control in the House was after 2010. A Republican Senate can open a second front for politically charged oversight by SVAC, but structural considerations likely limit the passage of controversial veterans' legislation in the upper chamber. Even in an era of deep partisanship, the Senate remains an institution where, by its very design, individual members can exert great influence. ${ }^{193}$ The minority party in the Senate retains significant control over issues brought to the floor and this minority power was clearly evidenced in the February 2014 demise of S. 1982 that could not be passed even though a majority of senators supported its provisions. The Majority Leader is severely constrained by the power held by individual senators as well as the minority's collective power to stop legislation. ${ }^{194}$

In a Republican Senate, Senator Johnny Isakson (R-GA) is favored to assume the SVAC chairmanship in January 2015. He would succeed Senator Richard Burr (R-NC), the committee’s ranking member since 2009, as the Senate Republicans’ lead on veterans issues. ${ }^{195}$ While moderation has generally characterized Isakson's tenure on SVAC, there are signs that others within his caucus will pressure him to continue Senator Burr's adversarial posture towards VA in the 114th Congress. ${ }^{196}$ At a recent hearing, Burr cautioned the new VA Secretary that the committee’s aggressive oversight has “just begun.” ${ }^{197}$ During the 113th Congress, no senator was

193 Burdett A. Loomis and Wendy J. Schiller, The Contemporary Congress, $5^{\text {th }}$ ed., (Boston: Thomson Wadsworth, 2006), 159.

${ }^{194}$ Barbara Sinclair, Unorthodox Lawmaking: New Legislative Processes in the U.S. Congress, $4^{\text {th }}$ ed., 62, 73.

${ }^{195}$ Richard A. Oppel Jr., "Needing to Hire, Chief of V.A. Tries to Sell Doctors on Change,” New York Times, November 9, 2014, A18.

${ }^{196}$ Pete Kasperowicz, "Exclusive: John McCain Vows Tough Oversight of VA in GOPLed Senate,” The Blaze, November 7, 2014, accessed November 10, 2014, http:/www.theblaze.com/stories/2014/11/07/exclusive-john-mccain-vows-tough-oversight-ofthe-va-in-gop-led-senate/.

${ }^{197}$ Opening statement of Senator Richard Burr (R-NC), Hearing before the Senate 
more consequential in destabilizing the once collegial veterans' subgovernment than Burr. A long-time advocate of the modest privatization of some VHA services, he expanded his calls for private sector “competition” both publicly and privately in 2013 and 2014. ${ }^{198}$ Burr's working relationship with the SVAC Chairman, Bernard Sanders, became increasingly strained during the patient scheduling scandal and the chairman's attempt to forge bipartisan VA reform legislation with his ranking member went "nowhere." ${ }^{199}$ Sanders ultimately collaborated with a non-SVAC Republican, Senator John McCain (R-AZ), on the reform legislation that passed the Senate. ${ }^{200}$ Senator Burr's sharp criticism of the mainstream VSOs as defenders of VA and the status quo in a widely circulated open letter is perhaps his most lasting legacy as ranking member during the 113th Congress. ${ }^{201}$ This consequential action saw one component of the traditional veterans’ subgovernment “iron triangle” (Congress) explicitly criticizing another component (VSOs) for supporting the third (VA). Burr's repeated praise of the American Legion for breaking with other VSOs and demanding Secretary Shinseki’s ouster, may pressure other groups to modify their policy preferences to avoid losing access and influence with the committee's new majority. This strategic calculation by VSOs would even further destabilize the veterans’ subgovernment and place VHA in a more isolated policy position.

Committee on Veterans' Affairs, The State of VA Health Care, $113^{\text {th }}$ Cong., $2 d$ sess., September 9, 2014, accessed September 14, 2014, http://www.veterans.senate.gov/newsroom/minoritynews/ranking-member-burrs-opening-statement-for-state-of-va-health-care-hearing.

198 Jonathan Weisman, “Veterans Fire Back at Letter by Senator,” New York Times, May 27, 2014, A11.

199 Jonathan Weisman and Jennifer Steinhauer, "Senators Reach Accord Easing Worries Over Veterans’ Health Measure,” New York Times, June 6, 2014, A12.

200 Ibid.

201 James Kitfield, “Behind Eric Shinseki’s Downfall,” National Journal Daily, May 30, 2014, accessed July 7, 2014, http://go.galegroup.com/ps/i/do?id=GALE\%7CA369929919\&v=2.1\&u=97mwrlib\&it=r\&p=AO NE\&sw=w\&asid=568f3f48a3005ff0618c700c14efab1c. 
VSO Influence Will Continue to Decline and Diminish Their Role as Third Party Surrogates

VA should assume that the decline of mainstream VSO influence in Congress and the media will continue. The accelerating pressures on these organizations to stabilize membership will put them in increased competition with one another for earned media, a shrinking base of potential members, and a finite pool of philanthropy. This dynamic will further erode the traditional unity of purpose among the organizations. Although 2014 was a very consequential year in Congress for VA and veterans' issues generally, the traditional VSOs showed little ability to shape the political narrative or pressure Congress to pursue their policy preferences. Despite almost unanimous VSO support, the largest proposed expansion of VA programs to emerge from a congressional committee in a generation was subjected to a procedural filibuster in the Senate, an unprecedented act for a piece of veterans legislation. While Democratic strategists attempted to make a campaign issue out of Republican opposition to S. $1982,{ }^{202}$ there were no apparent political consequences for the incumbent senators that supported the bill's filibuster. ${ }^{203}$ Seeing that public opposition to VSO preferences in the 113th Congress was penalty free, senators may be emboldened to challenge veterans' groups again in the future.

The patient scheduling scandal also exposed a rift among the larger VSOs when the American Legion broke ranks with the VFW, DAV, and others by calling for Secretary Shinseki's resignation. The Legion's national commander later intimated at least part of his rationale when he suggested that this action increased awareness of the organization and could help attract new members and highlight its relevance to younger veterans. ${ }^{204}$ Even though VSOs

${ }^{202}$ For an example of the political messaging employed by Democrats following the filibuster of S. 1982, see "Mitch McConnell Votes Against Kentucky Veterans," Democratic Senatorial Campaign Committee, February 27, 2014, accessed September 4, 2014, http://www.dscc.org/pressrelease/mitch-mcconnell-votes-against-kentucky-veterans.

${ }^{203}$ No incumbent Republican senators running for reelection were defeated in 2014.

${ }^{204}$ Daniel M. Dellinger, “As Stewards of the Legion’s Future,” American Legion, September 2014, 8. 
rarely take such dramatic actions, the American Legion's decision suggests that there may be a new political incentive for breaking ranks with VA on high visibility issues. ${ }^{205}$ As Theda Skocpol observed, in an increasingly crowded universe of competing advocacy groups with narrow constituencies, groups have incentives to raise their voices. In the current media environment, the incentives for organizations to exploit drama and controversy often outweigh the modest benefits of coalition building. ${ }^{206}$ If Skocpol's theory is correct, this will adversely impact VHA because of its great reliance on VSOs as primary surrogates and advocates. As VSOs face increasing pressure to distinguish themselves in the media and among potential donors, they are less likely to maintain their traditional deliberative "wait and see” posture in crisis situations involving alleged VA wrongdoing.

The Increasing Geographic Disparity of America’s Veteran Population

An inexorable redistribution of America's veteran population has been underway for over four decades. This trend has multiple causes, but its primary drivers are the passing of the enormous World War II veteran cohort and the all-volunteer force (AVF) initiated in 1973. Since the advent of the AVF, the geographic distribution of servicemembers is comparatively unrepresentative of the nation as a whole..$^{207}$

Since their founding, the HVAC and SVAC were traditionally categorized as "uniform externality” committees, those committees whose jurisdictions affect all Members of Congress

${ }^{205}$ Senator Richard Burr (R-NC), the ranking member of SVAC, twice thanked the American Legion for breaking ranks other VSOs and calling for Secretary Shinseki's resignation. The first instance was his notorious open letter to VSOs in May 2014, and the second was in a speech at the 2014 American Legion national convention. When Republicans assume control of the Senate in January 2015, Burr's recent actions will directly inform the advocacy strategies of VSOs in the 114th Congress.

${ }^{206}$ Skocpol, Diminished Democracy, 236.

${ }^{207}$ Danielle Allen, “A Military that Reflects the Red-Blue Divide?,” Washington Post, December 15, 2008, accessed September 20, 2014, http://www.washingtonpost.com/wpdyn/content/article/2008/12/14/AR2008121401815.html. 
relatively evenly and whose policy preferences carry great influence within the larger caucus. ${ }^{208}$ If current demographic trends continue, this assumption will no longer be valid. As the variance of veteran population between individual congressional districts increases, the importance of veterans' issues among individual Members will remain constant in some districts while decreasing to the point of insignificance in others. As this happens, HVAC and SVAC may eventually transition to "mixed externality” committees such as the Armed Services or Agriculture committees that by the nature of their jurisdictions, have differing levels of interest from individual Members. To illustrate this trend, the veteran population of individual congressional districts is illuminating.

In 1970, all congressional districts had at least 24,000 veterans within their boundaries. ${ }^{209}$ At the start of the 113th Congress, nine of New York’s 27 congressional districts had fewer than 24,000 veterans. In contrast, all five of Oklahoma’s congressional districts had veteran populations greater than 63,000 and all eleven of Virginia's districts had more than $57,000 .{ }^{210}$ The impact of these numbers is even more revealing when one considers that the average congressional district contained just 465,000 people in $1970^{211}$ and had 710,767 in $2010 .{ }^{212}$

${ }^{208}$ Gary W. Cox and Matthew D. McCubbins, Legislative Leviathan: Party Government in the House, 193.

${ }^{209}$ Ibid.

${ }^{210}$ U.S. Department of Veterans Affairs, National Center for Veterans Analysis and Statistics, Table 10L: VETPOP2011 Living Veterans by Age Group, 113th Congressional District, Gender, September 30, 2010, accessed September 4, 2014, http://www.va.gov/vetdata/Veteran_Population.asp.

${ }^{211}$ U.S. Department of Commerce, Social and Economic Statistics Administration, Bureau of the Census, 1970 Population of Congressional Districts for the $93^{\text {rd }}$ Congress, October 1972, 2.

${ }^{212}$ Sandhya Somashekhar and Aaron Blake, "Census Data Realigns Congressional Districts in Key Political States,” Washington Post, December 21, 2010, accessed September 4, 2014, http://www.washingtonpost.com/wpdyn/content/article/2010/12/21/AR2010122103084.html. 
This shift in veteran density influences the regional mix of Members who place a high priority on veterans' issues and ultimately narrows the ideological range of political actors substantively engaged in them. For example, Members representing liberal constituencies most inclined to support the success of a robust government-owned and operated health care delivery system such as VHA have little political incentive to immerse themselves in VA issues because of the rapidly vanishing veteran population in those areas. This ideological imbalance compared to Congress as a whole, is evident on HVAC where only two of the Democrats (18\%) serving in 2014 are members of the Congressional Progressive Caucus (CPC), the umbrella group for liberal Members within the Democratic House caucus, while 66 of the 199 House Democrats overall (33\%) belong to the CPC. ${ }^{213}$

The regional disparity of veteran population and its corresponding local influence on Members will only grow in the coming decade. In 2010, New Jersey held the distinction of being the first state where more than half of the veteran population was over the age of 65 . By September 2014, VA projected that Connecticut, New York, Massachusetts, Michigan, New York, Pennsylvania, and Rhode Island all joined New Jersey at this demographic tipping point. ${ }^{214}$ These eight states hold 87 congressional districts - 20 percent of the entire 435-member body and are on the demographic glide path for veterans holding greatly reduced political influence with elected officials. VA projects that by 2024, 30 current congressional districts will have fewer than 15,000 living veterans and at least 78 will have fewer than 24,000 - the lowest number of any congressional district in $1970 .{ }^{215}$ The consequences of this regional imbalance and the

213 “Membership,” House Committee on Veterans’ Affairs, accessed September 11, 2014, http://veterans.house.gov/about/membership; “Caucus Members,” Congressional Progressive Caucus, accessed September 11, 2014, http://cpc.grijalva.house.gov/caucus-members/.

${ }^{214}$ U.S. Department of Veterans Affairs, Table 10L: VETPOP2011 Living Veterans by Age Group, 113th Congressional District.

${ }^{215}$ U.S. Department of Veterans Affairs, Table 10L: VETPOP2011 Living Veterans by Age Group, 113th Congressional District. 
geographic diversity of who serves on the veterans' committees are profound and already evident in the 113th Congress. Only two of the 25 HVAC members, both Republicans (8\%), hail from the eight states currently projected to have a majority of veterans over 65. In the Senate, Senator Richard Blumenthal (D-CT) is the sole representative of these states on the fourteen-member SVAC panel (7\%) even though they comprise $16 \%$ of the chamber's seats overall. ${ }^{216}$

\section{Calls for Increased Privatization of VHA Services will Grow in Intensity}

Phillip Longman of the New America Foundation, an expert on veterans’ health policy, describes parts of P.L. 113-146 as a "trojan horse" for the further privatization of VHA, currently the largest integrated health care system in the United States with an appropriated medical care budget approaching $\$ 60$ billion annually. ${ }^{217}$ As congressional calls grow louder to send more VA patients for care in the private sector and corporate lobbying efforts expand, VHA's sizeable budget presents an attractive target for health care organizations seeking to expand their veterans' business lines. Several of these corporations, namely TriWest Healthcare Alliance and United Healthcare, already provide care for some VA patients and could see a substantial growth in referrals depending on how new legislative authorities provided under P.L. 113-146 are implemented.

Recognizing the possibilities for private sector growth within the veterans' health sphere, health care organizations and industry groups are spending significant money for high visibility sponsorships, lobbying, and political action committees (PACs). For example, TriWest and United Healthcare both provide significant financial support to several newer veterans

216 "Membership,” House Committee on Veterans Affairs; “Committee Members,” Senate Committee on Veterans’ Affairs, accessed September 11, 2014, http://www.veterans.senate.gov/.

${ }^{217}$ Danny Vinik, “The VA Reform Legislation is a 'Trojan Horse' for Privatization,” The New Republic, June 13, 2014, accessed June 14, 2014, http://www.newrepublic.com/article/118150/veterans-affairs-bill-congress-could-undermine-notfix-va. 
organizations, most notably the IAVA; it reported receiving at least $\$ 500,000$ from TriWest alone in 2012. ${ }^{218}$ Between April and June 2014, the American Hospital Association (AHA) spent at least \$60,000 in direct lobbying expenses in favor of the legislation that became P.L. 113-146 and created a pilot program for increased private sector referrals. ${ }^{219}$ Besides the AHA, over 30 other organizations formally lobbied for this legislation including United Health and the Hospital Corporation of America (HCA). ${ }^{220}$ The recent lobbying activities of these groups and campaign contributions from their related PACs, reveal a growing corporate interest in veterans' health care as the long taboo discussion of VHA privatization becomes politically acceptable.

Congress always had Members that favored the privatization of VHA services, but they muted their preferences because of the perceived political consequences of openly advocating that position. ${ }^{221}$ The major VSOs vehemently opposed privatization and that opposition was enough to preempt any serious discussion of the matter within Congress. Tellingly, in the Clinton administration, The Heritage Foundation, a group that traditionally advocates against Federal largess, did not even make an effort to advocate VA privatization because the proposition had no support in Congress, at least publicly. ${ }^{222}$ This assumption first began to change during the 2010 election cycle when Rep. Bill Flores (R-TX) ran against incumbent Rep. Chet Edwards (D-TX), the Chairman of the House Appropriations Committee’s MILCON-VA Subcommittee. Flores openly campaigned for the expanded use of private sector options for VHA patients and soundly

${ }^{218}$ Leading at Home: IAVA 2012 Annual Report.

${ }^{219}$ The Nickles Group, LLC, LD-2 Lobbying Report (on behalf of American Hospital Association), ${ }^{\text {nd }}$ Quarter 2014, July 17, 2014, accessed September 20, 2014, http://soprweb.senate.gov/index.cfm?event=getFilingDetails\&filingID=F800B3EE-093D-47A4933F-A25A4D4D4940\&filingTypeID=60.

220 “Clients Lobbying on H.R. 4810: Veteran Access to Care Act of 2014,” Center for Responsive Politics, Open Secrets, accessed September 20, 2014, https://www.opensecrets.org/lobby/billsum.php?id=hr4810-113.

${ }^{221}$ Danny Vinik, “The VA Reform Legislation is a 'Trojan Horse’ for Privatization.”

${ }^{222}$ William Safire, “Sacred Cow, II,” New York Times, January 19, 1995, A23. 
defeated Edwards, a ten-term incumbent who was one of VA's most vocal champions in Congress and enjoyed deep VSO support. ${ }^{223}$ Flores assumed a position on HVAC upon his 2011 arrival in Congress, and since then a growing number of the panels' members have advocated for the limited privatization of some VHA services. Several senators including Richard Burr (R-NC), the SVAC ranking member, have expressed similar sentiments. ${ }^{224}$ P.L. 113-146's authorization of a temporary, two year pilot to significantly expand the use of non-VA care is evidence of how what were once considered extreme positions now enjoy growing acceptance in Congress. In fact, less than two months after P.L. 113-146 became law, at least one member of the HVAC began advocating for the permanent extension of its two year pilot provision. ${ }^{225}$

For their part, all of the major VSOs continue to support VHA remaining a comprehensive government-owned/government-operated health care organization. ${ }^{226}$ Over the last three decades, this position alone was sufficient to thwart any serious attempts to significantly privatize VHA. The consistency of the VSOs’ support for a robust VHA is unquestioned, but developments in the 113th Congress prompt questions as to how effectively they can block future efforts to expand privatization initiatives, especially those backed by corporate lobbying and PAC

${ }^{223}$ Michael W. Shapiro, "McCain Defends Flores’ Support of Private Health Care Option for Veterans,” Waco Tribune, October 5, 2010, accessed September 20, 2014, http://www.wacotrib.com/news/mccain-defends-flores-support-of-private-health-care-optionfor/article_0b75569d-5ac4-5ef3-870d-522bbd391b1f.html?mode=jqm.

${ }^{224}$ In a May 15, 2013 meeting with then VHA Under Secretary Robert Petzel, Senator Burr emphasized his preference for VHA to increase its use of private sector health care. He further requested that VHA explore the feasibility of having a large health care center under construction in North Carolina operate as a contract facility. This site from its inception was planned to operate as a VHA staffed center.

${ }^{225}$ Rep. Tim Huelskamp (R-KS) endorsed the permanent expansion of this pilot during a September 17, 2014 HVAC hearing. Hearing before the House Committee on Veterans Affairs, Scheduling Manipulation and Veteran Deaths in Phoenix: Examination of the OIG's Final Report, $113^{\text {th }}$ Cong., 2nd sess., September 17, 2013, accessed on September 20, 2014, http://www.c-span.org/video/?321497-4/phoenix-va-inspector-generals-report-panel-2.

${ }^{226}$ Virgil Dickson, “Senate Proposal to Give Veterans Private Care Carries Big Price,” Modern Healthcare, June 13, 2014, accessed June 14, 2014, http://www.modernhealthcare.com/article/20140613/NEWS/306139939. 
dollars. Events in 2014 showed the willingness of many legislators to openly challenge VSO preferences on S. 1982 and VA supplemental funding as well as the fragmentation of the VSO community on at least two major policy issues. These events and the VSOs' uneven ability to shape them may further embolden privatization proponents in both Congress and the corporate sector.

The ideological narrowing of veterans' committee membership discussed earlier could also contribute to an environment more favorable to the privatization advocates. A center-right committee composition, where liberal voices are underrepresented or absent altogether, may be more receptive to privatization proposals and there will be few countervailing voices at the committee-level to challenge them or moderate their scope. Political science literature suggests that in a policy subgovernment environment, even small biases in committee representation can aggregate into large changes in the law. ${ }^{227}$

${ }^{227}$ Ken Kollman, "Inviting Friends to Lobby: Interest Groups, Ideological Bias, and Congressional Committees,” American Journal of Political Science 41, no. 2 (April 1997): 519544, 522. 


\section{Part 4 \\ Options for VHA in an Increasingly Unstable Policy Environment}

The increased politicization of veterans' issues in Congress and the diminished role of the VSOs that traditionally rallied support for VA’s budget and program priorities have destabilized the veterans' subgovernment. In a departure from the traditionally closed "iron triangle," congressional power now grows within the subgovernment alongside new, professionally run veterans' organizations heavily backed by corporate dollars while VHA's ability to shape the narrative weakens. To navigate this changed policy environment, VA must transform its approach to congressional relations similar to the way it successfully transformed its approach to health care delivery in the 1990s.

As the nation's largest integrated health care delivery system, VHA is a learning organization. Its complexity provides it with the inherent institutional traits necessary to reframe its interactions with other elements of the veterans’ subgovernment. Dr. Kenneth Kizer, VHA’s renowned former Under Secretary for Health who led its transformation in the 1990s, observes that health care organizations are complex, adaptive systems governed by the rules of complexity theory. He argues that health care change agents must understand this. ${ }^{228}$ Health care entities like VHA are complex adaptive systems because they contain groups that seek to adapt. When multiple groups are adapting to one another, there is a process of dynamic interactions. This makes it difficult to predict the consequences of an action because each change of strategy alters the context within the next change will be tried and evaluated. ${ }^{229}$ The forces that shape events do not work in a simple, additive fashion, instead they are non-linear where a few small events can produce a big effect if their impacts multiply rather than add. ${ }^{230}$

${ }^{228}$ Kenneth W. Kizer and R. Adams Dudley, "Extreme Makeover: Transformation of the Veterans Health Care System,” Annual Review of Public Health 30 (2009): 18.1-18.27, 18.16.

${ }^{229}$ Robert Axelrod and Michael D. Cohen, Harnessing Complexity: Organizational Implications of a Scientific Frontier (New York: Basic Books, 2000), 9-10.

${ }^{230}$ Ibid., 14. 
In its current state, VHA sits within a larger complex adaptive system, the veterans'

policy subgovernment. As demonstrated by the many consequential events that stemmed from an initial congressional investigation into scheduling improprieties at a single VHA facility, the impact of individual events within the subgovernment are increasingly unforeseeable and nonlinear. While VHA utilized complexity theory to improve its health care delivery system, it has not applied those lessons to guide its interactions with external stakeholders, particularly a skeptical Congress. As clearly destabilizing and non-linear trends emerged in its interactions with legislators and VSOs during the 113th Congress, VHA (at the direction of VA OCLA) did not properly assess the changed policy environment it operated in.

A 2014 White House report written in the wake of the patient scheduling scandal identified VA's lack of agility in responding to oversight requests, the absence of proactive engagement to oversight bodies, and inadequate capacity at the VHA leadership level to manage crises. ${ }^{231}$ As congressional oversight requests multiplied and grew in intensity during the 112th and 113th Congresses, VHA and VA OCLA tightened their control over internal response systems designed for an earlier era characterized by a more collegial and closed subgovernment. Processes never designed for a continuous media environment or the congressional politicization of veterans' health care were rapidly overwhelmed and slowed responses at the very time more agile procedures were needed. ${ }^{232}$ By early 2014, this created a VA headquarters culture described

${ }^{231}$ Executive Office of the President, Issues Impacting Access to Timely Care at VA Medical Facilities, June 27, 2014, accessed August 14, 2014, http://www.whitehouse.gov/sites/default/files/docs/va_review.pdf.

${ }^{232}$ By late 2013, the VA clearance process for even the most routine and noncontroversial congressional requests was rigid and unsuited for the dynamic operating environment. VHA responses were prepared in hard copy folders and reviewed in-person by an SES-level reviewer. After VHA clearance, responses were sent electronically to OCLA who reconfigured them again into hard copy folders for personal review by the Assistant Secretary for Legislative Affairs. Requests as simple as the list of services available at an individual VAMC or the anticipated opening date of a clinic were subjected to this level of OCLA review. 
as being in "chronic crisis mode ... chronic panic ... constant damage control.”"233 When systems get tightened in this manner, complexity theory suggests that they become more vulnerable to disruptions. ${ }^{234}$ Policy leaders must continually anticipate how the environment they operate in will change by the actions of actors. They must also leave themselves room to respond if their anticipations are incorrect. ${ }^{235}$ In failing to recognize trends in the veterans' subgovernment and adjusting accordingly, OCLA, and by extension, VHA, were not prepared for the onslaught of scrutiny unleashed by the patient scheduling scandal. Any strategy that does not incorporate change is not just a poor strategy; it is no strategy at all. ${ }^{236}$

As detailed in Part 3, the destabilization trends within the veterans' subgovernment are substantial and will likely intensify. VHA must recognize its changed policy environment as one characterized by increased uncertainty and adapt accordingly. By leveraging its proud culture as a learning organization, VHA can evaluate its subgovernment as a complex adaptive system and make adjustments to position it for the challenges and uncertainty that lie ahead. Outlined below are four possible options for VHA to better adapt to these destabilization trends. They can be implemented individually or comprehensively at relatively little cost: 1) changing from a primarily reactive to proactive congressional engagement policy, 2) decentralizing VHA's congressional engagement authority to foster adaptability and agility, 3) maximizing the use of VHA's local leaders to build relationships with legislators, and 4) cultivating additional third party surrogates for VHA to supplement the VSOs.

${ }^{233}$ Aaron Glantz, Center for Investigative Reporting, interview by Mitch Jeserich, Pacifica Radio Letters and Politics, May 28, 2014, accessed July 5, 2014, https://www.kpfa.org/archive/id/103217.

${ }^{234}$ Robert Jervis, System Effects: Complexity in Political and Social Life (Princeton, NJ: Princeton University Press, 1997), 294.

235 Ibid.

${ }^{236}$ Everett C. Dollman, Pure Strategy: Power and Principle in the Space and Information Age (London: Frank Cass, 2005), 126. 
Changing VA’s Traditionally Reactive Congressional Engagement Posture

The relatively closed nature of the post-WWII veterans' subgovernment fostered an environment where VA proactively engaged a narrow set of stakeholders compared to other Federal agencies. In Congress, its primary traditional audience consisted of the "four corners," the members of the House and Senate veterans' committees and their staff. Engagement with other congressional audiences was generally reactive in nature, episodic, and not tied to a coordinated outreach strategy. ${ }^{237}$ As Congress adopted a sharper tone towards VA in the 112th and 113th Congresses, VHA attempted to expand its proactive congressional outreach. These requests were given an extremely low priority by OCLA and fell victim to pressing, reactive actions. ${ }^{238}$ This restrained engagement posture became a growing liability as events thrust VA into the modern congressional arena. Instead of expanding the range of stakeholders it interacted with, between 2009 and 2014 VA’s OCLA progressively implemented internal processes that further limited those interactions. ${ }^{239}$

${ }^{237}$ This point primarily concerns VA's congressional engagements in Washington, DC. Local VA facilities conduct countless events with their respective legislators, but these are almost exclusively planned at the facility level and not tied to any larger strategy. In many instances, VACO is not notified of these events until after they occur and this results in missed messaging opportunities.

${ }^{238}$ There are numerous examples throughout the 112th and 113th Congresses where VHA asked OCLA to schedule proactive engagement meetings with Members of Congress on a range of issues, to include emerging areas of congressional interest. These requests were given very low priority and were either never scheduled or scheduled months after being proposed, thus limiting their effectiveness and ability to shape the environment.

${ }^{239}$ Beginning in 2009, OCLA implemented a series of informal policies that reduced VHA's ability to engage congressional stakeholders. First, OCLA prohibited VHACO personnel at all levels from interacting with congressional staff absent prior OCLA coordination and participation. Second, OCLA staff-level personnel regularly denied or delayed VHACO requests for briefings, meetings and phone calls with Congress further limiting proactive engagement. Finally, OCLA came to require the full clearance of talking points and briefing materials through its senior political leadership before it would attempt to schedule an event between VHA and Congress, even in cases where Congress requested the meeting. By the 113th Congress, these requirements meant that weeks often passed between VHA's request for a meeting with Congress and its approval/scheduling or denial by OCLA. This contributed to a delayed flow of information and feedback that increasingly antagonized congressional overseers. 
The 2014 patient scheduling scandal ably demonstrates the cumulative vulnerability of a limited outreach strategy with Congress in an uncertain policy environment. As the media coverage and public outcry grew following the disclosure of improprieties at VAPHCS and other facilities, VHA had a very limited bench of knowledgeable congressional surrogates familiar with its programs and how they compared to national health care trends. While the scandal narrative developed by HVAC and its press operation became widely accepted on Capitol Hill, there was no informed counterweight within the House and a very ineffectual one in the Senate because of the SVAC's limited staff resources. An agency cannot develop informed and effective surrogates in the midst of a crisis, especially after seeds of doubt are sown about its integrity and commitment to transparency.

Looking back at events throughout 2013 and HVAC’s increasingly aggressive oversight campaign, VA OCLA should have anticipated the emergence of an event like the Phoenix story attracting highly negative and sustained attention from Congress. HVAC’s Phoenix investigation was only one in a series of potentially damaging inquests that received media coverage, the key differences were the intensity and duration of interest it generated. Chairman Miller himself expressed surprise that the Phoenix story gained the traction that it did. ${ }^{240}$ After more than a year of increasingly bruising HVAC oversight investigations, VA was still unprepared to manage the political or media fallout from a high profile scandal. Complexity theory suggests that politics, like nature seldom returns to the status quo after a dispute or policy action, but rather those events transform the political landscape and create niches for new actors and disputes, often in unanticipated ways. ${ }^{241}$

In the wake of the appointments scandal, Members beyond the narrow confines of the veterans’ committees are beginning to immerse themselves in policy issues that impact VHA;

\footnotetext{
${ }^{240}$ Ed O’Keefe, "Problems at VA Still in Focus on Capitol Hill.”

${ }^{241}$ Robert Jervis, System Effects: Complexity in Political and Social Life, 50.
} 
most, for the very first time. It is essential that VA seize the opportunity to engage and educate this broader universe of stakeholders before the next crisis emerges or controversial legislation reaches the floor. Sustained outreach by VHA beyond the traditional "four corners" is imperative for four primary reasons: 1) a broader array of stakeholders with greater institutional influence must be informed of VHA programs and policy priorities; 2) congressional health policy experts need a better understanding of VHA; 3) VHA needs to educate those stakeholders experiencing dramatic declines in veteran population and VSO influence; and 4) to familiarize a wider ideological spectrum in Congress about VHA than that currently represented on HVAC and SVAC.

As discussed above, the HVAC and SVAC are low prestige committees with more pronounced consequences for VHA in the House than the Senate. The roster of HVAC members in the 113th Congress clearly underscores this reality as the majority of its Democrats are freshmen and on the Republican side, only Chairman Miller has more than four terms in the House. Rep. Jim Cooper (D-TN), a twelve term House veteran, recently characterized HVAC members as "green and inattentive” and “most don't know how [the VA system] works.” ${ }^{242}$ To compound this general inexperience, Cooper notes that the limited fundraising opportunities on HVAC prompt its members to leave for other committees once they have the opportunity. ${ }^{243}$ This vicious cycle of turnover on HVAC deprives VHA of a meaningful roster of informed congressional advocates at a time when its programs are subject to unprecedented partisan scrutiny and unusual budget constraints. As House debates over VA increasingly go beyond the HVAC, VHA suffers because there is little informed counterweight to the committee's narrative. A concerted effort of strategic engagement and outreach to key senior Members of Congress who do not serve on HVAC could elevate the overall understanding of VA health care within the

\footnotetext{
${ }^{242}$ Ryan Grim, “Here’s the Simple Reason Congress Hasn’t Fixed The VA.” ${ }^{243}$ Ibid.
} 
House. This expanded engagement would be relatively simple to execute because VHA operates facilities in most congressional districts and that is an obvious leverage point to earn and sustain the attention of key Members of Congress.

Although VHA is the nation's largest integrated health care system, it does not fall under the jurisdiction of the congressional committees with oversight of most health policy issues, the House Committee on Energy \& Commerce and the Senate Committee on Health, Education, Labor and Pensions (HELP). Since the less influential HVAC and SVAC oversee VA, many health policy experts within Congress are remarkably uninformed about VHA. Without a coordinated effort to engage these influential health policy audiences, VHA will not benefit from their expertise or authority when it draws attention, either positive or negative, in their respective chambers. An established relationship with House Energy \& Commerce or Senate HELP may have resulted in better-informed congressional debate in the immediate aftermath of the Phoenix revelations. At the very least, respected congressional health policy hands conversant about VHA could have shaped the contours of the discussion by explaining that VA's struggle to ensure timely patient access also challenges the private sector. ${ }^{244}$ Senator Bernard Sanders (I-VT), the SVAC Chairman in the 113th Congress who also sits on HELP, shows the strategic potential of expanded VHA outreach to the health policy community. With seats on HELP and SVAC, Sanders tried to use his vast knowledge of VHA and health care generally to put VHA's problems within the context of larger challenges faced by the American health care system. The Senator made nuanced arguments on several occasions, but was only one voice among many because of his rare combination of policy expertise. ${ }^{245}$ Efforts to increase the number of health policy voices

${ }^{244}$ Senator Bernard Sanders (I-VT), interview by Greta Wodele Brawner, C-SPAN Newsmakers, May 22, 2014, accessed August 7, 2014, http://www.C-span.org/video/?3195221/newsmakers-sen-bernie-sanders-ivt.

${ }^{245}$ Senator Bernard Sanders (I-VT), interview by Greta Wodele Brawner, C-SPAN Newsmakers, May 22, 2014. 
also familiar with VHA could elevate the level of informed discourse when VHA inevitably finds itself under scrutiny again in the 114th Congress. ${ }^{246}$

Earlier sections of this monograph outlined the negative membership trends among large VSOs, their waning influence and Congress, and the disproportionate projected drop in veteran population by region. As veteran density rapidly drops in large swaths of the Northeast and upper Midwest, the ability of VSOs to influence Members from those areas dissipates. Even in those areas with steep drops in veteran population, VHA still provides services and maintains a presence. It needs to strategically build rapport and cultivate stakeholder relationships in all regions, but this role is especially critical in those areas where VSOs do not enjoy the visibility or influence they once did. With VHA now subject to the political trends long faced by other agencies, awareness of its programs by the greatest number of legislators becomes increasingly important. As certain regions experience precipitous declines in veteran population, VHA needs to increase its communications with relevant elected officials to ensure awareness and relevance.

The growing regional disparity in veteran population lowers the incentive for a wider spectrum of Members to seek appointments on the veterans’ panels. As illustrated in Part 3, the composition of HVAC and SVAC in the 113th Congress already indicates an underrepresentation of the eight states where the veteran population is already projected to be oldest. The implications for this underrepresentation transcend regional diversity and extend to the ideological diversity of the veterans' panels and, by extension, the breadth of perspectives represented in the development of veterans' policy. Of the eight states with the oldest veteran population and currently

${ }^{246}$ This responsibility sits with VA and will require the dedication of resources in the House where familiarity with VHA and expertise in national health policy are a structurally rare combination because of House rules. The Committee on Energy \& Commerce is an exclusive membership committee and its members need a waiver from leadership to serve on a second committee. As a result, the true health policy expertise in the House is concentrated on E\&C. It is only shared with other panels in rare exceptions through its handful of members authorized to sit on additional committees. 
underrepresented on HVAC and SVAC (discussed in Part 3), none have been carried by a Republican presidential candidate since $1988 .{ }^{247}$ This is significant because it demonstrates the increasingly low incentive for legislators from reliably Democratic constituencies to serve on the veterans' committees, particularly HVAC. The relative absence of legislators from these regions narrows the ideological range of elected officials that regularly interact with VA leaders. An expanded VHA congressional engagement strategy can involve a fuller range of perspectives in the development of veterans’ policy and potentially generate a broader array of options in Congress.

Congressional Engagement Authority Can be Decentralized and Adaptability Fostered In recent congressional testimony before HVAC, VA Secretary Robert McDonald acknowledged the problems with VA’s rigidly centralized approach to congressional communications and its contribution to delaying VHA's information flow to Congress and exacerbating an adversarial environment within the veterans’ subgovernment. The Secretary offered support for Chairman Miller's desire ${ }^{248}$ to restore the authority of VHA officials to communicate with Congress directly. ${ }^{249}$ McDonald's commitment to repairing the Department's strained relationship with Congress is promising and could be the starting point for a prudent decentralization of VA's congressional interactions. The restoration of VHA's autonomy to develop an organic congressional engagement strategy will give the nation’s largest integrated

${ }^{247}$ U.S. National Archives and Records Administration, U.S. Electoral College Historical Election Results, accessed September 26, 2014, http://www.archives.gov/federalregister/electoral-college/historical.html.

${ }^{248}$ Rep. Jeff Miller, interview by Leo Shane III, Defense One Forum, The New Battleground: Veterans, July 30, 2013, accessed August 7, 2014, http://www.defenseone.com/ideas/2014/07/live-stream-new-battleground-veterans/89963/.

${ }^{249}$ Robert A. McDonald, Secretary of Veterans Affairs, Hearing before the House Committee on Veterans Affairs, $113^{\text {th }}$ Cong., 2d sess., September 17, 2014, accessed September 20, 2014, http://www.c-span.org/video/?321497-4/phoenix-va-inspector-generals-report-panel-2. 
health care system the agility to respond promptly to congressional concerns. The current restrictive processes for VHA congressional engagements are hierarchical and heavily dependent on the responsiveness and approval of other VA entities. VHA’s rigid and asymmetric relationship with OCLA increases the complexity of executing small and slow adjustments to changed circumstances when they are appropriate. ${ }^{250}$

The extreme centralization of VA’s congressional engagement activities by Joan Mooney, the Assistant Secretary for Congressional and Legislative Affairs between 2009 and 2014, adversely impacted VHA’s ability to develop effective engagement plans or adaptively respond to a changing policy environment. VA Directive 8100, issued in 1996 and still in effect, prescribes the conceptual framework for VA’s congressional relations activities. A plain reading of the directive clearly identifies OCLA as VA's focal point for interactions with Congress but reserves wide latitude for VHA and other components to communicate independently with congressional officials and schedule meetings or briefings. ${ }^{251}$ However, Assistant Secretary Mooney adopted a much narrower interpretation of the document and, through a series of verbal instructions, progressively constrained the autonomy of VHA leaders to interact with Congress. ${ }^{252}$

${ }^{250}$ Robert Jervis, System Effects: Complexity in Political and Social Life, 19-20.

${ }^{251}$ Under VA Directive 8100, VHA is required to notify OCLA of all personal contact with Congress involving legislation, Department-level policy, and politically or otherwise sensitive matters. It is further required to notify OCLA of all scheduled meetings between VHACO personnel, members of Congress, or congressional staff. A plain reading of the directive provides VHA autonomy to schedule meetings without OCLA pre-approval. Department of Veterans Affairs, VA Directive 8100 - Guidance Relating to Congressional Relations Activities, March 24, 1996.

${ }^{252}$ OCLA implemented a series of informal policies that reduced VHA's ability to engage congressional stakeholders. First, OCLA prohibited VHACO personnel from interacting with Congressional staff absent prior OCLA coordination and participation. Second, OCLA staff-level personnel regularly denied or delayed VHACO requests for briefings, meetings and phone calls with Congress further limiting proactive engagement. Finally, OCLA came to require the full clearance of talking points and briefing materials through its senior leadership before it would even attempt to schedule an event between VHA and Congress, even in cases where Congress requested the meeting. By the 113th Congress, these requirements meant that weeks often passed between VHA's request for a meeting with Congress and its approval/scheduling or denial by OCLA. This contributed to a delayed flow of information and feedback that ultimately 
By the time the patient scheduling scandal broke in 2014, VHA headquarters officials had ceded virtually all control over their congressional relations strategy to OCLA. The centralization of VHA’s congressional affairs activities within an external, Department-level organization resulted in the proliferation of internal coordination procedures that further delayed the responses to congressional inquiries and execution of briefings. ${ }^{253}$ These delays grew at the same time VA came under growing public criticism from HVAC for its perceived unresponsiveness to Congress. ${ }^{254}$ Writers on organizational culture note that over-proceduralization inhibits critical thinking and creativity that are essential to finding a timely solution to complex problems.

Recourse to procedure cannot take the place for analysis when operating in an unstable environment. ${ }^{255}$

Since VHA became totally dependent on OCLA intermediaries for coordinating even the most routine interactions with its oversight committees in the 113th Congress, it fell into a phenomenon of complexity theory known as "following the agent." ${ }^{256}$ In this situation, VHA's dependence on OCLA had negative consequences because growing congressional frustration with

\section{antagonized congressional overseers.}

${ }^{253}$ OCLA’s 2014 Federal Employee Viewpoint Survey results offer an interesting window into the rigid climate within that organization during the height of the Phoenix scheduling crisis. 28 OCLA employees took the survey between May 5, 2014 and June 13, 2014. Only $2.8 \%$ of survey respondents positively responded to the statement, "employees have a feeling of personal empowerment with respect to work processes.” $67.9 \%$ of responses were negative. This compares to a $39.9 \%$ positive and $34.8 \%$ negative response rate to VA Central Office employees overall. These findings align with the author's personal observations that OCLA leadership fostered an exceptionally closed and inflexible culture between 2009 and 2014.

254 "VA Official Evades Questions from Congress,” The American Legion (web site), September 19, 2013, accessed September 2, 2014, http://www.legion.org/legislative/217183/vaofficial-evades-questions-congress.

${ }^{255}$ Mark D. Mandeles, “Imposing Order on Chaos: Establishing a JTF Headquarters,” Joint Center for Operational Analysis Journal XII, no. 2 (Summer 2010): 21-32.

${ }^{256}$ Robert Axelrod and Michael D. Cohen, Harnessing Complexity: Organizational Implications of a Scientific Frontier, 87. 
OCLA by extension eroded VHA's reputation on Capitol Hill. ${ }^{257}$ The tight restriction on those individuals authorized by OCLA to communicate directly with Congress contributed to another consequence of agent following, the loss of informational diversity and contextual feedback available to VHA officials. The majority of VHA's strategic and operational insights on Congress' oversight agenda in the 113th Congress were second hand and filtered through OCLA agents who often lacked the specialized health care expertise or institutional memory to place them in proper context. ${ }^{258}$

A decentralization of congressional liaison activities can provide VHA and VA generally with greater carrying capacity to communicate with Congress and respond to stakeholder concerns. In complexity theory, negative feedback will appear when a system applies a strategy without consideration of its carrying capacity. ${ }^{259}$ This was certainly the case during the 113th Congress when OCLA tightly restricted interactions with Congress at a time of surging requirements. The negative feedback came in the form of bipartisan frustration and unprecedented oversight hearings exploring VA's perceived unresponsiveness to Congress. ${ }^{260}$ If VHA regains even the modest autonomy to respond to non-sensitive congressional requests and

\footnotetext{
${ }^{257}$ Robert Axelrod and Michael D. Cohen, Harnessing Complexity: Organizational Implications of a Scientific Frontier, 90.

${ }^{258}$ The personnel turbulence within OCLA between 2010 and 2013 was a recurring concern for the author. The OCLA staff assigned to issues frequently changed and this contributed to a diminished institutional knowledge on issues of high congressional interest. Since OCLA Assistant Secretary Joan Mooney prohibited VHACO personnel from direct phone or e-mail contact with congressional staff, VHA programs were dependent on the ability of individuals largely unfamiliar with issues and their history to communicate with Congress and interpret their information requests.

${ }^{259}$ Jamshid Gharajedaghi, Systems Thinking: Managing Chaos and Complexity: A Platform for Designing Business Architecture (Burlington, MA: Butterworth-Heinemann, 2006), 116.

${ }^{260}$ Hearing Before the House Committee on Veterans Affairs, Trials in Transparency: An Analysis of VA Cooperation with Congress in Meeting its Oversight Responsibilities on Behalf of Veterans, $113^{\text {th }}$ Cong., $1^{\text {st }}$ sess., September 19, 2013, accessed on September 8, 2014, http://thomas.loc.gov/video/house-committee/hsvr/38970851.
} 
schedule its own conference calls and briefings, it can augment OCLA's beleaguered workforce and provide increased capacity to improve responsiveness to Congress.

OCLA's centralization of all aspects of VA's congressional engagement resulted in jampacked schedules for its limited staff who assumed a range of responsibilities once performed by subordinate VA components like VHA. This phenomenon was detrimental to OCLA and even more severely impacted VHA. The frenetic pace that resulted from Assistant Secretary Mooney’s internal process changes was ultimately counterproductive because it deprived OCLA staff the time to properly manage their growing workload or develop meaningful relationships with congressional stakeholders. ${ }^{261}$ This lack of “white space” ensured that OCLA staff had insufficient time to review system inputs and analyze political trends. ${ }^{262}$ This centralization compounded the effects throughout VA because no one outside of OCLA retained the authority to engage Congress directly. Without these insights it was impossible to accurately evaluate the political aspect of the Department’s policy environment.

A further decentralization of routine VHA congressional engagements beyond that contemplated in VA Directive 8100 would bring VA into closer alignment with the best practices of other Federal agencies. Even though VHA has an organic congressional affairs office in its Washington headquarters, it is virtually invisible. ${ }^{263}$ A plain reading of the current directive

${ }^{261}$ OCLA's 2014 Federal Employee Viewpoint Survey results offer an interesting window into the climate within that organization at the start of the Phoenix scheduling crisis. 28 OCLA employees took the survey between May 5, 2014 and June 13, 2014. 68\% of employee respondents indicated their intention to leave OCLA within the next year. Only 17.4\% of OCLA staff surveyed positively responded to the statement, "I recommend my organization as a good place to work." This contrasts sharply with the $54.2 \%$ positive response rate to the same question among VA Central Office employees overall.

${ }^{262}$ A good discussion of the dangers inherent in an office "battle rhythm" that allows insufficient unstructured time for strategic level staff to analyze trends, build coordination and observe changes in the environment is contained in Joint Staff J7, Insights and Best Practices Focus Paper, Joint Headquarters Organization, Staff Integration, and Battle Rhythm, 2d ed., July 2013, 9-13.

263 Between 2011 and 2014, VHA congressional affairs personnel were prohibited from sharing their business cards with congressional staff or even identifying the office they worked 
suggests that OCLA personnel will participate in virtually all meetings and calls scheduled with VHACO personnel in Washington, DC regardless of the policy importance of those interactions or the nature of the information discussed. This requirement adds additional layers of coordination and clearance while bounding an expansive organization like VHA to the availability of a handful of OCLA personnel for even the most routine matters. In contrast, most other cabinet departments give wide latitude to subordinate organizations with organic congressional relations personnel. The Department of Homeland Security’s Office of Legislative Affairs “does not perform functions that can/should be performed by operating components that have their own fully functioning congressional or legislative affairs office.”264 The Centers for Disease Control and Prevention, a component of the Department of Health and Human Services, has wide autonomy in its communications with Congress and prides itself on its responsiveness. ${ }^{265}$ With the authority to engage Congress independently like peer organizations within the Federal government, VHA will have the agility to best navigate the current policy environment.

VHA’s Local Leaders Are Vital to Restoring Congress’ Trust

VHA’s vast network of 21 veterans integrated service networks (VISNs) and 152 medical centers (VAMCs) provide an ideal platform for increased congressional engagement in a more coordinated manner. These organizations, led by career SES leaders, provide medical services in all 50 states and the overwhelming majority of congressional districts. While OCLA curtailed

for in the course of their duties. OCLA prescribed this policy. On October 2, 2014, the author conducted a search of the VA and VHA public websites. Neither had any mention of VHA's Office of Congressional and Legislative Affairs (10B3), the largest organic legislative affairs office of any VA component.

${ }^{264}$ Standard Operating Procedures, U.S. Department of Homeland Security Office of Legislative Affairs, February 2010, I.24.

${ }^{265}$ Centers for Disease Control and Prevention, “CDC Washington Office: Bridging Congress and CDC," accessed October 2, 2014, http://cdc.gov/washington/docs/bridgingcongress.pdf. 
virtually all of VHA’s headquarters-level autonomy to engage Congress directly between 2009 and 2014, field facility directors nominally retained their freedom to engage legislators and staff at the local level. This residual local autonomy without the authority from OCLA for independent VHA-level coordination, ensured that VHA's hundreds of locally executed congressional engagements each year were episodic and not nested into a larger national outreach strategy. Individual facility and network directors ably conveyed their local achievements to congressional stakeholders but did not normally tie this to a larger explanation of VHA as a national system. These individual events gave target audiences a glimpse of local VHA efforts but no appreciation of the national system's scope or how it operated. ${ }^{266}$ The lack of a larger understanding of VHA within Congress was evident after the discovery of the 2014 patient scheduling scandal. ${ }^{267}$

Although VISN and VAMC directors never lost their autonomy to engage congressional stakeholders at the local level, OCLA staff from Washington progressively inserted themselves in a host of local, facility specific issues. Since these top-down actions originated outside of VHA, many of VHA’s field leadership bristled at the multiplying layers of coordination and clearance, external to VHA, now required to conduct once routine activities. Responses to Congressional requests that field leaders once provided to staff the same day frequently took weeks when OCLA became involved. OCLA's micromanagement even extended to the approval of the subject matter experts that VISN directors could bring to their meetings with Congress. This centralization by OCLA unintentionally incentivized two general patterns of behavior within VHA at the local level: 1) pervasive "under the radar” coordination of congressional engagements intended to skirt the watchful eyes of OCLA; and 2) a hesitancy of field leaders to engage Congress, even in

266 These are the author's personal observations during the course of 45 months providing consistent congressional affairs support to a portfolio containing six VISNs and 37 VAMCs.

267 This lack of understanding about the larger VHA system extended to HVAC, its primary committee of jurisdiction in the House. Rep. Jim Cooper (D-TN) observed that most HVAC members “don't know how [the VA system] works.” Ryan Grim, "Here’s the Simple Reason Congress Hasn’t Fixed The VA.” 
situations where they clearly should, for fear of triggering time-consuming OCLA information requests or admonishment. ${ }^{268}$ Both of these patterns exacerbated the inherent challenge of ensuring a coordinated and consistent VHA congressional engagement strategy. They also further limited the frequency with which the field shared meaningful congressional information to VA Central Office. James Marsh, a complexity theorist, described this behavior in hierarchical organizations by observing that rule violations due to inconsistent demands will increase as rules multiply and become more complex. This is especially the case in situations where devices for coordination are weak and where independent authorities such as OCLA have the right to impose rules without consideration from the organizations expected to follow them. ${ }^{269}$

To meet Secretary McDonald's charge of reestablishing a culture of openness and trust with Congress, the most logical and low-cost method of advancing a coordinated VHA congressional strategy leverages VHA’s sizeable network of field executives at the VISN and VAMC levels. This can be accomplished through a revitalization of VHA's moribund program of bringing its VISN directors to Washington D.C. semi-annually to meet with legislators and brief Capitol Hill staff on activities within their catchment areas. Prior to the arrival of OCLA Assistant Secretary Mooney in 2009, VHA leadership actively encouraged VISN directors to conduct these activities semiannually. These engagements served the purpose of building a broad network of relationships within Congress between the local facility level and VHA Central Office. They also served as venues to present positive VHA developments at the regional level to harried congressional staff who would not otherwise have awareness of these developments.

Through the 112th and 113th Congresses, the frequency of congressional engagements in Washington among VHA’s VISN directors was very low. The few events scheduled often

268 Between March 2010 and December 2013, the author provided congressional relations support for 6 of VHA's 21 VISNs. These general trends are his direct observations.

269 James G. March, A Primer on Decision Making: How Decisions Happen (New York: The Free Press, 1994), 74. 
depended on the "force of will” of individual VISN directors to navigate a maze of ever-changing clearance and coordination requirements imposed by OCLA. Despite the potential for these visits to create connections between VHA and Members of Congress and build rapport at the subheadquarters level, they were not a priority for OCLA leadership. In some instances, OCLA sent invitations to congressional staff for briefings that required months of advanced coordination with less than 48 hours' notice. ${ }^{270}$

Because of the infrequency of engagements at the VISN level, a disparity emerged in the visibility of various VHA components within Congress. A handful of VISNs persisted with semiannual engagements on Capitol Hill during the 112th and 113th Congresses. In contrast, several networks went more than four years without conducting a single proactive outreach event on Capitol Hill. The high turnover of congressional staff, particularly in the House, demands regular relationship building in recognition of this reality. Because of inconsistent VISN engagement strategies, many Washington-based congressional staff had an extremely limited understanding of VHA's system and few contacts within the organization when the patient scheduling scandal emerged.

Routine congressional outreach activities not tied to Department-level priorities are ideally a VHA-level activity. Providing VHA the autonomy to plan and execute these engagements independently would allow for closer coordination of field outreach efforts while freeing finite OCLA resources to handle priority issues with Department-level sensitivities. Conceptually, VHA autonomy in this domain logically aligns with VHA's existing authorities to conduct outreach communications efforts to individual veterans, VSOs, and the general public.

270 OCLA's limited advance notice to busy congressional staff all but assured low attendance at engagement events designed for VHA field leaders to maximize interaction and build rapport with the Washington, DC based congressional staff serving their network catchment areas. 
If vested with independent congressional outreach authority, VHA could expand its coordinated efforts to include its medical center directors. When VHA leadership names new VAMC directors, individualized communications plans for their announcements are developed. These plans almost always prescribe that the new executives schedule a series of Capitol Hill meetings with the legislators representing their service areas. In the 112th and 113th Congress, these important meetings were almost never conducted and this was largely the result of OCLA's very limited capacity to facilitate them. A prudent delegation of coordination authority to VHA would allow these essential meetings to occur more consistently. The key objective should be the establishment of meaningful relationships built on trust between VAMC directors and Congress before the occurrence of adverse events.

In an uncertain policy environment, VHA's field executives can put a needed local face on a sprawling organization and tie the services provided to individual legislators' constituents to the larger system. A less hierarchical and more frequent flow of information should be VHA's goal and this aligns with recent comments by Secretary McDonald. This will be critically important as VHA faces the 114th Congress. Chairman Miller’s HVAC oversight agenda fostered the emergence of a media narrative of “unaccountable VA executives” being rewarded with lavish bonuses. ${ }^{271}$ This perception has deeply taken root within both houses of Congress and among members of both parties. ${ }^{272}$ Intentionally putting VA field executives in routine contact with elected officials can highlight the fallacy of this narrative’s broad application. The visibility of organizational leaders can also play an essential role as calls for the further privatization of VHA services grow. Local leaders are best postured to showcase the concrete value of their

\footnotetext{
${ }^{271}$ Greg Zaroya and Meghan Hoyer, "VA Seeks to Fire 4 Top Officials; Many Under Investigation Received Bonuses,” USA Today, October 8, 2014, accessed October 10, 2014, http://www.usatoday.com/story/news/nation/2014/10/07/va-officials-fired-removalscandal/16861159/.

272 Joe Davidson, "Democrats' Votes to Strip Some at VA of Civil-Service Rights Show Depth of Scandal,” Washington Post, May 23, 2014, A13.
} 
employees and facilities and tailor those messages in the most salient manner for individual legislators. Political power is more than just high-level interactions between veterans' committee members and high level VA officials. It flows from relationships between other legislators and subordinate VHA field leaders. ${ }^{273}$ In an uncertain policy environment, expanding these connections is a prudent option for VHA. Other Federal health care organizations recognize the inherent value of these transparent and responsive relationships with elected officials. For example, the Army Medical Command actively encourages its field activities to habitually engage the congressional delegations within their catchment area and proactively provide information on issues of potential concern. ${ }^{274}$

VHA Must Cultivate Other Third Party Surrogates to Supplement Declining VSOs Despite occasional policy disagreements, an enduring feature of the veterans' subgovernment was the willingness of VSOs to champion VHA's program and policy priorities while building support for those efforts in Congress. VHA heavily relied on these powerful voices for sustaining stakeholder support and still allocates considerable resources to maintain those relationships. However, as the traditional subgovernment frays, the influence held by large VSOs in Congress dissipates and their incentive to publicly criticize VA grows, as evidenced by the American Legion's recent actions. While VHA faces its most serious crisis in over a generation, it cannot assume the reliable support of the VSOs the way it did during previous controversies. As the nation's largest integrated health care system, VHA must leverage a broader array of surrogates who understand its contributions and can articulate them to target audiences. The most promising advocates for VHA in a changing policy environment are the academic

${ }^{273}$ William G. Weissert and Carol S. Weissert, Governing Health: The Politics of Health Policy, $4^{\text {th }}$ ed., 193.

${ }^{274}$ U.S. Department of the Army, U.S. Army Office of the Surgeon General, Army Medicine 2020 Campaign Plan, March 4, 2013, accessed December 2, 2014, http://armymedicine.mil/Documents/AMEDD_2020_Campaign_Plan_20130325.pdf. 
medical centers and medical schools affiliated with VHA as well as the individual veterans not affiliated with VSOs who utilize its VHA health care.

VA Policy Memorandum \#2, issued in 1946, is an incredibly visionary piece of public policy. It established the legal foundation for VA’s long-standing partnership with medical schools. This document, progressively supplemented by additional statutory authorities, served as the catalyst for VHA's current partnership with 114 of 136 allopathic medical schools and 15 of 26 osteopathic programs. ${ }^{275}$ Approximately, 65\% of U.S. trained physicians and 50\% of U.S. trained psychologists completed some portion of their professional training within the VHA system. ${ }^{276}$ Through these affiliations, thousands of VHA health care providers hold dual VAuniversity faculty appointments with some of the nation's leading academic institutions, to include Harvard, Yale, and Stanford. In 2009, about 70\% of VA’s staff physicians held university faculty appointments. ${ }^{277}$

VHA's academic affiliations and their contribution to innovation across medicine are a little known success story. VA’s new Secretary made several high profile attempts to raise the visibility of these partnerships within Congress and highlight VHA’s key role in training America's future health care leaders. ${ }^{278}$ The Department must quickly expand these long overdue outreach efforts. The rapid destabilization of the veterans' subgovernment in the 113th Congress underscores the urgency of these initiatives.

${ }^{275}$ VHA Office of Academic Affiliations, About Office of Academic Affiliations, accessed September 26, 2014, http://www.va.gov/OAA/resources_about_oaa.asp.

${ }^{276}$ VHA Office of Academic Affiliations, Mission of the Office of Academic Affiliations, accessed September 26, 2014, http://www.va.gov/oaa/oaa_mission.asp.

${ }^{277}$ Kenneth W. Kizer and R. Adams Dudley, "Extreme Makeover: Transformation of the Veterans Health Care System,” 18.5.

${ }^{278}$ Robert A. McDonald, Secretary of Veterans Affairs, Hearing before the House Committee on Veterans Affairs, $113^{\text {th }}$ Cong., 2d sess., September 17, 2014, accessed September 20, 2014, http://www.c-span.org/video/?321497-4/phoenix-va-inspector-generals-report-panel-2. 
The benefits of VHA's academic affiliations and their contributions to medical research and training extend far beyond the affiliated institutions themselves. Academic medical centers average over 6,000 full time employees and often rank among the largest employers in their respective regions. ${ }^{279}$ These centers are anchors within their communities and have considerable influence with elected officials and the media. In an increasingly uncertain policy environment, they are credible third party surrogates to communicate VHA's unique role to legislators and augment the VSOs by communicating a complementary message to an expanded audience. As a key part of the emerging "knowledge economy," academic medical centers have the potential to increase VHA's influence and perceived value beyond the confines of its traditional subgovernment to a larger congressional and public policy audience.

Since taking the helm at VA in August 2014, Secretary McDonald consistently engaged leaders of VA’s academic affiliates to include Duke University and The University of Pennsylvania. ${ }^{280}$ VHA's congressional engagement strategy at both the headquarters and local levels can amplify these nascent efforts. For example, VHA can consistently incorporate tailored information about these affiliations into its interactions with Congress. This simple change would raise congressional awareness of VHA's strong reputation within academic medicine and provide trusted and influential third parties to validate the quality of VA health care.

If calls for the further privatization of VHA services increase as expected, the legitimacy and reputation of its academic affiliates may prove even more influential in some regions than the VSOs. Examples where this may be the case include areas with rapidly declining veteran populations such as the New York City region and New England, locations where the biomedical and technology sectors are central to the local economy, and regions represented by legislators

${ }^{279}$ Association of Academic Health Centers, Academic Health Centers: Creating the Knowledge Economy, April 2009, accessed September 26, 2014, http://www.aahcdc.org/portals/0/pdf/fg_ahc_creating_the_knowlege_economy_04-09.pdf.

${ }^{280}$ Robert A. McDonald, Secretary of Veterans Affairs, Hearing before the House Committee on Veterans Affairs, 113th Cong., 2d sess., September 17, 2014. 
reflexively opposed to "big government," but supportive of academic medicine and its economic contributions to communities. VHA's long-standing affiliations with world-class institutions enhance their training and research missions while underscoring the value of a robust VHA. This may appeal to a wider ideological spectrum than VA's traditional engagement strategies developed in an earlier era dominated by the closed but powerful veterans’ subgovernment. If advocacy for VHA privatization continues to be backed by corporate health care dollars and political fundraising networks, the institutional clout of VA academic affiliates provides an influential alternative perspective to policy makers. ${ }^{281}$ Furthermore, by coming from a perspective outside the traditional subgovernment, academic affiliates would be less beholden to the HVAC and SVAC leadership and theoretically better positioned to offer dissenting opinions if needed.

In addition to its academic affiliates, individual veterans enrolled in VA health care have great potential as VHA surrogates in an unstable policy environment. The influence of government agencies in the policy arena can partially derive from political astuteness or the ability to garner support from the recipients or beneficiaries of the agency’s programs. ${ }^{282}$ In the traditional subgovernment model, the large VSOs effectively used their impressive membership numbers in this role and VA relied on their influence to amplify its message to individual veterans. As VSO influence unevenly diminishes, VHA might consider using its routine interactions with individual veterans to directly showcase the unique aspects of its health care

${ }^{281}$ Ranked by industry, health care organizations consistently rank at or near the top in congressional contributions. Their great influence and reputation for aggressive lobbying to advance their policy preferences makes it likely they will increasingly focus on veterans' health care, especially if trends suggest the increased privatization of care. The lobbying expenditures around the passage of P.L. 113-146 (discussed previously) may be a harbinger of the future. William G. Weissert and Carol S. Weissert, Governing Health: The Politics of Health Policy, $4^{\text {th }}$ ed. (Baltimore: Johns Hopkins University Press, 2012), 174.

${ }^{282}$ William G. Weissert and Carol S. Weissert, Governing Health: The Politics of Health Policy, $4^{\text {th }}$ ed., 192. 
system. ${ }^{283}$ This would incorporate direct-to-veteran communications into the existing VSOcentric engagement strategy. ${ }^{284}$

A more ambitious direct-to-veteran engagement strategy could also build on the recent efforts of Secretary McDonald to hold town hall meetings for veterans at all VHA facilities. These events hold great promise because they allow veterans to directly bring their concerns or praise in an open forum that allows dialogue with senior leadership. VA invites outside stakeholders such as the media and congressional staff to participate and this fosters an environment to highlight VHA accomplishments and address veteran concerns. Beyond the veterans themselves, it provides the other stakeholders in attendance a deeper context to appreciate VHA and its relationship with patients beyond the contentious narrative established by HVAC. This enhanced interface also accomplishes Secretary McDonald's stated goal of “opening the VA culture.”285

\section{Conclusion}

${ }^{283}$ The author is not advocating an expensive advertising campaign, rather using passive measures in VHA facilities to raise veteran awareness about the system they utilize, its research and education contributions, quality measures, and cost containment efforts. These could appear on existing monitors in patient waiting areas or as table tents in waiting areas or hospital canteens.

${ }^{284}$ VA long relied on VSOs to conduct direct-to-veteran messaging about its programs and services. This traditional approach did not fully consider the significant number of veterans who were not VSO members nor the growing disparity of VSO strength in different areas of the country. Secretary McDonald's recent announcement that VA will establish a national network of regional veterans advisory councils suggests that VA leaders recognize the importance of a new VA-facilitated engagement strategy for veterans. Josh Hicks, "VA Chief Unveils Restructuring Plan for Troubled Agency," Washington Post, November 10, 2014, accessed, November 10, 2014, http://www.washingtonpost.com/blogs/federal-eye/wp/2014/11/10/va-chief-unveilsrestructuring-plan-for-troubled-agency/.

${ }^{285}$ Robert A. McDonald, “Transcript: Secretary McDonald Press Conference Outlining The Road To Veterans Day” (press conference, Washington DC, September 8, 2014), accessed September 19, 2014, http://www.va.gov/opa/pressrel/pressrelease.cfm?id=2622 
The destabilization of the veterans’ policy subgovernment will continue and it is unlikely to revert to the closed system that existed in the decades following World War II because the unique historical factors that formed it cannot again be replicated. VHA's immersion into the modern congressional arena strips it of the special status it enjoyed in an era of bipartisan policy consensus and assured by the protective influence of powerful VSOs. This uncertain policy environment demands that VHA recognize the emergent trends of destabilization and take several long overdue actions to react to a fundamentally changed policy environment.

The structural changes in the House since the 1990s appear to be enduring and vary little despite which party has control of chamber. ${ }^{286}$ Since 1979 , the Senate grew progressively more polarized and it is now almost as polarized as the House. ${ }^{287}$ VA cannot change this intractable political environment; it can only attempt to mitigate its most damaging effects. Dr. Norman Ornstein, the dean of political pundits, ${ }^{288}$ observed that if the larger political forces in Congress are intent on blocking or obstructing a veterans' legislative initiative, no amount of outreach by VA can overcome it. ${ }^{289}$ Ornstein notes the irony in this phenomenon as Congress is partially responsible for creating the access conditions within VA health care that contributed to the patient scheduling scandal because legislators expanded eligibility and available services without commensurate resource authorizations. A new congressional engagement approach can help VHA increase the general awareness of its programs, broaden the audience it communicates with, and more effectively respond to an increasingly aggressive oversight agenda.

${ }^{286}$ When Democrats regained control of the House in 2006, many observers were surprised when then-Speaker Nancy Pelosi quite unexpectedly retained many of the Gingrich-era rules. Since both parties have now institutionally ratified these policies they are likely enduring features of House governance. Richard Pildes, "Why the Center Does Not Hold: The Causes of Hyperpolarized Democracy in America,” 320.

${ }^{287}$ Sean Theriault, The Gingrich Senators, 10, 36.

${ }^{288}$ Ibid., 5.

${ }^{289}$ Dr. Norman Ornstein, telephone conversation with the author, September 3, 2014. 
Events in the 112th and 113th Congresses show that VHA is quite vulnerable in a policy environment where it is the subject of partisan scrutiny and its shortcomings are linked to larger political disputes beyond the realm of veterans' health care. As a Federal agency, problems that develop at its facilities often become a matter of public record as stipulated by the Freedom of Information Act (FOIA). Since health care quality disclosures in the private sector are far less common, this places VHA at a severe disadvantage because it feeds an erroneous perception of poor quality in both Congress and the general public. ${ }^{290}$ From a public relations standpoint, this puts VA in a very challenging position. Senator Bernard Sanders (I-VT) explained this dynamic by observing that VA treats an enormous number of patients and that even if $95 \%$ of them reported receiving excellent care (an unrealistically high satisfaction rate for a health care organization), there would still be a significant number of unsatisfied patients. ${ }^{291}$ If someone actively looks for adverse medical outcomes in the nation's largest integrated health care system, they will find them. VHA must recognize this current environment and conduct sustained outreach to the widest array of congressional stakeholders. It must also utilize additional surrogates beyond the traditional VSOs to amplify these efforts. Simply put, increased transparency may be the best policy response to these structural challenges. While transparency can expose vulnerabilities, they are generally easier to improve when publicly acknowledged. ${ }^{292}$

It is highly unlikely that the traditional VSOs will ever regain the size or influence they enjoyed during the six decades following World War II. The size, quality, and scope of VHA are

${ }^{290}$ Said C. Ibrahim, David S. Macpherson, and Michael E. Moreland, "VA Healthcare System: A Potential Model for a National Plan,” in The Praeger Handbook of Veterans' Health: History, Challenges, Issues, and Developments, ed. Thomas W. Miller, vol. 4. Future Directions in Veterans' Healthcare (Santa Barbara, CA: Praeger, 2012), 182.

${ }^{291}$ Senator Bernard Sanders (I-VT), interview by Greta Wodele Brawner, C-SPAN Newsmakers, May 22, 2014, accessed August 7, 2014, http://www.c-span.org/video/?3195221/newsmakers-sen-bernie-sanders-ivt.

${ }^{292}$ Kenneth W. Kizer and Ashish Jha, "Restoring Trust in VA Health Care,” New England Journal of Medicine 371, no. 4 (July 24, 2014): 295-297. 
a testament to the past strengths of these groups and they still remain highly a key element of the veterans’ subgovernment. However, larger demographic trends in the national veteran population and structural changes in advocacy organizations generally have changed the fundraising and membership environment for VSOs. The rise of narrow, professionally led organizations such as IAVA, WWP, and CVA have disrupted the traditionally collective VSO culture and facilitated the increased influence of corporate dollars and lobbying within veterans’ policymaking. This profound change further reorders a once stable subgovernment with clear implications for VHA. Despite their perceived flaws, traditional VSOs were deliberately structured by their founders to influence all levels of government and involve individual veterans and communities in those efforts. ${ }^{293}$ Unlike the newer groups, traditional VSOs have a long-standing and unique dual role within the veterans’ subgovernment as service providers to veterans and organized interests on their behalf. ${ }^{294}$ This reality bound the VSOs very tightly to the other elements of the subgovernment and served as an influential bridge between VA and Congress. In contrast, the new veterans groups do not have this dual role and are not as heavily invested in the structure or scope of VHA as a unique, government-owned and government-operated health care system.

The congressional and media focus on VHA following the patient scheduling crisis will shape the public's view of VHA for at least the remainder of the Obama administration and likely beyond. In a span of six weeks, the public reputation of the nation's largest integrated health care system, long held as a national model for quality, was in tatters. ${ }^{295}$ The political environment in

293 Theda Skocpol, "Unravelling from Above.”

${ }^{294}$ Lael R. Kaiser and Susan M. Miller, "The Impact of Organizational Interests on Eligibility Determination: The Case of Veterans' Disability Compensation,” Journal of Public Administration Research and Theory 20, no. 2 (2010), 509.

295 The dramatic and immediate impact the patient scheduling scandal had on public perceptions of VHA was evident in a USA Today poll conducted between May 29 and June 1, 2014 - the week of Secretary Shinseki's resignation. Only one in five respondents rated the job the government does in providing veterans with medical care as "excellent" or "good." This was about half the number who provided similar positive responses during a 2011 Pew survey. Fully seven in ten respondents to the USA Today survey categorized VA care as "fair" or poor." Susan 
2014 was so toxic that even VHA's champions within Congress were hesitant to come to its defense publicly. ${ }^{296}$ This is unfortunate because neither of the prevalent narratives following the scheduling crisis, governmental incompetence or lack of funding, actually captured the complexities or dimensions of a much larger problem that impacts American health care broadly. ${ }^{297}$ Whatever its shortcomings, VHA remains an innovator within the health care arena ${ }^{298}$ and enjoys consistently high satisfaction ratings among its veteran patients. ${ }^{299}$

Going forward, VHA must navigate this uncertain policy environment while receiving the most intense and sustained congressional scrutiny in its history. Compounding the challenges, seismic upheavals are underway within its long-standing advocacy coalitions. In retrospect, it is clear that VA as a department should have identified destabilizing trends within the veterans' subgovernment and adapted its engagement strategies long before the Phoenix scandal captured the nation's attention. Instead of revising its policies and procedures designed for a fundamentally different policy environment, VA tightened its reliance on them. A respected political commentator observed that VA "utterly failed” to shape a larger political message or rationale for its important programs in the 113th Congress. ${ }^{300}$ Its outreach to stakeholders and responsiveness to Congress were completely inadequate in an era where even the most traditionally sacrosanct

Page, “Poll: Confidence in Vets’ Care Hits Low,” USA Today, June 3, 2014, 5A.

296 James Kitfield, "Behind Eric Shinseki’s Downfall.”

${ }^{297}$ Kenneth W. Kizer, interview with Arun Rath, NPR's All Things Considered, June 8, 2014, accessed June 14, 2014, http://www.npr.org/2014/06/08/320077411/was-there-incentive-atva-for-behavior-that-created-scandal.

${ }^{298}$ Robert A. McDonald, "VA is Critical to Medicine and Vets," Baltimore Sun, October 23, 2014, accessed October 24, 2014, http://www.baltimoresun.com/news/opinion/oped/bs-ed-vasecretary-20141023-story.html.

${ }^{299}$ Patricia Kime, “Patients Rate VA Medical Centers High for Satisfaction,” Army Times, April 16, 2014, accessed September 2, 2014, http://www.armytimes.com/article/20140416/BENEFITS04/304160035/Patients-rate-VAmedical-centers-high-satisfaction.

${ }^{300}$ Dr. Norman Ornstein, telephone conversation with the author, September 3, 2014. 
government programs have come under attack. ${ }^{301}$ It appears that the multi-generational legacy of the veterans' subgovernment “iron triangle” was so enduring and so central to VA's organizational identity that destabilizing events clearly conflicted with powerful and tacit mental models held by many of its leaders. ${ }^{302}$

In his first months as VA Secretary, Robert McDonald established a shared vision for the Department. He further recognized the need for VA to reorient its relationship with elected officials and veterans as well as its internal organizational culture. As a complex organization with four distinct primary missions, this will prove to be a challenging, but essential effort. ${ }^{303}$ To achieve this pivot, VA must become less hierarchical and decentralize decision making in order to increase agility, responsiveness, and organizational resilience. ${ }^{304}$ However, there is a danger that many within the organization will view the new vision embraced by the Secretary as transitory and it will fail to galvanize VA. This can happen if subordinate leaders see the patient scheduling crisis and the passage of P.L. 113-146 as the galvanizing events for the institution, rather than the fundamental need for a change in culture articulated by Secretary McDonald. VHA's own experience over the past 15 years provides a basis for these concerns. As Under Secretary for Health, Dr. Kenneth Kizer revolutionized VHA by decentralizing its processes, empowering subordinate leaders, and implementing an industry-leading performance monitoring system. Despite his personal leadership and success in transforming VHA into a national leader in

${ }^{301}$ Kevin Boyle, "Twenty-Nine Helmets: Government Power and the Promise of Security," To Promote the General Welfare: The Case for Big Government, ed. Steven Conn (New York: Oxford University Press, 2012), 100.

${ }^{302}$ Peter M. Senge, The Fifth Discipline: The Art \& Practice of The Learning Organization (New York: Doubleday, 1990), 8.

${ }^{303}$ Kenneth W. Kizer and R. Adams Dudley, "Extreme Makeover: Transformation of the Veterans Health Care System,” 18.4.

${ }^{304}$ Robert A. McDonald, "Transcript: Secretary McDonald Press Conference Outlining The Road To Veterans Day.” 
health care quality, a leadership culture of insularity and top down management gradually reemerged after his departure. ${ }^{305}$

In a policy environment marked by uncertainty, the Veterans Health Administration must transform its external engagement practices as thoroughly as it revamped its health care delivery model in the 1990s. As a learning organization with a workforce committed to excellence in health care, VHA is capable of accomplishing the necessary "shift of mind" to recognize the emergent state of the veterans subgovernment and reinvent its role within it. ${ }^{306}$ The seismic and lasting changes currently underway in what was once considered among the most stable domestic policy arenas require a shared vision for VHA in an unfamiliar and evolving environment radically different from the one most of its leadership built their careers in. These cultural and institutional changes within VA will not be easy, but they are essential to meet the larger external forces inexorably reshaping the veterans’ subgovernment.

${ }^{305}$ Kenneth W. Kizer and Ashish Jha, "Restoring Trust in VA Health Care.”

${ }^{306}$ Peter M. Senge, The Fifth Discipline: The Art \& Practice of the Learning Organization, 13-14. 


\section{Bibliography}

Abramowitz, Alan I. The Disappearing Center: Engaged Citizens, Polarization, and American Democracy. New Haven: Yale University Press, 2010.

Axelrod, Robert, and Michael D. Cohen. Harnessing Complexity: Organizational Implications of a Scientific Frontier. New York: Basic Books, 2000.

Barone, Michael, and Chuck McCutcheon. The Almanac of American Politics 2014. Chicago: The University of Chicago Press, 2013.

Berry, Jeffrey M., and Clyde Wilcox. The Interest Group Society. $5^{\text {th }}$ ed. New York: Pearson Longman, 2009.

Bimber, Bruce, Andrew J. Flanagin and Cynthia J. Stohl. Collective Action in Organizations: Interaction and Engagement in an Era of Technological Change. Cambridge: Cambridge University Press, 2012.

Binder, Sarah A. Stalemate: Causes and Consequences of Legislative Gridlock. Washington, DC: Brookings Institution Press, 2003.

Brownlee, Shannon. Overtreated: Why Too Much Medicine is Making Us Sicker and Poorer. London: Bloomsbury, 2007.

Campbell, Alec. “The Sociopolitical Origins of the American Legion.” Theory \& Society 39, no. 1 (2010): 1-24.

. "The Invisible Welfare State: Establishing the Phenomenon of Twentieth Century

Veteran's Benefits.” Journal of Political and Military Sociology 32, no. 2 (Winter 2004): 249-267.

Cigler, Allan J., and Burdett A. Loomis, eds. Interest Group Politics. $8^{\text {th }}$ ed. Washington, DC: CQ Press, 2012.

Congressional Quarterly Almanac 1995, $104^{\text {th }}$ Congress, $1^{\text {st }}$ Session. Vol. LI. Washington: Congressional Quarterly, 1996.

Congressional Quarterly Almanac 1996, $104^{\text {th }}$ Congress, $2^{\text {nd }}$ Session. Vol. LII. Washington: Congressional Quarterly, 1997.

Congressional Quarterly Almanac 1999, $106^{\text {th }}$ Congress, $1^{\text {st }}$ Session. Vol. LV. Washington: Congressional Quarterly, 2000.

Conn, Steven, ed. To Promote the General Welfare: The Case for Big Government. New York: Oxford University Press, 2012.

Cox, Gary W., and Matthew D. McCubbins. Legislative Leviathan: Party Government in the House. Berkeley, CA: University of California Press, 2003.

Daniels, Brian. “Changing Veteran Status in the Post-September 11 Period.” Xavier Journal of Politics 2, no. 1 (Fall 2011): 33-45.

deHaven-Smith, Lance., and Carl E. Van Horn. "Subgovernment Conflict in Public Policy." Policy Studies Journal 12, no. 4 (June 1984): 627-642.

Dellinger, Daniel M. “As Stewards of the Legion’s Future.” American Legion, September 2014. “The Measure of American Legion Impact.” American Legion, July 2014.

Denhardt, Robert B., Janet V. Denhardt and Tara A. Blanc, Public Administration: An Action Orientation. $7^{\text {th }}$ ed. Boston: Wadsworth Cengage Learning, 2014. 
Department of Veterans Affairs. Office of Inspector General. Veterans Health Administration Review of Alleged Patient Deaths, Patient Wait Times, and Scheduling Practices at the Phoenix VA Health Care System. August 26, 2014.

DeShazo, J.R., and Jody Freeman. "The Congressional Competition to Control Delegated Power.” Texas Law Review 81 (2002-2003):1443-1518.

Dollman, Everett C. Pure Strategy: Power and Principle in the Space and Information Age. London: Frank Cass, 2005.

Dyhouse, Tim. “Where Will VFW Be in Five Years?” VFW Magazine, February 2013.

Executive Office of the President. Issues Impacting Access to Timely Care at VA Medical Facilities. June 27, 2014.

Feinstein, Brian D. "Supplement to: Congressional Control of Administrative Agencies,” Social Science Research Network Working Paper Series, July 31, 2013.

Fiorina, Morris P., with Samuel J. Abrams. Disconnect: The Breakdown of Representation in American Politics. Norman: University of Oklahoma Press, 2009.

Frank, Thomas. The Wrecking Crew. New York: Metropolitan Books, 2008.

Frantz, Janet. “The Battle Over America’s VA Hospitals.” Politics \& Policy 30, no. 3 (September 2002): 524-550.

Frantzich, Stephen E., and Claude Berube. Congress: Games and Strategies. $4^{\text {th }}$ ed. Lanham, MD: Roman and Littlefield, 2010.

Gharajedaghi, Jamshid. Systems Thinking: Managing Chaos and Complexity: A Platform for Designing Business Architecture. 2d ed. Burlington, MA: Butterworth-Heinemann, 2006.

Hamilton, James, Robert F. Muse and Kevin R. Amer. "Congressional Investigations: Politics and Process.” American Criminal Law Review, 44, no. 3 (2010): 1117-1176.

Hrywna, Mark. “New Veterans’ Charities Race Past Broader Sector.” NonProfit Times, December 1, 2013.

Jervis, Robert. System Effects: Complexity in Political and Social Life. Princeton, NJ: Princeton University Press, 1997.

John, Peter. "Is There Life After Policy Streams, Advocacy Coalitions, and Punctuations: Using Evolitionary Theory to Explain Policy Change?” Policy Studies Journal 31, no. 4 (2003): 481-498.

Kaiser, Lael R., and Susan M. Miller. "The Impact of Organized Interests on Eligibility Determination: The Case of Veterans’ Disability Compensation.” Journal of Public Administration Research and Theory 20, no. 2 (2010): 505-531.

Keller, Bill. "How a Unique Lobby Force Protects Over \$21 Billion in Vast Veterans’ Programs.” Congressional Quarterly, June 14, 1980.

Kessler, Glenn. "Overblown Claims of Deaths and Waiting Times at the VA.” Washington Post, September 2, 2014.

Kizer, Kenneth W., and R. Adams Dudley, "Extreme Makeover: Transformation of the Veterans Health Care System.” Annual Review of Public Health 30 (2009): 18.1-18.27.

Kizer, Kenneth W., and Ashish K. Jha, "Restoring Trust in VA Health Care.” New England Journal of Medicine 371, no. 4 (July 24, 2014): 295-297. 
Knownes, Anthony J., Interest Groups in American Politics: Pressure and Power. 2d ed. New York: Routledge, 2013.

Kollman, Ken. "Inviting Friends to Lobby: Interest Groups, Ideological Bias, and Congressional Committees.” American Journal of Political Science 41, no. 2 (April 1997): 519-544.

Korb, Lawrence J., Sean M. Duggan, Peter M. Juul, and Max A. Bergmann. Serving America's Veterans: A Reference Handbook. Santa Barbara, CA: ABC-CLIO, 2009.

Kriner, Douglas. “Can Enhanced Oversight Repair ‘The Broken Branch?’” Boston University Law Review 89 (2009): 765-793.

Leon, Richard J. “Congressional Investigations: Are Partisan Politics Undermining Our Vital Institutions?” Suffolk University Law Review XXXI (1998): 825-836.

Light, Paul. C., Forging Legislation. New York: W.W. Norton \& Company, 1992.

Longman, Phillip. Best Care Anywhere: Why VA Health Care Would Work Better for Everyone. $3^{\text {rd }}$ ed. San Francisco: Berrett-Koehler Publishers, 2012.

Loomis, Burdett A., and Wendy J. Schiller. The Contemporary Congress. $5^{\text {th }}$ ed. Boston: Thomson Wadsworth, 2006.

Loomis, Burdett A., interview by Stephen K. Trynosky, Lawrence, KS, February 12, 2014.

Mandeles, Mark D. “Imposing Order on Chaos: Establishing JTF Headquarters.” Joint Center for Operational Analysis Journal XII, no. 2 (Summer 2010): 21-32.

Mann, Thomas E., and Norman J. Ornstein. It's Even Worse Than It Looks: How the American Constitutional System Collided with the New Politics of Extremism. New York: Basic Books, 2012.

The Broken Branch: How Congress is Failing America and How to Get It Back on Track. Oxford: Oxford University Press, 2006.

Marsh, James G. A Primer On Decision Making: How Decisions Happen. New York: The Free Press, 1994.

Masci, David. “Cuts All Over - Except the VA.” Congressional Quarterly, July 15, 1995.

McCubbins, Matthew D., and Thomas Schwartz. "Congressional Oversight Overlooked: Police Patrols Versus Fire Alarms.” American Journal of Political Science 28, no. 1 (February 1984): 165-179.

Ogden, Daniel M. How National Policy Is Made. $4^{\text {th }}$ ed. D.M. Ogden, Jr., 1992

O’Keefe, Ed. “Problems at VA Still in Focus on Capitol Hill.” Washington Post, June 23, 2014.

Olsen, Ken. “VA’s Series of Unfortunate Events.” American Legion, July 2014.

Ornstein, Norman. “Specter of Gilded Age Tarnishes VA Reforms.” National Journal, July 9, 2014.

Ortiz, Stephen R., ed. Veterans' Policies, Veterans Politics: New Perspectives on Veterans in the Modern United States. Gainesville, FL: University Press of Florida, 2012.

Parker, David C.W., and Matthew Dull, "Divided We Quarrel: The Politics of Congressional Investigations, 1947-2004,” Legislative Studies Quarterly 34, no. 3 (August 2009): 319345.

Philpott, Tom. “Report Blasts VHA’s ‘Corrosive Culture.’” American Legion. September 2014. 
Pildes, Richard. "Why the Center Does Not Hold: The Causes of Hyperpolarized Democracy in America.” California Law Review 99, no. 2 (April 2011): 273-332.

Praeger Handbook of Veterans' Health: History, Challenges, Issues, and Developments. Edited by Thomas W. Miller. 4 vols. Santa Barbara, CA: Praeger, 2012.

Rohde, David W. "Parties and Committees in the House: Member Motivations, Issues, and Institutional Arrangements.” Legislative Studies Quarterly 19, no. 3 (August 1994): 341359.

Sarbanes, John P., and Raymond O’Mara III. “Foreword: Elections in America.” Harvard Law \& Policy Review 8, no. 1 (Winter 2014): 1-20.

Schiller, Nicole. “Examining Veterans’ Interest Groups: Understanding Success through Interest Group Ratings.” Res Publica - Journal of Undergraduate Research 13, no. 1 (2008):6476.

Senge, Peter M. The Fifth Discipline: The Art \& Practice of the Learning Organization. New York: Doubleday, 1990.

Shane, Leo. "IAVA Attracts the Spotlight - and Detractors.” Stars and Stripes, September 5, 2012.

Sinclair, Barbara. Unorthodox Lawmaking: New Legislative Processes in the U.S. Congress. $4^{\text {th }}$ ed. Washington, DC: CQ Press, 2012.

Skocpol, Theda. Diminished Democracy: From Membership to Management in American Civic Life. Norman, OK: University of Oklahoma Press, 2003.

“Unravelling From Above.” American Prospect, March-April 1996.

“Associations Without Members.” American Prospect, December 19, 2001.

Tarsi, Melinda R. "From Rights to Repayment: The Framing of the Post-9/11 GI Bill.” Paper prepared for the annual meeting of the American Political Science Association, September 1-4, 2011.

Theriault, Sean M. Party Polarization In Congress, New York: Cambridge University Press, 2008.

The Gingrich Senators. Oxford: Oxford University Press, 2013.

Turabian, Kate L. A Manual for Writers of Research Papers, Theses, and Dissertations. $7^{\text {th }}$ ed. Chicago: University of Chicago Press, 2007.

Washington, La Trice M. The Veterans Millennium Health Care Act of 1999: A Case Study of Role Orientations of Legislators, the President, and Interest Groups. Lanham, MD: University Press of America, 2003.

Watson, Tom. "Vietnam Vets a Growing Force in Congress,” Congressional Quarterly, September 12, 1987.

“Veterans’ Lobbies Showing New Unity on Hill,” Congressional Quarterly, September 12, 1987.

Weissert, William G., and Carol S. Weissert. Governing Health: The Politics of Health Policy. $4^{\text {th }}$ ed. Baltimore: Johns Hopkins University Press, 2012.

Wilson, James Q., John J. DiIulio, and Meena Bose. American Government: Brief Version. $11^{\text {th }}$ ed. Boston: Cengage Learning, 2013. 
